\title{
Peroxisome Proliferator-Activated Receptors as Molecular Links between Caloric Restriction and Circadian Rhythm
}

\author{
Kalina Duszka ${ }^{1, *(\mathbb{D})}$ and Walter Wahli ${ }^{2,3,4}$ (D) \\ 1 Department of Nutritional Sciences, University of Vienna, 1090 Vienna, Austria \\ 2 Center for Integrative Genomics, University of Lausanne, Le Génopode, CH-1015 Lausanne, Switzerland; \\ Walter.Wahli@unil.ch \\ 3 Lee Kong Chian School of Medicine, Nanyang Technological University Singapore, Clinical Sciences \\ Building, 11 Mandalay Road, Singapore 308232, Singapore \\ 4 Toxalim, INRAE, Chemin de Tournefeuille 180, F-31027 Toulouse, France \\ * Correspondence: kalina.duszka@univie.ac.at; Tel.: +43-1-4277-54992
}

Received: 17 October 2020; Accepted: 9 November 2020; Published: 12 November 2020

\begin{abstract}
The circadian rhythm plays a chief role in the adaptation of all bodily processes to internal and environmental changes on the daily basis. Next to light/dark phases, feeding patterns constitute the most essential element entraining daily oscillations, and therefore, timely and appropriate restrictive diets have a great capacity to restore the circadian rhythm. One of the restrictive nutritional approaches, caloric restriction (CR) achieves stunning results in extending health span and life span via coordinated changes in multiple biological functions from the molecular, cellular, to the whole-body levels. The main molecular pathways affected by CR include mTOR, insulin signaling, AMPK, and sirtuins. Members of the family of nuclear receptors, the three peroxisome proliferator-activated receptors (PPARs), PPAR $\alpha, \operatorname{PPAR} \beta / \delta$, and PPAR $\gamma$ take part in the modulation of these pathways. In this non-systematic review, we describe the molecular interconnection between circadian rhythm, CR-associated pathways, and PPARs. Further, we identify a link between circadian rhythm and the outcomes of CR on the whole-body level including oxidative stress, inflammation, and aging. Since PPARs contribute to many changes triggered by CR, we discuss the potential involvement of PPARs in bridging CR and circadian rhythm.
\end{abstract}

Keywords: caloric restriction; nuclear receptors; circadian rhythm; metabolism

\section{Introduction}

The circadian (circa-approximately; dian-day) clock is a system conserved from cyanobacteria to humans, which generates internal oscillations with a near $24 \mathrm{~h}$ periodicity coordinating bodily processes in an anticipatory fashion. In mammals, the circadian clock governs nearly all aspects of physiology and behavior, including hepatic metabolism, cardiovascular activity, gastrointestinal tract activity, blood pressure, endocrine secretions, body temperature, renal function, and sleep-wake rhythm [1-4]. The adaptation to the recurring external and internal changes results in diurnal activity cycles and the anticipation of such changes constitutes a survival advantage to an organism capable of adjusting its molecular, physiological, and behavioral pathways $[1,2,5]$.

The expression of circadian genes oscillates in an organ-dependent manner, with roughly 9-20\% of all transcripts, which may differ from one cell or tissue to another, exhibiting a rhythmic pattern [6-9]. In fact, some studies report up to $43 \%$ of protein-coding genes showing circadian oscillations [10]. Disruption of the circadian coordination either by mutations in circadian clock genes or environmental factors interferes with metabolic processes and creates hormone imbalance, 
which increases the risk of several diseases, including various cancers, neurological and metabolic disorders, cardiovascular diseases, psychological and sleep disorders, all in all resulting in reduced longevity [2,11-17]. Forcing nocturnal animals to be active or to feed during the daytime, leads to obesity and metabolic disturbances $[18,19]$. Similarly, introducing a dim light in the dark phase shifts the time of food intake that results in dysmetabolism and increased body mass in wild-type (WT) mice [18]. In humans, circadian misalignment induces a reduction of daily energy expenditure by approximately 12-16\% [20], decreases leptin and peptide YY levels which signal satiety, elevates postprandial glucose and insulin, and increases mean arterial pressure [21]. Metabolic and feeding cues act as potent zeitgebers for peripheral circadian clocks [5,22-24] and a large number of hepatic rhythmic transcripts under ad libitum feeding conditions are driven by the daily pattern in food intake. Nearly $10 \%$ of the hepatic transcriptome oscillations are under the control of the cell-autonomous circadian clock and feeding schedule. Out of nearly 3000 of hepatic transcripts oscillating daily, fasting suppresses the oscillation of $>80 \%$ of them [25]. Refeeding after fasting triggers changes in the hepatic expression of the core circadian proteins including Period 1 and 2 (PER1, PER2), differentially expressed in chondrocytes 1 (DEC1 or BHLHE40), and REV-ERB $\alpha$ in rats and mice within $30 \mathrm{~min}$ to $1 \mathrm{~h}[26,27]$. Daytime feeding in naturally nocturnal mice leads to a shift in the phase of expression of $>84 \%$ transcripts of the clock components and other rhythmic metabolic factors, and $>73 \%$ of the oscillating genes increase their oscillation amplitude [25]. However, granting food access only in the nocturnal phase can induce WT-like anticipatory activity, respiratory exchange ratio (RER) changes, and gene expression rhythmicity in cryptochrome (Cry) deficient mice [25]. Therefore, besides the functional circadian clock, the availability of food, and the temporal pattern of feeding plays an essential role in determining daily rhythms. Similarly, time-restricted feeding (TRF) of mice promotes natural feeding rhythms and restores oscillations of the circadian clock and expression of their target genes, which rhythmicity is dampened by a high-fat diet (HFD) [28,29]. HFD is known to affect the central and peripheral circadian clocks; it disrupts circadian rhythms of the locomotor and feeding activities and leads to metabolic dysfunction due to the reduction of oscillation amplitude of the circadian clock and expression of the clock-controlled gene in the liver [30]. TRF besides restoring liver rhythms in circadian clock gene expression also normalizes metabolism and reduces obesity-associated inflammation without reducing food intake [28]. However, it is controversial whether similar metabolic benefits can be obtained without synchronization of the peripheral and central clocks namely when the mice are restricted to feed only during the light versus only the dark phase [29,31,32]. Similarly to animal studies, restriction of the eating window to day time in overweight people, without limiting energy intake, results in a reduction in body weight [33].

Therefore, diets, particularly restrictive diets that limit time or amount of consumption, have the capacity to adjust the expression of peripheral circadian genes. Resetting of circadian rhythms and introducing synchrony of the central and peripheral clocks can lead to increased longevity and wellbeing. Moreover, the circadian clock, as a vital factor in longevity, metabolism, and regulation of multiple physiological processes likely contributes to the beneficial effects of restrictive diets in mammals. In this non-systematic review, we will summarize the interconnection between one of the restrictive diets, caloric restriction (CR), and the circadian rhythm at the molecular and whole-organism level. Furthermore, we will present evidence for and potential of the nuclear receptors peroxisome proliferator-activated receptors (PPARs) in bridging CR and circadian processes.

\section{Molecular Background of the Circadian Clock}

In mammals, every tissue or physiological function exhibits diurnal oscillations. The central circadian pacemaker clock is located in the suprachiasmatic nucleus (SCN) of the brain. More precisely it resides in a bilateral group of neurons found in the anterior hypothalamus [2]. The master clock is entrained by light through the retinohypothalamic tract (RHT) whose role is to synchronize the internal clock ticking to the external day/night cycle. The perceived light leads to activation and synchronization of SCN neurons by an intrinsic SCN factor called vasoactive intestinal polypeptide (VIP) [34]. 
Then, these SCN neurons send signals to peripheral oscillators to prevent the dampening of circadian rhythms in various tissues. The signal distribution involves autonomic innervation or circulating humoral factors [2,35] such as transforming growth factor $\alpha$ (TGF $\alpha$ ) [36], glucocorticoid hormones [37], prokineticin 2 (PK2) [38], and cardiotrophin-like cytokine (CLC) [39]. Additionally, the feeding/fasting schedule is an important external cue that contributes to the adjustment of the peripheral circadian clocks located in different organs [28,40].

At the molecular level, the circadian clock is driven by several transcription factors governing the core feedback loop including the transcriptional activators circadian locomotor output cycles kaput (CLOCK) [41,42] and brain and muscle ARNT-like protein 1 (BMAL1) as well as the transcriptional repressors PER1, PER2, and PER3 and CRY1 and CRY2 [43]. Structurally BMAL1 and CLOCK share one basic helix-loop-helix (BHLH) and two Per-Arnt-Sim (PAS) regions. These domains are necessary for heterodimerization and DNA binding. BMAL1 and CLOCK form a dimeric transcription factor that binds to E-box (5'-CACGTG-3') and E-box-like promoter elements to activate transcription of the Per and Cry genes, as well as Rev-Erbs (Rev-Erb $\alpha$ and $\beta$ ), retinoic acid-related orphan receptors (Rors: $\operatorname{Ror} \alpha, \beta$, and $\gamma$ ) and other clock-controlled genes (Figure 1). In turn, PERs and CRYs heterodimerize, translocate to the cell nucleus and inhibit the CLOCK:BMAL1 complex [2]. The second feedback loop is comprised of REV-ERBs [44] and RORs [45], which bind to the ROR response element (RORE) in the Bmal1 and Cry1 promoter to rhythmically activate (REV-ERBs) or repress (RORs) transcription [46]. The alternating occupancy of RORE by RORs or REV-ERB $\alpha$ occurs as a result of the robust rhythmic fluctuations of REV-ERB $\alpha$ levels following enhanced transcription of the Rev-erb $\alpha$ gene by CLOCK:BMAL1 $[44,45,47]$. To achieve a nearly 24 h cycle of the clock machinery, changes in the concentration of clock proteins and subcellular localization, post-transcriptional microRNA regulation, post-translational modifications including phosphorylation, acetylation, SUMOylation, methylation, and ubiquitination are crucial [48-51]. Circadian phosphorylation mediated by several kinases (GSK3 $\beta$, AMPK, PKA, CAMK-1, CKI $\alpha, \mathrm{CKI} \delta$, and CKI $\varepsilon$ ), phosphatases (PP1, PP2A, PP4, and PP5) regulates localization and stability of integral core clock proteins [52].

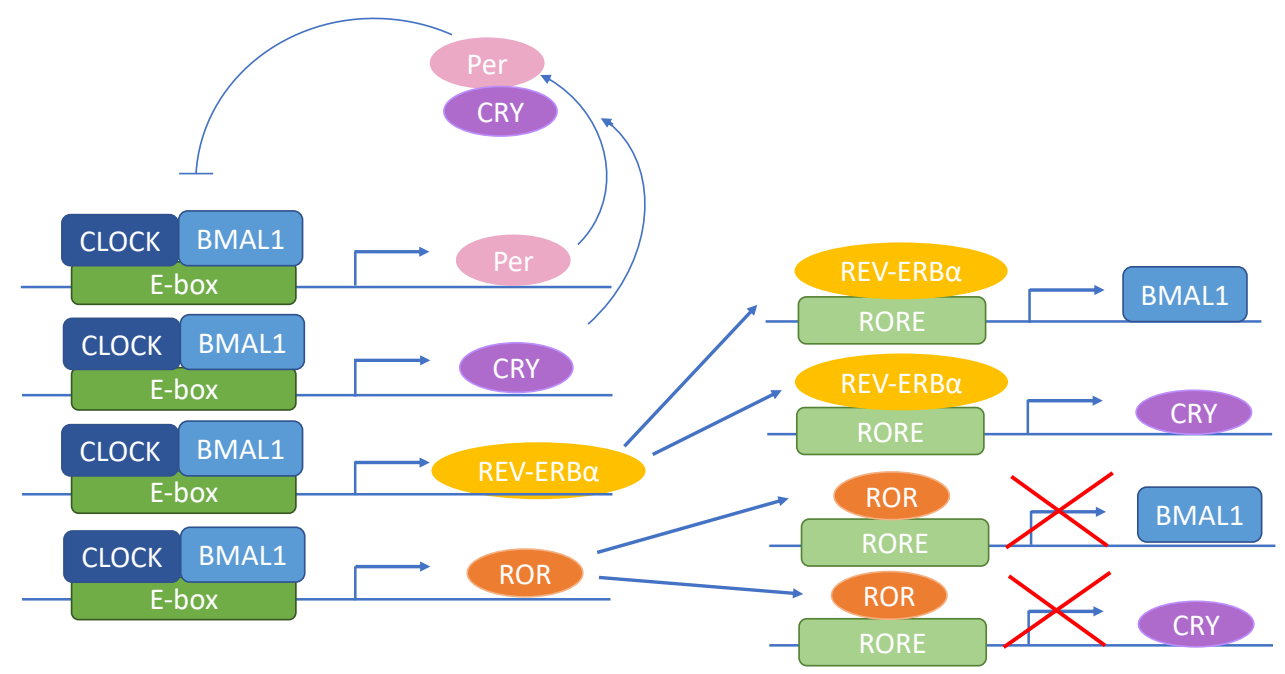

Figure 1. Transcription feedback loops driving circadian rhythm. CLOCK and BMAL1 heterodimers initiate expression of PERs, CRYs, REV-ERB $\alpha$, and RORs by binding to the E-box element. PER and CRY heterodimers inactivate CLOCK and BMAL1. REV-ERB $\alpha$ and RORs activate or inhibit, respectively, the expression of ROR response element (RORE) containing genes including Cry and Bmal1. Abbreviations: BMAL1-brain and muscle ARNT-like protein 1; CLOCK—circadian locomotor output cycles kaput; CRY_cryptochrome; PER_period, ROR—retinoic acid-related orphan receptor. 


\section{Caloric Restriction}

$\mathrm{CR}$ is a dietary approach involving a simple reduction of total energy intake and resulting in a myriad of beneficial responses ranging from the molecular cellular level to the whole-body system. $\mathrm{CR}$ increases mean and maximum life span in several species, including various strains of rats and mice, yeasts, worms, fruit flies, fishes, hamsters, owls, dogs, and cows [53-57]. In rodents, lifelong CR may extend lifespans by up to $50 \%$, with weaker effects when CR is initiated later in life [58]. CR both delays the onset and slows-down the progression of several diseases, including age-related type 2 diabetes, sarcopenia, cancer, atrophy of the brain grey matter, and autoimmune, neurodegenerative, and cardiovascular diseases [53-57]. The metabolic adaptation to CR and the foundation of its beneficial effects originate from a synchronized response of a complex network of pathways, the most essential of them being under the control of insulin/insulin-like growth factor 1 (IGF-1), sirtuins (SIRTs), adenosine monophosphate (AMP) activated protein kinase (AMPK), and target of rapamycin (TOR). Additionally, multiple factors (among them thyroid hormones, adipokines, and ghrelin) and bodily systems (including sympathetic and neuroendocrine systems) also contribute to the beneficial outcomes of CR [53]. As a consequence of the multi-level coordinated response, CR impacts the whole body in terms of diminished inflammation, resting metabolic rate, body temperature, fat content, and enhanced insulin sensitivity [59].

\section{The Impact of CR on Circadian Rhythm}

Multiple studies investigated the crosstalk between $C R$ and circadian rhythm. At the gene expression level, two clock genes, Per1 and Per2, are upregulated by CR in several tissues [60]. Comparison of gene expression in seven different tissues of mice submitted to CR highlighted circadian rhythms with Per2 being consistently upregulated in all of the tested tissues [61]. Besides Per1 and Per2, CR increases the daily average expression of hepatic Cry2 and Bmal1 but reduces the protein level of Clock at every time points tested thorough the day [23]. The effect of CR on the expression of some of the core circadian genes is affected in the liver of Bmal1 $\mathrm{KO}$ mice, which are considered as genetically arrhythmic. However, the induction of Cry1 expression by CR is preserved in these Bmal1 $\mathrm{KO}$ mice, suggesting the occurrence of both BMAL1-dependent as well as-independent regulatory mechanisms [23]. Of note, some aspects of circadian rhythms in behavior and physiology are sexually dimorphic [62,63]. The expression of the Rev-Erb $\alpha$, Ror, Cry1, and Cry2 genes along with several genes regulated by $\mathrm{CR}$ including flavin-containing monooxygenase 3 (Fmo3), major urinary protein 4 (Mup4), serpin family A member 12 (Serpina12), and cytochrome P450 4A12 (Cyp4a12) differs between males and females, whereas the liver expression of some circadian clock genes such as Bmal1, Per1, Per2, and Per3 as well as the effect of CR on their expression are gender-independent [64].

Importantly, classical CR in a laboratory set up, when mice are given one portion of chow daily, resembles TRF in animal models, as hungry, restricted animals tend to consume all or most of their food portion within a short period of time after the delivery. Both, CR, and TRF can entrain the peripheral circadian clocks leading to the synchrony of metabolism and physiology. However, as opposed to TRF, $\mathrm{CR}$ entrains the clock in the SCN [65-67]. Moreover, $\mathrm{CR}$-induced changes in hepatic gene expression are different from those of TRF, suggesting that $\mathrm{CR}$ exerts its effects by other means than periodic feeding [23].

The impact of $\mathrm{CR}$ on circadian rhythm has been evinced on multiple levels. In addition to peripheral effects, CR also resets the expression of several circadian clock genes in the SCN [68]. In addition, at the molecular level, most polysome-associated mRNA transcripts that are rhythmic in ad libitum fed mice lose their rhythms, and many new transcripts gain rhythms under CR. Only a small share of genes, including the circadian clock transcripts, preserve oscillations under CR as well as ad libitum feeding [69]. Besides gene expression, also global protein acetylation is highly circadian. Importantly, the acetylation rhythm is dampened in aged mice and can be rescued by CR [70]. Thus, CR regulates circadian clock gene expression in different tissues and affects both central and peripheral clocks at the transcriptional, translational, and posttranslational levels. 
During CR, the organism adapts to the limited available resources and synchronizes its metabolic activities to produce metabolic enzymes efficiently to maintain homeostasis, relying on phases of energy supply. CR likely recruits the circadian clock for this metabolic optimization. Changes in nutritional availability of metabolic cues are implicated in lifespan extension and attenuation of the aging-related phenotype in a clock-dependent manner [22,71,72]. Due to the here mentioned multiple interlinks between CR and the circadian clock, implicating a large number of metabolic pathways under the control of the circadian clock, some of the beneficial outcomes of CR likely take place via clock regulation. The crosstalk between the circadian clock pathways participating in CR mechanisms, such as the sirtuin, insulin/IGF, and mammalian target of rapamycin (m)TOR signaling pathways will be described in the following chapters. Importantly, as recently reviewed [73], PPARs are implicated in every aspect of molecular signaling and outcomes of CR.

\section{Molecular Pathways Affected by CR and Their Implication in the Circadian Rhythm}

\subsection{Insulin Signaling in Metabolism and Circadian Rhythm Regulation}

Insulin/IGF-1 pathway activity plays a major role in the control of aging [74-78] and in the beneficial effects of CR $[79,80]$. Insulin is a key regulator of glucose uptake and utilization in insulin-responsive tissues. Following food intake, increased blood glucose levels trigger pancreatic $\beta$-cells to secrete insulin. Free circulating insulin activates insulin receptors on the surface of target cells eliciting a signaling cascade initiated by the activation of insulin receptor substrates (IRS 1-4) followed by phosphorylation of phosphoinositide 3-kinase (PI3K), which manages metabolic response including PDK1 and Akt stimulation by phosphorylation. Akt signaling prompts glucose transporter 4 (GLUT4) to translocate to the cell membrane where it initiates cellular glucose uptake. Akt also stimulates the production of glycogen and inhibits gluconeogenesis. Moreover, Akt activates mTOR, which facilitates anabolic processes, while mTORC2 feeds back to regulate Akt [81]. Insulin signaling affects multiple downstream pathways including mitogen-activated protein kinase (MAPK), which controls growth, sterol regulatory element-binding protein 1 (SREBP-1), which stimulates the synthesis of lipid and cholesterol as well as the family of Forkhead (FOXO) transcription factors regulating metabolism and autophagy [82,83]. Inhibition of IGF-1/PI3K/Akt signaling contributes to the anti-cancer and DNA-repair activity of CR [84-86].

The direct interconnection between $\mathrm{CR}$ and circadian rhythms has been evinced by the fact that Igf-1 expression is regulated by both CR and the circadian clock [64]. Interestingly, Igf-1 expression is rhythmic and shows sexual dimorphism [64]. Furthermore, a genome-wide RNAi screen for genes that regulate cellular clock functions in human cells identified the insulin signaling pathway as the most overrepresented pathway [87]. Accordingly, the impact of CR on plasma IGF-1 and insulin level is compromised in mice deficient for Bmal1 [71]. Further, the postprandial release of insulin resets peripheral clocks by regulating the expression of core circadian genes. Insulin rapidly increases the expression of Per 2 in insulin-sensitive tissues like the liver, muscle, or adipose tissue, but not the lung or brain [88]. Insulin secreted upon refeeding-after-fasting stimulates Per2 and reduces Rev-erba expression in hepatocytes [27]. The capacity of insulin to initiate entrainment of the liver clock was demonstrated by the administration of insulin in cultured rat hepatocytes which acutely induced expression of Per1, Per2, and Dec1 [88]. Accordingly, inhibition of pathways downstream of insulin signaling, such as MAPK and PI3K, blocks the induction of the Per1 and Per2 clock genes [88].

Next to insulin, glucose is a circadian clock regulator. Glucose levels control AMPK activity, which phosphorylates and controls the stability of the CRY proteins [89]. In rats, glucose infusion during the light phase strongly induces expression of Per2 in the SCN and reduces Per2 expression in the liver [90]. Accordingly, a reduced level of glucose availability delays the light-induced phase shift [91]. Glucose also reduces the expression of Per1 and Per2 in fibroblasts in vitro [92].

Reciprocally, the circadian clock in the pancreas regulates insulin and glucagon production and secretion and their signaling in SCN via the autonomic nervous system [93-96]. Glucagon secretion 
is also regulated by $\operatorname{Rev-Erb} \alpha$ [94]. In vitro islet $\beta$-cells exhibit robust rhythms of both Bmal1 and Per1 [95,97], while disruption of circadian clock functions in pancreas-specific Bmal1 KO mice leads to glucose intolerance, defective insulin production and secretion [95]. BMAL1 and CLOCK contribute to the regulation of the recovery from the hypoglycemic response to insulin [98]. Mice deficient in BMAL1 and CLOCK exhibit dysregulated glucose homeostasis, impaired glucose tolerance, and reduced insulin sensitivity [93]. On the contrary, $\mathrm{KO}$ of the negative arm of the circadian machinery, that is invalidation of Crys, Pers, or Rev-erb $\alpha$ leads to increased insulin levels [99-101]. In the Per2 KO mouse, insulin secretion is more effectively stimulated by glucose and its analogs compared to WT animals. At the same time, the circadian rhythm of hepatic insulin-degrading enzyme (Ide) is disrupted leading to decreased insulin clearance. Consequently, Per2 KO animals suffer from hyperglycemia [100].

Control of glucose homeostasis requires both the central and peripheral clocks, and disruption of synchronization between them affects glucose metabolism negatively [102]. CLOCK drives the transcriptional stimulation of glycogen synthase 2 (Gys-2) and therefore modulates the circadian rhythms of hepatic glycogen synthesis [103]. BMAL1 and CLOCK stimulate gluconeogenesis that consequently is reduced in the $\mathrm{KO}$ models of these proteins [98]. Similarly, ROR $\alpha$ directly induces phosphoenolpyruvate-carboxykinase (Pepck) expression [104] and thus, $\operatorname{ROR} \alpha$ deficiency, as well as treatment with $\operatorname{ROR} \alpha$ antagonists, inhibits PEPCK expression and glucose production [105]. Accordingly, glucose-6-phosphatase (G6Pase) and PEPCK are suppressed in HepG2 cells overexpressing Rev-erb $\alpha$, encoding the physiological repressor of ROR $\alpha$. Accordingly, silencing Rev-erb $\alpha$ significantly increases the expression of G6Pase and PEPCK $[104,106,107]$. Alike, during fasting, rhythmically expressed CRY proteins in the liver reduce gluconeogenesis through phosphorylation of cAMP response element-binding protein (CREB) [108], and phosphoenolpyruvate carboxykinase 1 (PCK1) by direct interaction of CRY with the Pck1 promoter [109]. Furthermore, during feeding and acute fasting, PER2 dampers gluconeogenesis and enhances glycogen storage by decreasing the activity of glycogen phosphorylase (GP) [110].

\section{2. mTOR Signaling and the Circadian Rhythm}

The mTOR pathway is a key effector pathway of CR and it is known for monitoring the availability of nutrients and regulating longevity. TOR is one of the Ser/Thr protein kinases from the family of phosphatidylinositol 3 (PI3) kinase-related kinases [111,112] and it functions as a key component of two complexes, mTORC1 and mTORC2 [111]. mTORC1 is sensitive to cellular energy levels, nutrient status, mitogenic signals, and oxygen levels and it is inhibited by rapamycin. mTORC1 signaling leads to the regulation of mRNA translation and autophagy. mTORC2 is not rapamycin sensitive and operates as a regulator of the cellular actin cytoskeleton $[113,114]$. The mTOR pathway integrates intracellular and extracellular physiological stimuli. In this pathway, the protein complex of tuberous sclerosis proteins 1 and 2 (TSC1 and TSC2) mediates upstream signals from growth factors, such as insulin and IGF-1 to mTORC1. Activation of mTOR mediates the phosphorylation of several executor proteins involved in mRNA translation and ribosome biogenesis, such as ribosomal S6 kinase 1 (S6K1) and eukaryotic initiation factor 4E-binding protein (4E-BP) [115-117]. mTORC1 downstream signaling controls autophagy and metabolism, including the glycolytic turnover and anabolic processes associated with the fed state including lipogenesis [118-121], cholesterol synthesis via activation of SREBP-1/2 [118,122,123], and protein synthesis [124,125].

mTOR activity in vivo is induced by the abundance of nutrients and gradually decreases during fasting. However, food-independent rhythmicity in activity and expression of the mTORC1 complex members has been observed in the SCN and liver, cardiac and skeletal muscles, adipocytes, and retinal photoreceptors but not in the intestine or lung [126-134]. In the mouse brain, mTORC1 activities exhibit daily alterations in the arcuate nucleus, hippocampus, and the frontal cortex $[130,135,136]$, all regions that manage circadian rhythms, feeding, learning, memory, and emotions. The oscillations of mTOR activity are delimited by internal and external regulators [137]. In the brain of Drosophila, TOR rhythms are found particularly in the ventral lateral neurons [138,139]. Neuronal TORC1 and AKT 
signaling have been shown to drive behavior [138]. Also, in the SCN, mTORC1 signaling is activated by light and controls behavior in a circadian manner [126,127,140]. Brief light exposure of mice during the night, but not during the day, triggers instant phosphorylation of the mTOR translation effectors S6K1, S6 ribosomal protein (S6), and translational repressor 4E-BP1 [126]. A KO of 4E-BP1 in mice leads to a higher amplitude of molecular rhythms in the SCN, increased capacity for re-entrainment to a shifted light/dark cycle, and higher resistance to the disruption of rhythm by constant light [140]. In vivo, infusion of the inhibitor of mTOR1 rapamycin leads to an attenuation of the phase-delaying effect of early-night light. Equally, disruption of mTOR during the late-night augments the phase-advancing effect of light. At both the early- and late-night time points, abrogation of mTOR signaling leads to a significant attenuation of light-induced PER protein expression [141]. Conversely, constitutive activation of mTOR in Tsc2-deficient fibroblasts alters the dynamics of clock gene rhythmicity and raises levels of principal clock proteins, including CRY1, BMAL1, and CLOCK [142]. Heterozygous $m$ Tor KO mice present a lengthened circadian period of locomotor activity rhythms both in constant darkness and constant light [142]. mTOR inhibition lengthens the period and dampens the amplitude of circadian clock proteins, whereas mTOR activation shortens the period and augments amplitude in hepatocytes, adipocytes, and human U2OS cells $[142,143]$. In Drosophila, TOR modulates the circadian period in opposite direction compared to mice. Overexpressing S6K in the ventral lateral neurons, the central pacemaker cells, extends the circadian period [138]. Consistently, KO of Tor in Per expressing cells shortens the period of locomotor rhythms in Drosophila [139].

Importantly, the intracellular concentration of $\mathrm{Mg}^{2+}$ ions act as a cell-autonomous timekeeping component that controls key clock properties from unicellular algae to human. Furthermore, $\mathrm{Mg}^{2+}$ ions oscillations regulate circadian control of translation by mTOR [143].

In the liver, fasting/feeding cycles regulate the energy sensor AMPK and mTORC1 $[28,129,130]$ independently of CRY1 and CRY2 but partly relying on BMAL1 [137]. S6K1 rhythmically phosphorylates BMAL1 at an evolutionarily conserved site to activate it for modulation of mRNA translation and protein synthesis. Therefore, protein synthesis rates show circadian oscillations that are dependent on BMAL1 [131], which deficiency increases mTORC1 activity both in vivo and in vitro [130]. Increased mTOR signaling correlates with faster aging while treatment with rapamycin extends the lifespan of prematurely-aging Bmal1 KO mice by 50\% [130]. Therefore, increased BMAL1 activity likely contributes to lower mTORC1 activity in CR. In summary, the regulation of mTOR downstream and upstream of the circadian rhythm connects daily oscillations with sensing of the nutrient status (Figure 2).

\subsection{AMPK as an Energy Sensor and Executor of Circadian Metabolic Activities}

AMPK serves as a key energy sensor of the AMP:ATP and ADP:ATP ratios. AMPK, activated at low levels of ATP, suppresses energy-consuming anabolic pathways and promotes catabolism resulting in the recruitment of stored energy to reestablish the ATP levels [144]. AMPK impacts metabolism via several downstream effectors including CREB-regulated transcriptional coactivator-2 (CRTC2) [145], TBC1D1/AS160 [146,147], peroxisome proliferator-activated receptor $\gamma$ coactivator $1 \propto$ (PGC-1 $\alpha$ ) [148], and histone deacetylase 5 (HDAC5) [149]. Functionally, AMPK inhibits fatty acid (FA), TG and cholesterol synthesis, while stimulating FA uptake and $\beta$-oxidation [150-154]. Furthermore, AMPK reduces protein synthesis by inhibiting mTOR [155]. AMPK also affects the metabolism of glucose by stimulating glycolysis [156] and inhibiting glycogen synthesis [157] and gluconeogenesis [158-160]. It also drives nutrient-induced insulin secretion from islet $\beta$-cells [161] and glucose uptake by GLUT4 [162]. Besides metabolism, AMPK plays a role in inflammation, cell growth, autophagy, and apoptosis [163].

The circadian clock is paired with cellular metabolic fluctuations via nutrient-sensing pathways. While the expression of six of the transcripts encoding subunits of mammalian AMPK does not vary during the day, that of the $A M P K \beta 2$ subunit is eight times higher in the middle of the day than it is at night. AMPK $\beta 2$ determines the cellular localization of the heterotrimeric AMPK 
complex [164]; therefore, the presence of the AMPK $\alpha 1$ subunit in the nucleus increases at the time of day when AMPK $\beta 2$ expression peaks [89]. The rhythmic hepatic activity and nuclear localization of AMPK correlate inversely with CRY1 levels, which is likely due to the fact that stimulation of AMPK leads to phosphorylation and degradation of CRY [89]. Further, activation of AMPK by 5-aminoimidazole-4-carboxamide ribonucleoside (AICAR) or metformin in mouse livers causes a phase shift of the clock, and animals in which the AMPK pathway is genetically disrupted show alterations in peripheral clocks $[89,165]$. Moreover, acute AICAR stimulation alters the expression of clock genes in WT mice but not in mice lacking the AMPK $\gamma 3$ regulatory subunit [166]. Genetic disruption of either AMPK $\alpha 1$ or AMPK $\alpha 2$ subunit dampens the rhythm of body temperature, the free-running activity, changes the circadian pattern of core clock gene expression in mice in an isoform- and tissue-specific manners [165]. In mouse muscles, AMPK regulates the expression patterns of the circadian genes Cry2, Rev-erb $\alpha$, and Bhlhb2 (basic helix-loop-helix domain containing class B 2) [166]. Moreover, AMPK is capable of phosphorylating casein kinase $\varepsilon(\mathrm{CKI} \varepsilon)$ and thereby increases its enzymatic activity, indirectly leading to a destabilization of PER2 [167]. PGC- $-1 \alpha$, which co-activates the RORs and consequently stimulates the expression of Bmal1 and Rev-erb $\alpha$, is phosphorylated by AMPK $[148,168,169]$. PGC $-1 \alpha$ is required for cell-autonomous clock function [169] and PGC $-1 \alpha$ KO mice show an abnormal diurnal rhythm of physical activity, body temperature, and metabolic rate, due to disrupted expression of clock genes and genes involved in energy metabolism. Besides the direct impact on ATP levels, AMPK affects the energy status by promoting feeding through signaling in the hypothalamus as well as by adjusting circadian metabolism $[170,171]$. AMPK may thereby mediate the influence of fasting/feeding cycles on the circadian clock (Figure 2).

\subsection{SIRT Energy Sensors in the Context of CR and Daily Rhythmicity}

SIRTs serve as energy sensors by detecting the ratio of reduced to oxidized nicotinamide adenine dinucleotide $\mathrm{NAD}^{+}: \mathrm{NADH}$ and react as transcriptional effectors mostly through their HDAC activity. SIRTs are class III HDACs that manage processes connected with nucleic acid biology including DNA repair, homologous recombination, and histone deacetylation, as well as transcriptional gene silencing [172,173]. There are seven subtypes of SIRTs (SIRT1-7) in mice and humans which differ in their cellular localization and function. SIRT1-SIRT3, SIRT5, SIRT6, and SIRT7 act as deacetylases, while SIRT4 and SIRT6 have ADP-ribosylation activity. Besides histones, SIRTs modify also several transcriptional regulators including the nuclear factor kappa-light-chain enhancer of activated B cells (NF-kB), p53, FOXO, PGC $-1 \alpha$, as well as enzymes, including acetyl coenzyme A (CoA) synthetase 2 (AceCS2), long-chain acyl-coenzyme A dehydrogenase (LCAD), 3-hydroxy-3-methylglutaryl-CoA synthase 2 (HMGCS2), superoxide dismutase 2 (SOD-2), and structural proteins, such as $\alpha$-tubulin [174-178]. Therefore, SIRTs impacts multiple processes and pathways including circadian clocks, cell cycle, mitochondrial biogenesis, and energy homeostasis, consequently influencing aging, apoptosis, inflammation, and stress resistance [179,180]. SIRT1 is mostly associated with metabolism. In S. cerevisiae an extra copy of the Sir2 gene, a yeast homolog of mammalian Sirt1, increases lifespan [181,182], whereas the deletion of Sir2 shortens it [181]. In yeast and Drosophila, lack of the Sirt1 homolog offsets CR-triggered life extension [183-185]. A yeast analog of Sirt1 takes part in DNA repair and regulates aging-related gene expression [186].

PGC $-1 \alpha$, one of the main metabolic effectors of SIRT1, is activated by SIRT1-mediated deacetylation [187,188]. Activated PGC-1 $\alpha$ enhances hepatic gluconeogenesis [187], mitochondrial activity in muscle and BAT leading to increased exercise capacity and thermogenesis; consequently, PGC-1 $\alpha$ promotes protection against obesity and metabolic dysfunction [189]. SIRTs interact also with factors involved in response to CR including the FOXO family of transcription factors [190-192], which affects gluconeogenesis and glucose release from hepatocytes [193], cell differentiation, metabolism as well as longevity regulation [194-196]. Further, AMPK enhances SIRT1 activity by increasing cellular NAD ${ }^{+}$levels $[197,198]$ and activation of SIRT1 may cause AMPK 
phosphorylation via deacetylation-dependent activation of the AMPK-activating kinase liver kinase B1 (LKB1) [199,200].

SIRT1 controls the circadian expression of the core clock genes Bmal1, Ror $\gamma$, Per2, and Cry1. Also, SIRT1 is recruited by CLOCK:BMAL1 chromatin at circadian promoters [201]. Further, the levels of $\mathrm{NAD}^{+}, \mathrm{NADP}^{+}, \mathrm{NADH}$, and NADPH affect the binding capacity of CLOCK-BMAL1 heterodimers to E-box elements [202]. Similarly, resveratrol, a polyphenolic SIRT activator, regulates the expression of clock genes Per1, Per2, and Bmal1 in Rat-1 fibroblast cells [203]. It also modifies the rhythmic expression of clock genes (Clock, Bmal1, and Per2) and lipid metabolism-related genes controlled by the clock (Ppar $\alpha$, Srebp-1c, Acc1, and Fas) in HFD-fed mice [204] and reverses the change induced by high-fat feeding in the expression of Rev-Erb $\alpha$ in adipose tissue of rats [205]. SIRT1 also promotes the deacetylation and subsequent degradation of PER2 in a circadian manner [201].

The rhythmic acetylation of BMAL1 and acetyl-histone H3 Lys9/Lys14 at circadian promoters correlates with SIRT1 HDAC activity that is regulated in a circadian manner. Therefore, genetic or pharmacological inhibition of SIRT1 activity causes disturbances in the acetylation of H3 and BMAL1 and the circadian rhythm [206]. Moreover, the circadian transcription factor CLOCK has histone acetyltransferase (HAT) activity, and SIRT1 HDAC activity counteracts the HAT activity of CLOCK $[201,206]$. Another circadian protein, REV-ERB $\alpha$ regulates pancreatic glucagon secretion via the AMPK/nicotinamide phosphoribosyltransferase (NAMPT)/SIRT1 pathway [94]. Further, the expression of NAMPT, a rate-limiting enzyme involved in $\mathrm{NAD}^{+}$production through the salvage pathway, is regulated by the BMAL/CLOCK heterodimer. Consequently, $\mathrm{NAD}^{+}$levels exhibit rhythmic daily oscillations $[207,208]$. Moreover, by being recruited to the Nampt promoter, SIRT1 contributes to the circadian synthesis of its own coenzyme [208]. Inhibition of NAMPT promotes fluctuations of Per2 by releasing CLOCK:BMAL1 from suppression by SIRT1. In turn, CLOCK binds to the Nampt promoter and stimulates its activity, thereby contributing to a feedback loop comprising NAMPT/NAD ${ }^{+}$and SIRT1/CLOCK:BMAL1 [207].

SIRT3 also interacts with the circadian rhythm. It sets the pace in the acetylation and activity of oxidative enzymes and consequently respiration in isolated mitochondria. Bmal1 KO mice have significantly decreased SIRT3 activity, which affects mitochondrial oxidative function, and supplementation with nicotinamide mononucleotide $(\mathrm{NMN})$, a $\mathrm{NAD}^{+}$precursor, restores SIRT3 function and enhances oxygen consumption in these animals [209]. Importantly, the rhythm of cyclic global protein acetylation dampens with aging in mice [70]. CR regulates SIRT1 activity and therefore it modulates the circadian acetylation of AceCS1, a pathway controlling rhythmic nucleocytoplasmic acetyl-CoA production [210,211]. Consequently, CR rescues the hepatic protein acetylation rhythm over the day/night cycle in mice. Accordingly, the circadian transcriptome of CR-mediated effects on circadian reprogramming and SIRT1-specific transcriptome overlaps [70] indicating a pivotal role of SIRT1 in connecting CR and the circadian rhythm (Figure 2). 


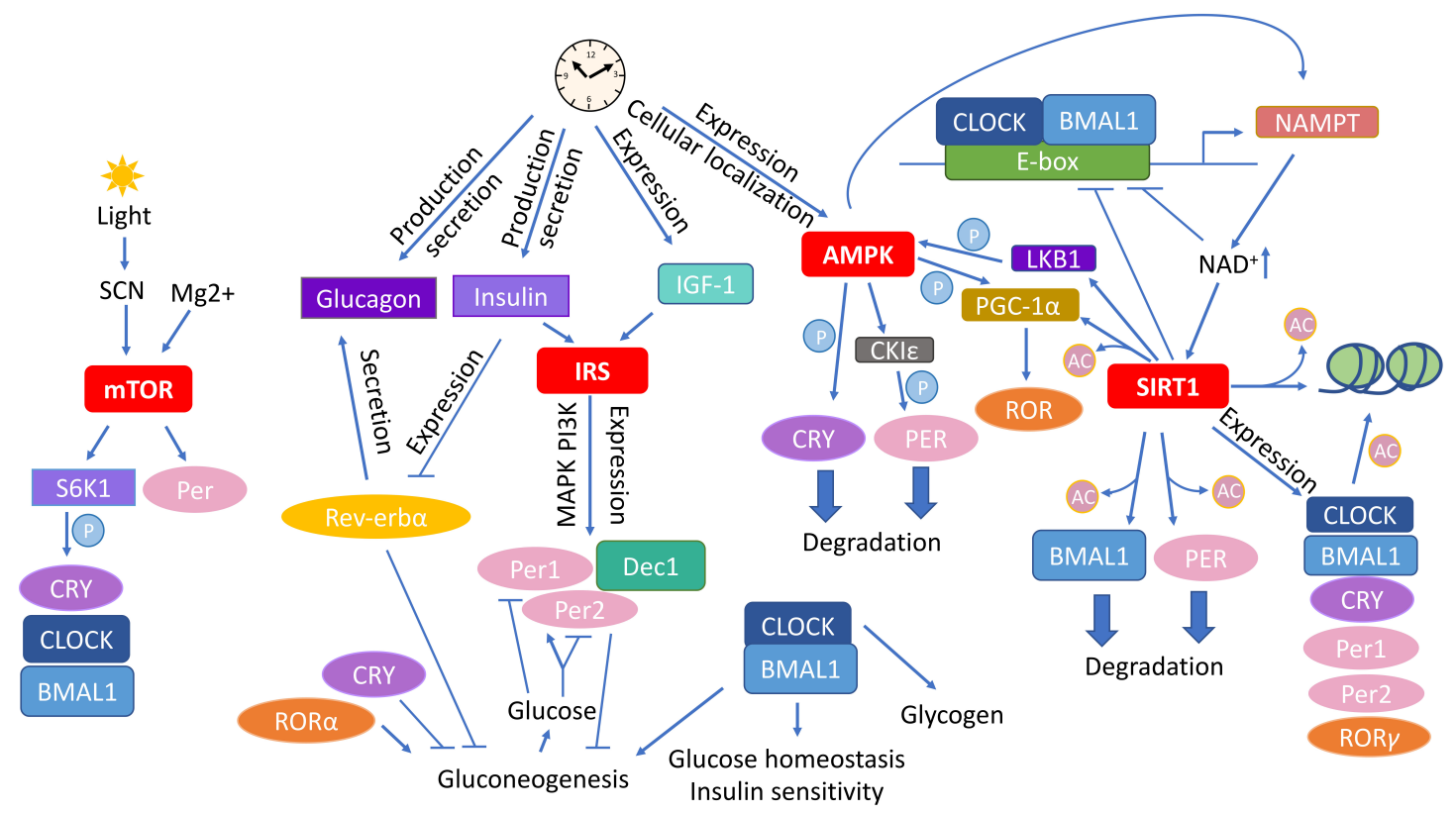

Figure 2. Circadian rhythm affects the main molecular pathways mediating the outcome of caloric restriction (CR). Various types of interactions connect the CR-associated pathways mTOR, insulin signaling, AMPK, and sirtuins with circadian rhythm. Abbreviations: AMPK-adenosine monophosphate (AMP) activated protein kinase; $\mathrm{CKI} \varepsilon$-casein kinase $\varepsilon$; CLOCK—circadian locomotor output cycles kaput; Dec1—differentially expressed In chondrocytes 1 ; IGF-1-insulin-like growth factor 1; IRS-insulin receptor substrates; LKB1-liver kinase B1; mTOR-mammalian target of rapamycin; NAD—nicotinamide adenine dinucleotide; NAMPT—nicotinamide phosphoribosyltransferase; SIRT1—Sirtuin 1; SCN—suprachiasmatic nucleus, S6K1 - ribosomal protein S6 kinase 1. The circled Ac indicates acetylation and circled P phosphorylation.

\section{PPARs}

The ligand-dependent receptors PPARs form a nuclear receptor subfamily which comprises three isotypes, PPAR $\alpha$ (NR1C1), PPAR $\beta / \delta$ (NR1C2), and PPAR $\gamma$ (NR1C3) [212-214]. PPARs play roles in multiple processes including FA and eicosanoid signaling, cell proliferation and differentiation, tissue repair and remodeling, bone formation, insulin sensitivity, glucose and lipid metabolism. Synthetic ligands [thiazolidinediones (TZD) and fibrates] of PPARs are commonly used in the therapy of glucose, and lipid disorders as well as in the prevention and treatment of cardiovascular and metabolic diseases [215-217]. Diverse FAs, phospholipids, prostacyclins, prostaglandins, and leukotrienes serve as natural ligands of PPARs [218,219] and also are involved in other biological processes, which indicate a potential link between PPARs and nutrition, metabolism, and inflammation. In response to CR, PPAR expression patterns vary vastly in different tissues and organs. In brief, the expression of PPAR $\alpha,-\beta / \delta$, and $-\gamma$ in the heart, PPAR $\alpha$ in white adipose tissue (WAT), and PPAR $\gamma$ in the liver remains unchanged during CR. On the contrary, the expression of PPAR $\beta / \delta$ in the liver, PPAR $\alpha$ in the spleen, and PPAR $\alpha$, $-\beta / \delta$, and $-\gamma$ in muscle is decreased, whereas that of PPAR $\alpha$ in the liver and intestinal epithelium is increased [220-228]. In rat kidneys, 60\% CR prevents age-related reduction in PPAR activity [229].

PPARs contribute to CR-related outcomes by regulating many pathways, all of which we have reviewed recently [73], such as mTOR, insulin signaling, AMPK, SIRT, inflammation, oxidative stress, mitochondrial function, energy metabolism, aging, hunger, and microbiota composition. Simultaneously, PPARs act as molecular connectors joining clock genes and specific rhythmic metabolic outputs. All PPARs exert their functions in a circadian manner and their expression is regulated by both core clock genes and clock-controlled genes. Moreover, PPARs and the core clock genes cross-regulate each other at the transcription level. Additionally, CLOCK/BMAL1 and PPARs 
synergistically regulate gene expression as CLOCK/BMAL1 heterodimers increase the transcriptional activity of some PPAR target genes. Upon PPAR response element (PPRE) removal from the promoter of these genes, CLOCK/BMAL1 loses its transcriptional effects [230]. Finally, it is important to bear in mind that there are multiple interactions between each PPAR isotype and the circadian rhythm (Figure 3).

\subsection{PPAR $\alpha$}

Most studies on the implication of PPARs in CR and circadian rhythm are about PPAR $\alpha$, which is particularly important for lipid metabolism and is expressed at relatively high levels in organs with significant FA catabolism, such as the liver and brown adipose tissue (BAT) [231]. PPAR $\alpha$ synchronizes metabolism by regulating genes associated with FA transport, peroxisomal and mitochondrial $\beta$-oxidation, ketogenesis, and gluconeogenesis [218]. Considering the adaptational role of PPAR $\alpha$, its ligands can be seen as mimetics of CR [232]. As a sensor of the energy status, $\operatorname{PPAR} \alpha$ adjusts metabolic processes to both, scarcity and abundance of nutrition.

During fasting, upon depletion of dietary glucose, PPAR $\alpha$ enhances glucose import, glycolysis, and glycogenolysis [233-236]. It also increases FA oxidation and glucose-induced insulin secretion in $\beta$-cells [237,238], thereby improving glucose management [239], and insulin sensitivity [240-244]. Not surprisingly, PPAR $\alpha \mathrm{KO}$ mice show reduced expression of some of the genes involved in gluconeogenesis and glycogen metabolism [245] and they develop age-dependent hyperglycemia [246]. Following $24 \mathrm{~h}$ fasting, the PPAR $\alpha$ KO mice display severe hypoglycemia together with elevated plasma insulin concentrations $[247,248]$.

Fasting results in carbohydrate depletion, fat mobilization, and ketone body production, all of which rely on PPARs. In response to glucose shortage, PPAR $\alpha$ supports FA uptake, $\beta$-oxidation, FA catabolism, lipogenesis, and ketone body production [248-250] by regulating the expression of most of the rate-limiting enzymes of ketogenesis, such as HMG-CoA synthase and of $\beta$-oxidation including ACOX1, enoyl-CoA hydratase, and 3-hydroxyacyl CoA dehydrogenase (EHHADH), carnitine palmitoyltransferases 1 and 2 (CPT1/2), medium, long and very long-chain acyl-CoA dehydrogenases (MCAD, LCAD, VLCAD), fibroblast growth factor 21 (FGF21). In the liver, 19\% of genes whose expression is changed by $\mathrm{CR}$ and are involved in lipid metabolism, inflammation, and cell growth depends on PPAR $\alpha$ and is not affected by CR in PPAR $\alpha$ KO mice [232]. Consequently, PPAR $\alpha$ KO mice show impaired fasting-induced hepatic responses, which causes hypoketogenesis and liver steatosis [248-250].

PPAR $\alpha$ modulates an important aspect of CR response, hunger perception. Endocannabinoid oleoylethanolamide (OEA), a ligand of PPAR $\alpha$ is particularly well recognized for appetite regulation [251]. OEA is synthesized in enterocytes in response to fat consumption and is increased by sympathetic activity and bile acids that activate $\mathrm{N}$-acylphosphatidylethanolamines hydrolyzing phospholipase D (NAPE-PLD) [252,253]. OEA has an anorectic effect via PPAR $\alpha$ activation and it reduces meal size or delays meal intake, which results in body weight loss [251,254-256]. OEA acts peripherally via afferent sensory fibers of the vagal nerve in the intestine. This signaling promotes the secretion of the neuropeptide oxytocin and satiety by increasing the expression of c-fos in the nucleus solitary tract of the brainstem and the paraventricular nucleus of the hypothalamus [257,258]. OEA synthesis is increased following gastric bypass surgery that requires intestinal PPAR $\alpha$ expression to reduce food intake [259]. Moreover, a single nucleotide polymorphism (SNP) in PPAR $\alpha$ is associated with an increased risk of high altitude appetite loss [260], and activation of hypothalamic PPAR $\alpha$ normalizes food intake in hypophagic Fas KO mice [261]. Unexpectedly, challenging hepatic Ppar $\alpha$ KO mice with carbohydrates revealed a PPAR $\alpha$-dependent glucose response for FGF21. This effect is associated with an increased preference of these mice for sucrose [262]. Finally, dietary protein restriction increases FGF21 expression in human and rodent plasma, an effect which depends on increased phosphorylation of eukaryotic initiation factor $2 \alpha$ (eIF2 $\alpha$ ) in the liver, eIF2 $\alpha$ kinase general control nonderepressible 2 (GCN2), and PPAR $\alpha$ signaling [263]. 


\subsubsection{PPAR $\alpha$ and Molecular Effectors of CR}

PPARs interact with all of the major pathways managing the response to CR. The diverse interactions between mTOR and PPARs impact FA synthesis, glucose metabolism, oncogenesis, and the immune system. mTORC1 adjusts ketone body production upon fasting [264] and mice with constitutive hepatic activation of mTORC1 present low PPAR $\alpha$ levels and are not able to induce ketogenesis in response to fasting [264]. In the fed state, the insulin-dependent PI3K pathway activates mTORC1, which inhibits PPAR $\alpha$ activity and ketogenesis [264]. Additionally, insulin-dependent phosphorylation and thus inhibition of cytoplasmic FA synthase (FAS), which is mediated by mTORC1, limits the synthesis of PPAR $\alpha$ ligands. Conversely, when mTOR is inhibited during fasting, FAS generates endogenous PPAR $\alpha$ ligands [265]. In the intestine, mTOR activity increases with age, which is accompanied by inhibition of PPAR $\alpha$. Consequently, levels of the primary Wnt feedback inhibitor, Notum increase, and Wnt signaling is reduced leading to the diminished regenerative capacity of stem cells in the Paneth cell niche [266]. Similarly, in the livers of old mice, elevated mTORC1 activity [264] coincides with diminished activity of PPAR $\alpha$ and reduced ketogenesis [267-269]. Unsurprisingly, mTORC1 inhibition prevents aging-induced loss of PPAR $\alpha$ activity and ketone body production [264]. Finally, CR induces autophagy in the liver and other organs by integrating, mTOR, and PPAR $\alpha$ functions $[270,271]$.

As already mentioned, AMPK and PPAR $\alpha$ both sense the energy status and adjust metabolism to nutritional changes. PPAR $\alpha$ stimulates the expression of proteins involved in restoring ATP levels and therefore regulates AMPK activity. Moreover, PPAR $\alpha$ and AMPK act to regulate long-term and short-term FA oxidation, respectively. Therefore, during fasting, as glucose levels drop and FA levels rise, AMPK and PPAR $\alpha$ coordinate their actions. High intracellular AMP levels induce AMPK, which stimulates mitochondrial FA uptake while PPAR $\alpha$ enhances the hepatic $\beta$-oxidation capacity $[218,265,272,273]$. The activation of PPAR $\alpha$ by AMPK occurs in several tissues including muscle, liver, and pancreas [274-280]. Agonist activation of PPAR $\alpha$ also activates AMPK showing that the stimulation of AMPK and PPAR $\alpha$ is reciprocal [281-283].

Similarly, there is a positive activation loop between PPAR $\alpha$ and SIRT1. SIRT1 deletion in hepatocytes decreases PPAR $\alpha$ activity and reduces FA $\beta$-oxidation, while SIRT1 overexpression stimulates PPAR $\alpha$ target genes. Further, activation of PGC $-1 \alpha$ by deacetylation, requires interaction between SIRT1 and PPAR $\alpha$ [284]. Moreover, PPAR $\alpha$ and SIRT1 mutually suppress the expression of genes regulating mitochondrial activities that are controlled by the estrogen-related receptors (ERRs) during fasting [285-287].

\subsubsection{PPAR $\alpha$ in Circadian Rhythm}

PPAR $\alpha$ is expressed according to a diurnal rhythm in mouse liver, heart, kidney, and, to a smaller extent, in the SCN $[288,289]$. It is directly linked with the circadian clocks as it maintains the circadian oscillation of the Bmal1 gene in the brain and muscle by binding to its promoter (Figure 3). Accordingly, fenofibrate, a PPAR $\alpha$ ligand, promotes circadian clock gene expression in cell culture, up-regulates hepatic Bmal1 in vivo, and Ppar $\alpha$ KO mice exhibit altered hepatic circadian expression of Bmal1 and Per3 [290]. Reversely, BMAL1 is an upstream regulator of Ppard expression [290]. Similarly, the CLOCK-BMAL1 heterodimer transactivates Ppar $\alpha$. CLOCK interacts with the E-box-rich region of the Ppar $\alpha$ promoter and, in homozygous Clock KO mice, the hepatic circadian expression of Ppar $\alpha$ is abolished [291]. Interestingly, Rev-erb $\alpha$ is also a PPAR $\alpha$ target gene [292].

Besides its transcription regulatory role, PPAR $\alpha$ also interacts directly with clock proteins. PER2 interacts with PPAR $\alpha$ and serves as its transcriptional coregulator. Consequently, PER2 is rhythmically bound at the promoters of PPAR target genes in vivo [293]. Considering multiple interactions between PPAR $\alpha$ and circadian clock proteins it is important to reflect on the impact of medical drugs, mostly lipid-lowering ones, acting as PPAR $\alpha$ ligands. Fenofibrate increases transcription and resets rhythmic expression of BMAL1, PER1, PER3, and REV-ERB $\alpha$ in mouse livers [290] and cultured hepatocytes [292]. Bezafibrate was shown to phase-advance the circadian 
expression of BMAL1, PER2, and REV-ERB $\alpha$ in the cortex, liver, and fat of mice but without affecting the SCN [294]. Additionally, bezafibrate advances the active phase of mice under light-dark conditions in a photoperiod-dependent manner; therefore, it is involved in the entrainment of the circadian clock to environmental light-dark conditions [294,295].

Lipid homeostasis is controlled by the circadian clock and disruption of rhythmicity results in dyslipidemia and obesity in various clock mutant mouse models. Rev-Erb $\alpha$ KO mice exhibit elevated VLDL triglyceride levels [296], in Bmal KO mice triglycerides oscillations are dampened in plasma [98], Clock KO mice show hyperlipidemia and hepatic steatosis [297] whereas Per2 $\mathrm{KO}$ mice have reduced whole-body fat, total triglycerides as well as FAs in plasma [298]. Accordingly, around $15 \%$ of total metabolites undergo diurnal regulation in human plasma with $75 \%$ of them being lipids [299]. Similarly, about $13 \%$ of lipid metabolites exhibit circadian changes in human plasma [300], with a high prevalence of diglycerides, and triglycerides peaking in the middle of the day. Consistently, the oscillation of triglycerides in the rat plasma corresponds to the feeding cycle [301]. In mouse liver, $17 \%$ of quantified lipids display circadian rhythmicity with all triacylglycerols (TAG) reaching their peak levels around CT8 which parallels PPAR $\alpha$ peak expression in the liver. Surprisingly, Per1/2 KO mice show variations of a similar fraction of lipids, however, with a different composition than in the WT mice. Moreover, PPAR $\alpha$ retains its circadian expression upon Per1/2 deletion [302]. In the same way, adipose tissue (BAT, iWAT, and eWAT) shows a cyclic expression of the circadian oscillator genes including Npas2, Bmal1, Per1-3, and Cry1-2, in combination with Ppara fluctuations [303].

Consistent with its role in the circadian regulation of lipid metabolism, PPAR $\alpha$ controls numerous genes implicated in lipid and cholesterol metabolism, and energy homeostasis. PPAR $\alpha$-driven cardiac regulation of enzymes involved in FA $\beta$-oxidation in the heart ensures metabolic homeostasis and heart performance [304,305]. The expression of FGF21 playing important roles in adaptation to fasting, such as lipolysis and ketogenesis is under the circadian influence of PPAR $\alpha$ [306]. Many of the metabolic genes, such as Srepb, Fas, and $\beta$-hydroxy $\beta$-methylglutaryl-CoA reductase (Hmg-CoAR), display daily fluctuations in mouse liver. The rhythmical expression of Fas and $H m g-C o A$ over the day presents a pattern that is opposite of that of Ppar $\alpha$. In the Ppar $\alpha$ KO mice, the rhythmical expression of lipogenic and cholesterogenic genes is dampened or eradicated. However, compared to WT mice, these changes are observed only during the active phase when food intake is high [307].

PPAR $\alpha$ is considered one of the marker genes of CR. Its expression is altered in CR in multiple organs and it likely mediates the response to metabolic changes as well as metabolic switch to low-energy conditions including mobilization of energy stores. PPAR $\alpha$ is also inseparably entwined in circadian clock control. Importantly, CR significantly enhances the circadian activity of PPAR $\alpha$ and, thus the oscillatory expression of its target genes [69]. Consequently, PPAR $\alpha$ is one of the best documented examples of a factor bridging CR and circadian rhythm.

\section{2. $P P A R \beta / \delta$}

In contrast to the expression pattern of PPAR $\alpha$ and PPAR $\gamma, \operatorname{PPAR} \beta / \delta$ is more ubiquitously expressed, with particularly high levels in several regions of the brain, kidneys, liver, skin, and gastrointestinal tract [308,309]. It is involved in cell proliferation, differentiation, tissue repair, placenta, and gut development, as well as energy homeostasis especially in muscle [280,310-316]. $\operatorname{PPAR} \beta / \delta$ stimulates energy expenditure by enhancing FA oxidation in skeletal muscle and adipose tissue, thereby protecting against diet-induced obesity and insulin resistance [317-320]. Moreover, hepatic deletion of PPAR $\beta / \delta$ reduces, while its activation increases, FA uptake in muscles, pointing at coordinated production and utilization of lipids in functionally interacting organs [321]. Exercise-induced glycogen exhaustion triggers PPAR $\beta / \delta$ activity in rat muscle stimulating changes in energy sources [322]. PPAR $\beta / \delta$ is particularly well known for increasing exercise capacity by promoting the switch to type I muscle fibers, which stimulates mitochondrial activity and fat oxidation resulting in improved endurance $[323,324]$. Furthermore, PPAR $\beta / \delta$ modulates feeding responses and its neuronal 
deletion leads to increased susceptibility to diet-induced obesity, elevated fat mass and decreased lean mass on low-fat diet, accompanied by abnormal responses to fasting [325].

\subsubsection{PPAR $\beta / \delta$ and Molecular Effectors of CR}

Only a few studies have documented a connection between mTOR and PPAR $\beta / \delta$ thus far. PPAR $\beta / \delta$ may impact mTOR activity by controlling FA metabolism and the production of phosphatidic acid, which directly activates the mTOR complex [326]. In non-small cell lung carcinoma (NSCLC) cells, the expression of PPAR $\beta / \delta$ is activated by nicotine through PI3K/mTOR [327], whereas GW501516, a PPAR $\beta / \delta$ agonist stimulates cell proliferation by inhibiting the expression of phosphatase and tensin homolog deleted on chromosome 10 (PTEN), which signals downstream to mTOR [328], picturing an interplay between the two pathways.

In models of metabolic syndrome [329], diabetes [330], and in overweight subjects [331], the GW501516 agonist of PPAR $\beta / \delta$ lowers plasma glucose and/or insulin levels. One of the mechanisms of energy status sensing by PPAR $\beta / \delta$ involves activation of cytosolic phospholipase A2 $\left(\mathrm{cPLA}_{2}\right)$ by glucose surplus, which leads to hydrolysis and peroxidation of arachidonic and linoleic acid, producing PPAR $\beta / \delta$ ligands [332]. Activated PPAR $\beta / \delta$ represses the $\beta$-cell mass and insulin secretion [333]. It prevents insulin resistance in adipocytes [334], human liver cells [335], and skeletal muscle cells [335,336]. Joint complementary effects of PPAR $\beta / \delta$ in distinct tissues involving its impact on carbohydrate catabolism in the liver and $\beta$-oxidation in muscle results in improved metabolic homeostasis and insulin sensitivity [337].

AMPK and PPAR $\beta / \delta$ interact directly in the muscle to enhance exercise performance [338]. AICAR, an activator of AMPK, increases endurance, but the combination of AICAR and GW0742, an agonist of PPAR $\beta / \delta$, significantly boosts the activity of the receptor and rises all running parameters. The mechanism behind involves a lowering in carbohydrate utilization with a parallel shift to fat as the main energy source in fatigued muscles [339]. Therefore, agonists of AMPK and PPAR $\beta / \delta$ are considered exercise mimetics [340].

Finally, PPAR $\beta / \delta$ increases transcription [341] as well as protein levels [342] of SIRT1. The regulation of SIRT1 and PPAR $\beta / \delta$ activity operates bidirectionally [342,343]. Moreover, PPAR $\alpha$ and PPAR $\beta / \delta$ stimulate SIRT1-dependent osteogenic differentiation [344,345], whereas PPAR $\gamma$ prevents it [346].

\subsubsection{PPAR $\beta / \delta$ in Circadian Rhythm}

In mice, the expression of $\operatorname{Ppar} \beta / \delta \mathrm{mRNA}$ oscillates daily in brown adipose tissue and muscle [288]. $\operatorname{PPAR} \beta / \delta$ regulates the diurnal expression of lipogenic genes including acetyl-CoA carboxylase 1 and 2 (Acc1 and $A c c 2$ ), Fas, and stearoyl-CoA desaturase-1 (Scd-1), during mouse feeding cycle [321]. Moreover, hepatic $P$ par $\beta / \delta$ is a target of mir-122 and likely mediates the impact of mir-122 on cholesterol and lipid metabolism. Importantly, mir-122 transcription is rhythmically regulated by REV-ERB $\alpha$ [347]. Finally, PPAR $\beta / \delta$ expression rhythmically changes in hamster $\mathrm{SCN}$ where it modulates glutamate release. Treatment with the PPAR $\beta / \delta$ agonist L-16504 enhances the phase delay of the locomotor response induced by a light pulse. This observation suggests that PPAR $\beta / \delta$ is mediating entrainment of the circadian clock by light (Figure 3) [348].

\subsection{PPAR $\gamma$}

PPAR $\gamma$ is primarily known as a master regulator of adipogenesis, a target of insulin-sensitizing, and anticancerogenic therapies [349-351]. It has been shown to impact several types of cancers by reducing cell proliferation [352-354], stimulating cell differentiation [352,355], triggering apoptosis [352,353,356], and inhibiting angiogenesis [357]. PPAR $\gamma$ contributes to several processes including adipogenesis and FA storage, inflammation, and lipid and glucose metabolism [349,358,359], long-chain FA processing in the intestinal epithelium [360], and control of adiposity via the sympathetic nervous system [361]. Classical full PPAR $\gamma$ agonists TZDs such as rosiglitazone (Avandia) and pioglitazone (Actos) are used to be applied in the therapy of metabolic diseases [362]. 
Remarkably, dual PPAR $\alpha / \gamma$ agonists have beneficial effects on both lipid and glucose metabolism. In addition to their antidiabetic properties, they also are hypolipemic, anti-inflammatory, hypotensive, and antiatherogenic, and exert anticoagulant effects [217,363-365]. Multiple natural compounds stimulate PPAR $\gamma$ expression and activity. They include nutrients, most importantly FAs and their metabolites. Furthermore, glutamine, curcumin, capsaicin, ginsenosides, and vitamin E impact PPAR $\gamma$ activity indirectly [366]. Importantly, bacterial metabolites and bacterial by-products [367-369], and specific bacterial strains in the gut microbiota also increase the expression and activity of PPAR $\gamma[368,370,371]$. A common side effect of treatment with TZDs is weight gain. HFD-related weight gain partly depends on the effect of neuronal PPAR $\gamma$ signaling which leads to limited thermogenesis and increased food intake [372,373]. Moreover, PPAR $\gamma$ plays role in regulating food intake by stimulating adipogenesis since WAT secretes endocrine and paracrine satiety mediators like leptin, adiponectin, and resistin [374].

\subsubsection{PPAR $\gamma$ and Molecular Effectors of CR}

Of all PPARs, the interplay of PPAR $\gamma$ with CR pathways has resulted in the richest set of evidence for an important role of PPAR $\gamma$ in the outcomes of CR. For instance, genetic variation in the Ppar $\gamma$ gene and its target gene Acsl5 are implicated in the extend of weight reduction upon CR [375]. In particular, six Ppary SNPs correlate with weight loss under CR [376]. The Pro(12) Ala substitution of Ppary reduces the binding affinity for PPRE and therefore, this PPAR $\gamma$ variant has a weaker transcriptional activity [377,378]. The Ppary (12)Ala allele confers resistance to CR-induced weight loss in obese women [375] whereas, following CR, female homozygotes for Ala(12)Ala regain more body weight than Pro (12) Pro homozygotes [379]. Further, Ppar $\gamma$ polymorphism is linked with BMI changes due to fat intake [380,381], diet FA composition [382], and plasma TG response to $\omega 3$-FA supplementation [383].

PPAR $\gamma$ is well known as a regulator of insulin sensitivity and TZD drugs ameliorate insulin resistance by reducing plasma glucose and they improve the lipidemic profile in type 2 diabetes (T2D) and in obese subjects without diabetes [384]. TZDs also sustain the function of pancreatic $\beta$-cell thereby reducing T2D incidence [385,386]. In addition to TZDs, several other PPAR $\gamma$ agonists including FMOC-L-leucine (F-L-Leu) [387], INT131 besylate [388], quercetin, and kaempferol [389,390] improve insulin and glucose management. PPAR $\gamma$ exerts its insulin-sensitizing effects in several ways. It promotes functional WAT necessary for proper glucose homeostasis as evinced by insulin resistance upon both partial and generalized lipodystrophies [391,392] as well as by improved glycemic control following PPAR $\gamma$-triggered fat mass generation [393]. Moreover, the magnitude of PPAR $\gamma$-elicited insulin sensitization is proportional to the reduction of lipid accumulation in skeletal muscle [394]. Accordingly, various point mutations in the Ppar $\gamma$ gene, which result in familial partial lipodystrophy are accompanied by severe insulin resistance [395-399]. Consistently, dominant-negative mutations in human Ppar $\gamma$ causes metabolic syndrome, insulin resistance, and diabetes at a young age [400,401]. Further, the TZD Pioglitazone impacts the insulin signaling pathway to improve insulin sensitivity [402]. In fact, PPAR $\gamma$ increases the expression of factors in the insulin signaling pathway, including IRS-1 [403], IRS-2 [404], the p85 subunit of PI3K [405], and Cbl-associated protein (CAP) [406,407]. In muscle cells and adipocytes, PPAR $\gamma$ activation increases the expression and translocation of GLUT1, GLUT2, and GLUT4 to the cell membrane stimulating glucose uptake and lowering plasma glucose concentrations [408-410]. Further, PPAR $\gamma$ manages the intercellular glucose levels by regulating the expression of genes connected with insulin-stimulated glucose disposal [403-407]. The insulin-sensitizing effect of PPAR $\gamma$ ligands relies on a reduction in local and systemic cytokine production [411] and counteracting tumor necrosis factor $\alpha$ (TNF $\alpha$ ) effects [412]. Moreover, PPAR $\gamma$ enhances the plasma levels of adipocytokines, among them adiponectin, which improves insulin sensitivity together with increased free FA oxidation and reduced gluconeogenesis $[413,414]$. In hepatocytes, Akt2 a downstream factor of insulin signaling stimulates the expression and activity of PPAR $\gamma$ leading to stimulation of glycolysis and lipogenesis [415]. In addition, an interaction between FOXO1 and PPAR $\gamma$ affects insulin sensitivity in adipocytes. FOXO is a 
transcriptional repressor of Ppar $\gamma$. It binds to its promoter and may also reduce the transcriptional activity of PPAR $\gamma$ by direct protein-protein interaction [416-418].

Importantly, the application of PPAR $\gamma$ antagonists can also improve the metabolic profile [419,420], whereas $\mathrm{Ppar}^{+/-}$haplodeficiency promotes insulin sensitivity compared with WT animals [421,422]. Similarly, the genetic variants Pro(12)Ala (heterozygotes) and Ala(12)Ala (homozygotes) with reduced transcriptional activity cause leanness and improved insulin sensitivity [377,423,424]. Therefore, a carefully calibrated dose of PPAR $\gamma$ activity is required for optimal insulin sensitivity [425].

The inhibition of mTORC1 disturbs adipogenesis and adipocyte maintenance in vitro [120,426-429], at least partly via PPAR $\gamma[120,121,430,431]$. Consistently, the application of rapamycin reduces coactivation of some transcription factors (see above) which control lipid metabolism, including PPAR $\gamma$ and PGC $-1 \alpha$ [432-434]. mTORC1 may activate PPAR $\gamma$ through SREBP-1, which produces endogenous PPAR $\gamma$ ligands $[435,436]$ as well as regulates the hypolipidemic and lipogenic effects of PPAR $\gamma$ [431]. Reciprocally, PPAR $\gamma$ stimulates mTORC1, TG-derived FA uptake, lipoprotein lipase activity, and consequent accumulation of lipids in subcutaneous WAT and BAT. Impact of this pathway by chronic mTOR inhibition results in hyperlipidemia. Rapamycin resistance can be obtained by PPAR $\gamma$ activation, whereas treatment with rapamycin increases both expression and activation of PPAR $\gamma$ in mouse models of breast cancer [437].

PPAR $\gamma$, similarly to what we discussed for PPAR $\alpha$, also controls autophagy, which is the major cellular process associated with mTOR. PPAR $\gamma$ activation increases autophagy, but its inactivation lessens it [438,439]. Cell cycle arrest and stimulation of autophagy are two major processes by which PPAR $\gamma$ stops cancer cell progression, as evinced in the colon [440], breast [441,442], bladder [443], and adrenocortical [444] cancer cell lines. Contrariwise, in neurons [445,446] and macrophages [447] $\operatorname{PPAR} \gamma$ shows anti-autophagic properties.

PPAR $\gamma$ agonists activate AMPK in many cell lines [448-452], tissues ex vivo [453,454], in animals [455-457], and humans [458] and improve glucose and fat management. TZDs increase glucose uptake in the liver, adipose tissue, skeletal, and cardiac muscle $[454,457,459]$ as well as reduce insulin resistance via AMPK activation $[448,453,460,461]$. Agonists of PPAR $\gamma$ stimulate AMPK to enhance expression of adiponectin receptors [458], increase FA oxidation and insulin-stimulated glucose disposal [448], $\beta$-cell metabolism [453], and insulin secretion [461]. In addition to metabolic functions, AMPK facilitates the anti-inflammatory activities of PPAR $\gamma[451,452]$. Reciprocally, while constitutively active or dominant-negative AMPK $\alpha$ reduces PPAR $\gamma$ activity similarly to AICAR and metformin, compound C, an AMPK inhibitor enhances basal and rosiglitazone-stimulated PPAR $\gamma$ activity [462].

PPAR $\gamma$ and SIRT1 functionally cooperate in that PPAR $\gamma$ interacts with SIRT1 to inhibit its activity and by binding to the Sirt1 promoter to repress its activity [463]. Furthermore, pioglitazone blocks NF- $\mathrm{KB}$ activation through the AMPK-SIRT1/p300 pathway [464], and SIRT1 inhibits PPAR $\gamma$ activity by docking with the PPAR $\gamma$ corepressors NcoR and SMRT $[465,466]$. Consequently, SIRT1 counters adipogenesis, stimulates lipolysis, and the release of fat from mature adipocytes [465,467]. During fasting, SIRT1 represses PPAR $\gamma$ and thereby stimulates fat mobilization [465]. Accordingly, the mobilization of FAs from adipose tissue during fasting is altered in SIRT1 ${ }^{+/-}$mice [465].

\subsubsection{PPAR $\gamma$ in Circadian Rhythm}

As an important factor in response to CR and metabolic processes, PPAR $\gamma$ is inevitably implicated in circadian rhythm regulation (Figure 3). Bmal1 [468], Rev-Erb $\alpha$ [469], and Ror $\gamma$ [470] are induced by PPAR $\gamma$. 15-deoxy-Delta12,14-prostaglandin J2 (15d-PGJ2), a natural ligand of PPAR $\gamma$, promotes the rhythmic expression of endogenous clock genes in NIH3T3 cells. Moreover, 15d-PGJ2 transiently induces Cry1, Cry2, and Ror $\alpha$ expression. However, the 15d-PGJ2-induced entrainment signaling pathway seems to be PPAR $\gamma$-independent [471]. Similarly, PGC- $1 \alpha$, which interacts with PPAR $\gamma$, is rhythmically expressed in mouse liver and muscle and it stimulates the expression of Bmal1 and Rev-erb $\alpha$ [169]. PGC $-1 \alpha$ KO mice are affected in their locomotor activity and are characterized by an 
altered daily oscillation of body temperature and energy metabolism, in association with the abnormal expression pattern of metabolic and clock genes [169].

In the whole-body Ppary deletion induced in the adult mouse (EsrCre/flox/TM mouse), circadian variations in oxygen consumption, $\mathrm{CO}_{2}$ production, food and water intake, locomotor activity, and cardiovascular parameters are repressed and the rhythmicity of the canonical clock genes in adipose tissues and liver, but not skeletal muscles or the kidney, are impaired indicating disturbed circadian rhythms at both behavioral and cellular levels [472]. Ppar $\gamma$ shows circadian expression patterns in mouse fat, blood vessels, and liver $[288,468]$. The Ppar $\gamma$ expression in the aorta is robustly rhythmic with a more than 20-fold change during the day/night cycle [468]. Ppar $\gamma$ Tie2Cre/flox and SM22Cre/flox KO mice showing Ppary deletion in the endothelial and vascular smooth muscle cells respectively, are characterized by reduced circadian oscillations in heart rate and blood pressure, which is associated with diminished changes in urinary norepinephrine and epinephrine excretion. In these mice, the rhythmicity of the canonical clock genes, including Bmal1 is compromised [468]. In addition, pioglitazone has been shown to restore the nocturnal blood pressure decline and transform blood pressure from a nondipper to a dipper type in type 2 diabetic patients [473].

Similarly, like PPAR $\gamma$, the circadian clock is important for adipose tissue functions and fat metabolism. The core clock proteins regulate all aspects of lipid management by cyclic repression of several genes, including those coding for rate-limiting lipolytic enzymes. Consequently, the disruption of the circadian clock causes aberrant dietary lipid absorption, lipid transport, fat storage, and triglyceride levels [474]. The expression of Rev-Erb $\alpha$ is stimulated by PPAR $\gamma$ during adipogenesis in rat perirenal and epididymal adipose tissues, as well as in 3T3-L1 adipocytes. REV-ERB $\alpha$ facilitates the expression of PPAR $\gamma$ target genes and, accordingly, ectopic expression of Rev-Erb $\alpha$ in 3T3-L1 cells potentiates rosiglitazone PPAR $\gamma$ agonist-induced adipocyte differentiation [469,475]. Therefore, double KO of Rev-erb $\alpha$ and Rev-erb $\beta$ causes deregulated lipid metabolism [476]. Similarly, Ror $\gamma$ is induced during adipocyte differentiation following the induction of Ppar $\gamma$ in D1 and 3T3-L1 cells and functions as an active transcription factor [470]. Also, BMAL1 via WNT signaling controls circadian regulation of adipocyte differentiation $[477,478]$ and embryonic fibroblasts from Bmal1 $\mathrm{KO}$ mice fail to differentiate into adipocytes, whereas over-expression of Bmal1 in adipocytes increases lipogenesis [477]. Nocturnin, which is controlled by the clock, manages the circadian dietary fat uptake and clock KO mice exhibit altered dietary lipid trafficking [479], whereas PPAR $\gamma$ also plays a role in the uptake of long-chain FA in the intestine [360]. Furthermore, CR increases the amplitude of the circadian clock gene timeless (Tim) cycling, which has been implicated in daily fluctuations of several medium-chain triglycerides under CR. Overexpression of Tim in peripheral tissues improves oscillatory amplitude, enhances fat metabolism, which extends lifespan under ad libitum conditions [480].

HFD induces robustly the hepatic daily expression pattern of Ppar $\gamma$. In HFD-fed mice, the levels of PPAR $\gamma$ protein are elevated, but do not show daily oscillations. Interestingly, however, nuclear and chromatin-bound PPAR $\gamma$ shows a significant circadian oscillation in these mice. Accordingly, PPAR $\gamma$ targets gain rhythmicity after acute HFD feeding [481]. Furthermore, the HFD-related hepatic fluctuations of PPAR $\gamma$ activity are driven by microbial communities in the gut as documented by antibiotic treatments that repress PPAR $\gamma$-driven transcription in the liver. Therefore, HFD-induced remodeling in the gut microbiota mediates $\operatorname{PPAR} \gamma$-driven modulation of the host liver clock, resulting in adjusted circadian transcription [482]. 


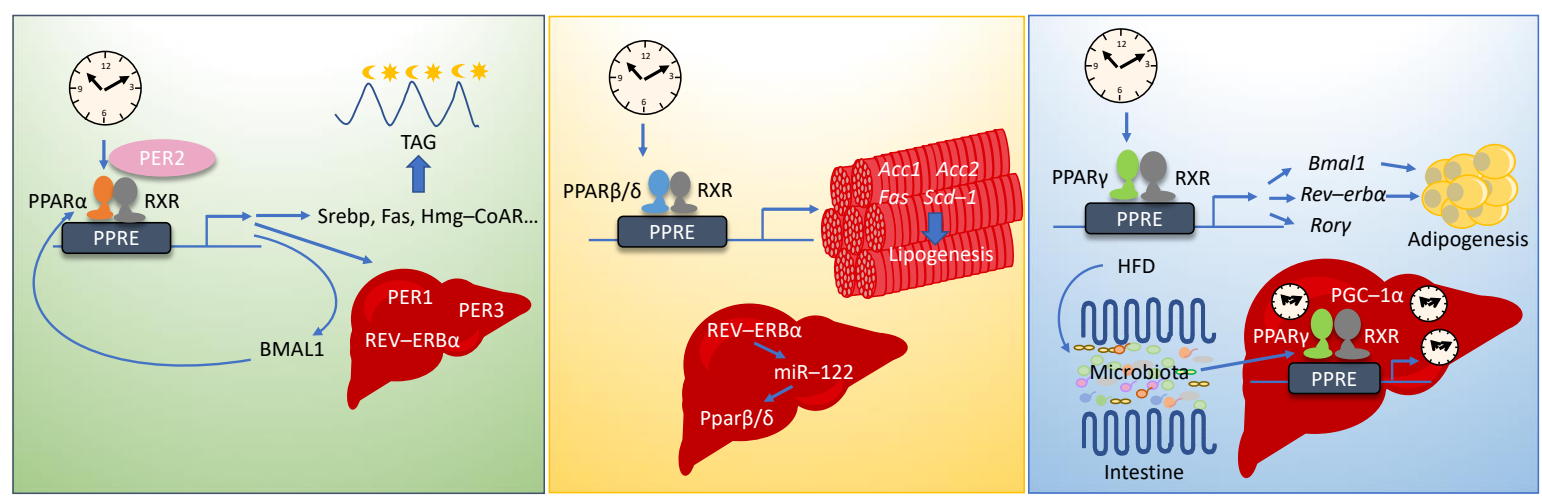

Figure 3. The role of PPARs in circadian rhythm. The levels of all PPARs are regulated according to daily oscillations. PPAR $\alpha$ targets the expression of lipid metabolism-related genes resulting in rhythmic changes in the levels of triacylglycerols (TAG). PPAR $\alpha$ interacts directly with PER2 to modulate gene expression. In the muscle, PPAR $\beta / \delta$ regulates the expression of lipogenic genes in a rhythmic manner. PPAR $\beta / \delta$ is also an indirect target of the circadian clock via miR-122. PPAR $\gamma$ regulates expression of core circadian genes including Bmal1 and Rev-erb $\alpha$, which support adipogenesis. In the liver, PPAR $\gamma$ also mediates the action of circadian triggers derived from gut microbiota in response to high-fat diet (HFD). PPARs bind to PPRE as PPAR:RXR heterodimers. Abbreviations: Acc-acetyl-CoA carboxylase; Fas-fatty acid synthase; Hmg-CoAR- $\beta$-hydroxy $\beta$-methylglutaryl-CoA reductase; PGC-1 $\alpha$-peroxisome proliferator-activated receptor $\gamma$ coactivator $1 \alpha$; PPRE-PPAR response element; RXR-retinoid X receptor; Scd-1-stearoyl-CoA desaturase-1; Srebp-sterol regulatory element-binding protein 1.

\subsection{Systemic Impacts of $C R$ in the Context of Circadian Rhythm and PPAR Activities}

\subsubsection{Modulation of the Oxidative Status}

CR exerts major beneficial effects through reducing ROS levels [483-485] in three distinct ways: (i) reduction of oxygen free-radical production by slowing metabolism, (ii) increasing rate of ROS neutralization, and (iii) accelerating the repair of ROS-damaged molecules [486-490]. In vivo, concentrations of ROS and several products of oxidation oscillate in a circadian manner in tissues and blood. The circadian clock is a major regulator of ROS homeostasis as proven by the fact that circadian protein mutants present increased levels of ROS and oxidative damage [491,492] and continuous light diminishes or abolishes the circadian rhythms of SOD, glutathione reductase (GR), and catalase (CAT) [493]. CAT activity peaks in humans at the beginning of the light phase in plasma [494], whereas in mice it culminates in the middle of the dark phase in the liver and kidneys [495] in accordance with eating patterns of these species. The antioxidant proteins peroxidoxins (PRX) show distinct daily fluctuation patterns in the SCN and the liver of Syrian hamsters [493] and, correspondingly, their day time expression changes are accompanied by differences in DNA damage, lipid peroxidation, and protein oxidation [493,496-499]. In the rat cerebral cortex, SOD activity peaks in the dark phase, correlating with the highest level of malondialdehyde, which is build up in the process of lipid peroxidation [500]. In addition to the cerebellum, both $\mathrm{Cu} / \mathrm{Zn}$ and $\mathrm{Mn}-\mathrm{SOD}$ expression levels show diurnal rhythmicity in the rat intestine and lung [501]. These fluctuations may depend on Per 2 since Per $2 \mathrm{KO}$ mice have a lower amplitude of oscillations in hepatic $\mathrm{Cu} / \mathrm{Zn}$ SOD expression and activity [502]. Along a similar line, $\mathrm{KO}$ of both Per1 and Per 2 results in a $4 \mathrm{~h}$ shift in the peak of $\mathrm{Cu} / \mathrm{Zn}$ SOD expression, when compared to WT mice [502].

Reduced glutathione (GSH), in contrast to oxidized GSH (GSSG), is one of the most important non-enzymatic antioxidants. GSH acts as a scavenger of free radicals, supports the reduction of $\mathrm{H}_{2} \mathrm{O}_{2}$, and takes part in detoxification. Circadian oscillations have been demonstrated for GSH and the expression of enzymes necessary for the functional GSH system, including those involved in GSH reduction (GSH reductase (GR)], oxidation of GSH by reduction of $\mathrm{H}_{2} \mathrm{O}_{2}$ [GSH peroxidase (GPx)], 
and conjugation of GSH [GSH S-transferase (GST)] to various electrophilic substrates [499,503-508]. The reduction of GSSG to GSH is necessary to maintain the cellular redox status. This process involves $\mathrm{NADP}^{+}$and its redox partner NADPH, which were mentioned previously as they are inseparably connected with SIRTs. Moreover, in cultured rat fibroblasts high $\mathrm{NAD}^{+}$and $\mathrm{NADP}^{+}$levels decrease the binding capacity of CLOCK:BMAL1 heterodimers to E-box targets, whereas high levels of the reduced NADH and NADPH strongly enhances their binding in concert with BMAL1 acetylation, leading to increased expression of Pers, Crys, and other circadian genes [202]. Additionally, SIRT1 is also connected with another important marker of the circadian rhythm, melatonin. Melatonin acts as a synchronizer in mammals and provides temporal feedback to oscillators within the SCN and has been proven to display antioxidant properties [509]. Moreover, melatonin inhibits the expression and activity of SIRT1 [510]. Therefore, there is a complex connection between CR and circadian rhythm involving the redox status, SIRT1, and melatonin, at the border of oxidative and circadian systems.

In Ppard KO mice, increased oxidative stress occurs at an earlier age compared to WT animals [226] and dosing PPAR $\alpha$ agonists restores the redox balance in aged mice [226]. WY-14643 and fenofibrate provide protections against acetaminophen-induced hepatotoxicity by upregulating UCP-2, thereby reducing mitochondrial ROS production [511]. In a gentamicin-induced model of oxidative stress, PPAR $\alpha$ and PPAR $\gamma$ agonists (fenofibrate, pioglitazone, tesaglitazar) prevents toxicity by elevating the expression of Sod-1, glutathione peroxidase 1 and 3 (GPx1/3), Cat, and uncoupling protein 2 (Ucp2) [512].

PPAR $\gamma$ also regulates the expression of several antioxidant and pro-oxidant enzymes, as well as oxidative stress-related proteins, including GPx3 [513], CAT [514,515], and MnSOD [516]. Therefore, heart-specific PPAR $\gamma \mathrm{KO}$ mice exhibit extensive oxidative damage accompanied by lower levels of MnSOD and elevated $\mathrm{O}_{2}^{-}$levels in cardiac muscle [516]. Furthermore, PPAR $\gamma$ reduces the expression of inducible nitrogen monoxide (NO) synthase (iNOS) and stimulates endothelial NO synthase (eNOS) [517-521]. Conversely, the aorta of endothelial-specific PPAR $\gamma$ KO mice releases less NO than in WT animals, leading to an increase in oxidative stress [519]. Further, activation of PPAR $\gamma$ upregulates UCP2 expression in rats [522], which prevents $\mathrm{O}_{2}{ }^{-}$accumulation in the mitochondria and aids in the export of ROS from mitochondrial to the cytosol [523]. Moreover, CD36, the main target gene of PPAR $\gamma$, supports the recognition and internalization of oxidized lipids [524-526]. Finally, PPAR $\gamma$ also increases Bcl-2 levels and thus, protects cardiomyocytes and glial cells from apoptosis triggered by oxidative stress [527,528].

Nuclear factor erythroid 2-related factor 2 (NRF2), a redox-sensitive transcriptional factor that serves as the master regulator of the oxidative stress response, cryoprotection against oxidative as well as electrophilic stress and takes part in inflammation suppression [529] contains PPREs in its gene promoter [530,531]. Reciprocally, NRF2 also binds the upstream promoter region and induces PPAR $\gamma[530,532]$ creating a positive feedback loop between PPAR $\gamma$ and NRF2. Interestingly, BMAL1 directly controls the expression of NRF2 [533], Hence, there is an overlap between the ability of PPARs to control oxidative stress and the effects of CR and circadian rhythm (Figure 4). 


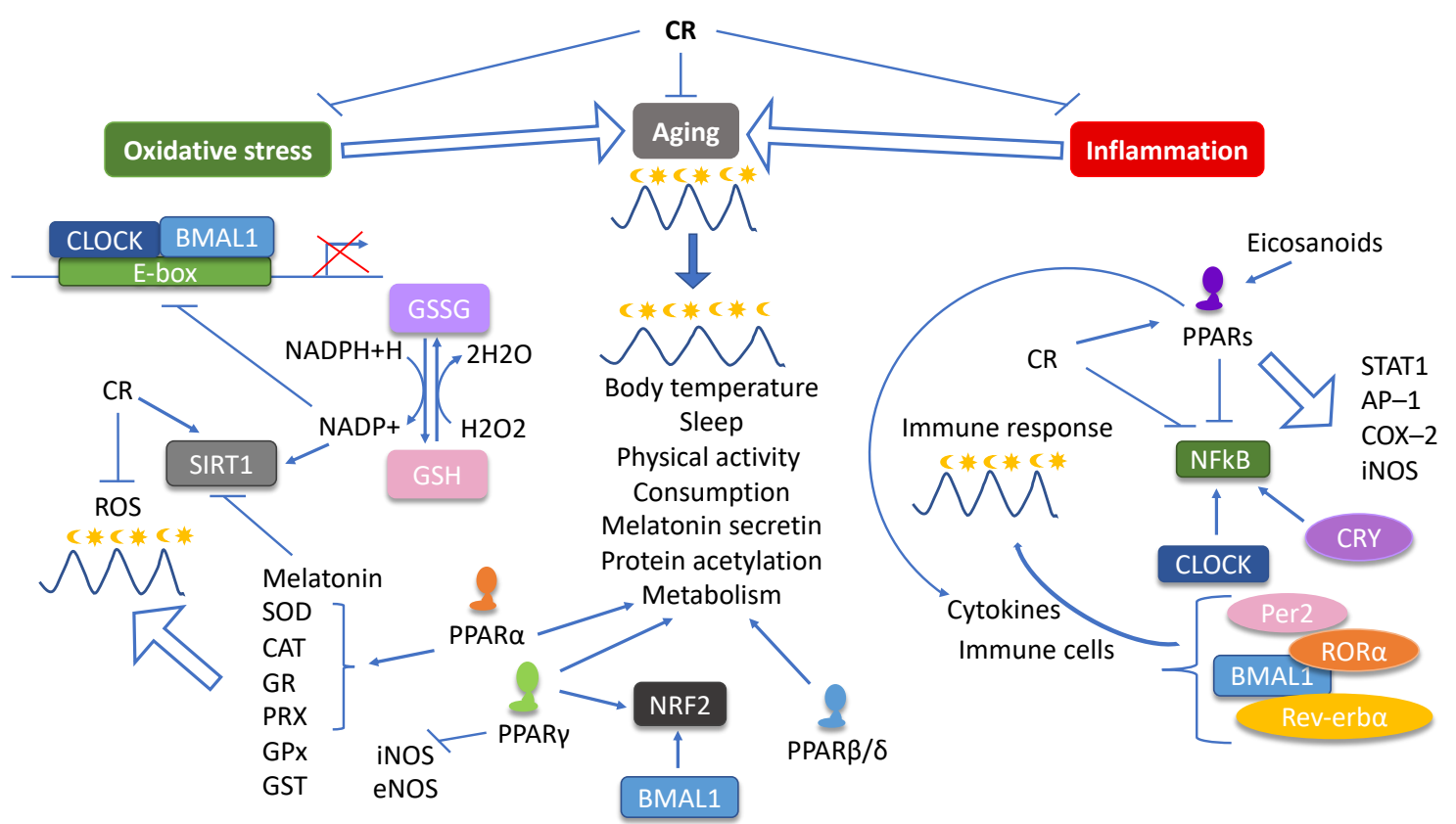

Figure 4. PPARs contribute to the processes regulated by $C R$ and circadian rhythm at the whole-body level. CR exerts its beneficial effects by reducing oxidative stress, delaying aging, and inhibiting inflammation. Circadian rhythm affects all of these processes. PPARs regulate the expression of antioxidative enzymes, inflammatory cytokines, and metabolic processes. For the effects of SIRT refer to Figure 2. Abbreviations: AP-1-activating protein-1; CAT-catalase; COX-2—cyclooxygenase-2; eNOS—endothelial NO synthase; GPx-GSH peroxidase; GR-GSH reductase; GSH — glutathione; GSSG—oxidized glutathione; GST_GSHS-transferase; iNOS—inducible NO synthase; NRF2-nuclear factor erythroid 2-related factor 2; PRX-peroxiredoxins; ROS—reactive oxygen species; SOD—superoxide dismutase; STAT1—signal transducer and activator of transcription 1.

\subsubsection{Reduction of Inflammation}

The immune system as one of the key factors indispensable for survival has been intensively investigated in the context of circadian rhythms. The expression levels of toll-like receptors (TLRs) display significant circadian fluctuations in the mouse jejunum [534]. In the spleen and natural killer cells of rats, transcription of interferon $\gamma(\mathrm{I} f n \gamma)$, granzyme B (GrB), perforin (Prf), and Tnf $\alpha$ oscillate showing the highest expression at the break of the dark and the light phase which coincides with the cytolytic activity of splenic natural killer cells [535-537]. Similarly, the migration of lymphocytes through lymph nodes is regulated by circadian rhythm and peaks at the beginning of the active phase in mice [538]. Accordingly, the timing of triggering and generating immune response is decisive in the regulation of the efficiency of the reaction. After infection of the mouse gastrointestinal tract with Salmonella enterica serovar Typhimurium there is a more efficient bacteria clearance for infection done $4 \mathrm{~h}$ after the beginning of the dark phase compared to $4 \mathrm{~h}$ into the light phase. Moreover, levels of antimicrobial peptide lipocalin-2 in the intestine are higher during the day than during the night [539]. Importantly, PPAR $\gamma$ and lipocalin-2 cooperate in response to bacterial infection in the intestine [540]. In the case of sepsis, the timing of the disease induction impacts the severity of the disease and coincides with the oscillations in TLR9 expression [541].

The central pacemaker can also regulate oscillations of inflammatory factors in peripheral organs as local splenic sympathectomy alters daily variations of cytokines, TNF $\alpha$, and cytolytic factors, GRB, and PRF, in natural killer cells and splenocytes [542]. A lesion in the SCN leads to loss of daily variations in serum histamine, MCP-1 (CCL2), and IL-6 levels in mice [543] and dysregulated immune response with higher levels of cytokines after administration of lipopolysaccharide (LPS) in rats [544]. Moreover, night administered LPS increases SCN basal neuronal activity [544] and induces more 
severe responses in body temperature and cytokine production than LPS given in the rest period [544]. However, the inflammatory response of the mouse lung to LPS is strongest during the day compared to the night [545]. Finally, rodents with a reversed feeding schedule, consuming during the light phase, and fasting at night, show inadequate inflammatory response to LPS in association with elevated TNF $\alpha$ and IL-6 levels and increased mortality [546,547].

Clock genes have been shown to modulate the expression of multiple inflammatory cytokines. CRY affects TNF $\alpha$, IL1 $\beta$, and Il-6 [548], ROR $\alpha$ impacts Il-1 $\beta$, and Il-6 [548], PER2 modulates daily rhythms of IFN $\gamma$ [549], and Il-1 $\beta$ [550], Rev-ERB $\alpha$ regulates IL-6 [551], MCP-1 as well as TH17 cells [552], while Bmal1 regulates diurnal oscillation of Ly6C hi inflammatory monocytes [553] and reduces monocyte recruitment [554]. Consequently, Clock KO mice exhibit reduced cytokine production in macrophages in response to the LPS challenge or Salmonella Typhimurium infection [539]. On the contrary, deletion of the negative clock arm Ror $-\alpha$ in mice leads to a stronger LPS-induced inflammation with higher levels of Il-1 $\beta$, IL-6, and macrophage inflammatory protein-2 in bronchoalveolar lavage fluids from mice lungs [548]. Moreover, T and B cell development is defective in these mice while mast cells and macrophages produce an increased amount of TNF $\alpha$ and IL-6 upon activation [555]. Per2 KO mice are more resistant to the LPS challenge compared to WT mice [550]. KO or silencing of Cry1 and Cry 2 also leads to increased inflammation, a permanent elevation of proinflammatory cytokines in a cell-autonomous manner, and constitutive activation of NF- KB and PKA signaling [556]. Importantly, CLOCK is required for acetylation of $\mathrm{p} 65$, a key event for $\mathrm{NF}-\kappa \mathrm{B}$ transactivation and downstream cytokine production [557]. NF- $\mathrm{KB}$ is a transcriptional regulator of major importance and its action is usually pro-inflammatory and pro-oxidant. NF- $\mathrm{kB}$ induces the expression of the inflammatory cytokines sIL-1 $\beta, \mathrm{IL}-6$, and TNF $\alpha$, as well as the proinflammatory enzymes cyclooxygenase-2 (COX-2) and iNOS. However, it can also affect the expression of Sod and other anti-inflammatory genes [558-563]. CR exhibits a broad anti-inflammatory effect and it acts, among others, through NF- $\mathrm{B}$ and I $\kappa \mathrm{B}$ to blunt age-triggered increases in COX-2 levels and activity. CR suppresses the generation of iNOS, IL- $\beta$, IL-6, TNF $\alpha$, and prostanoids, such as TXA 2, prostacyclin 2, and prostaglandin E2 [59,485] while dampening aging-related reduction of PPAR expression and activity [229]. PPARs interfere with several pro-inflammatory mediators including $\mathrm{NF}-\kappa \mathrm{B}$, signal transducer and activator of transcription 1 (STAT1), and activating protein-1 (AP-1) [564-567] inhibiting the expression of genes coding for inflammatory proteins, such as COX-2, iNOS, cytokines, metalloproteases, and acute-phase proteins [520,565]. Moreover, inflammatory eicosanoids including prostaglandins and leukotrienes act as ligands for PPARs [568,569]. However, each PPAR exhibits a set of distinct anti-inflammatory activities [569].

The anti-inflammatory properties of PPAR $\alpha$ are mostly based on its interaction with NF- $\kappa \mathrm{B}$. Accordingly, PPAR $\alpha$ KO results in premature oxidative stress and an aggravated inflammatory response as well as a stronger age-dependent increase in oxidative stress and NF- $\kappa \mathrm{B}$ activity [226,570]. In agreement with these observations, agonists of PPAR $\alpha$ reduce the activity of $N F-K B$ and the spontaneous generation of inflammatory cytokines [226,571]. Importantly, high doses of PPAR $\alpha$ ligands induce $\mathrm{NF}-\kappa \mathrm{B}$, whereas low amounts reduce $\mathrm{NF}-\kappa \mathrm{B}$ activation [226]. PPAR $\alpha$ contributes to the anti-inflammatory properties of $C R$ by reducing the expression of acute-phase genes $(C 4 b p, C 9$, Mbl1, Orm1, and Saa4) responsive to inflammatory cytokines [232].

$\operatorname{PPAR} \beta / \delta$ is also capable of regulating $\mathrm{NF}-\kappa \mathrm{B}$. The activation of PPAR $\beta / \delta$ protects skeletal muscle against metabolic disorders also by means of counteracting the diet-induced activation of $\mathrm{NF}-\kappa \mathrm{B}$ as well as expression of iNOS and intercellular-adhesion-molecule-1 (ICAM-1) [572]. GW0742, an agonist of PPAR $\beta / \delta$, inhibits LPS-triggered TNF $\alpha$ secretion. Accordingly, overexpression of PPAR $\beta / \delta$ substantially inhibits TNF $\alpha$ expression, while the absence of PPAR $\beta / \delta$ enhances LPS-induced TNF $\alpha$ production in cultured cardiomyocytes [573]. In the intestine, PPAR $\beta / \delta$ dampens inflammatory signaling and therefore it can suppress inflammatory bowel disease [574].

PPAR $\gamma$ is one of the most potent anti-inflammatory factors with extensive research proving its properties. PPAR $\gamma$ agonists diminish inflammatory bowel disease symptoms and are instrumental 
in the therapy of ulcerative colitis and Crohn's disease [540,575-580]. The ligands of PPAR $\gamma$ prevent macrophage activation, promote macrophage conversion into the non-inflammatory type M2, and inhibit the production of inflammatory cytokines in macrophages and dendritic cells. Consequently, PPAR $\gamma$ KO mice show increased susceptibility to infection $[520,565,581,582]$ whereas, mice specifically deficient in colonic PPAR $\gamma$ exhibit more acute symptoms of infectious colitis [540] and are resistant to colitis therapy using conjugated linoleic acid [583]. Ppar $\gamma$ polymorphism is associated with changes in the onset of diseases with an inflammatory background including multiple sclerosis [584], T2D [424], vascular morbidity, and mortality [585], as well as colorectal cancer risk [586,587]. PPAR $\gamma$ exerts its anti-inflammatory properties by inhibiting the expression of inflammatory genes encoding cytokines, metalloproteases, and acute-phase proteins, and affecting multiple signaling molecules including p53 [588], Bcl2 [356], c-Myc, [589], Cox-2 [590,591], iNOS [592], and Apc/ $\beta$-catenin [593,594]. Most relevantly, PPAR $\gamma$ inhibits NF- $\mathrm{KB}$, and NF- $\mathrm{KB}-$ driven transcription [356,591]. Contrariwise, NF- $\mathrm{KB}$ reduces the transcriptional activity of PPAR $\gamma$ via a mechanism that involves HDAC3 $[595,596]$. Therefore, NF- $\mathrm{KB}$ seems to be a universal inflammatory factor connecting circadian rhythm, CR, and all of the PPARs (Figure 4).

\subsubsection{Prevention of Aging}

Circadian clocks have been implicated in the control of aging and aging-associated pathologies via regulation of oxidative stress, cell cycle, cell death, and DNA damage response [597]. Importantly, aging is accompanied by a shift in the phase and a decrease in amplitude of rhythmic oscillations [598-601]. In mice, age-dependent degradation of neuronal activity rhythms in the SCN results in the disruption of the physiological ability to entrain to external light cues, and approximately 20 times reduced sensitivity to the synchronizing effect of light compared to young animals; this leads to an alteration of rhythmic behavior [602-606]. Circadian rhythm-related changes during aging include body temperature, activity-wakefulness, locomotor activity patterns, and drinking behavior. In humans, aging is linked with a phase advance in the rhythms of body temperature and melatonin secretion as well as the earlier habitual time of sleeping and disturbed sleep [607,608]. Further, age alters the $24 \mathrm{~h}$ expression profile of Clock and Bmal1 in the hamster SCN [609] and results in alterations in the circadian transcriptome. The decline occurs in a tissue-specific manner, as documented by the comparison of transcriptional patterns in the liver versus epidermal and skeletal muscle stem cells [70].

Bmal1 $\mathrm{KO}$ mice have reduced lifespans and display various symptoms of premature aging including sarcopenia, cataracts, lesser subcutaneous fat, and organ shrinkage [13]. Deficiency of CLOCK also impacts longevity with the average and maximum lifespan of Clock KO mice being reduced by $15 \%$ and $20 \%$, respectively, compared to WT mice. This phenotype is accompanied by a high rate of development of age-related pathologies, cataracts, and dermatitis [11]. However, the mice do not develop the premature aging phenotype that characterizes Bmal1 KO mice. Based on wheel-running activity, the circadian rhythm in Per1, $2 \mathrm{KO}$ mice is out of control. These animals also display signs of premature aging including loss of soft tissues and kyphosis, a more rapid decline in fertility and litter size in each successive breeding, as well as a significant increase in neoplastic and hyperplastic phenotypes [610]. Per 1 and Per2 were proposed as longevity-associated candidate genes based on (i) the KO phenotype in mice, (ii) comparison of the activity of a group of genes with differential expression in several tissues such as the liver, brain, skeletal muscles of mice subjected to CR and (iii) Per gene expression in the long-lived dwarf mice [610,611]. In golden hamsters carrying a $20 \mathrm{~h}$-period mutation, tau, resulting in $24 \mathrm{~h}$ light-dark cycles, life span is shortened. However, in aged animals, longevity can be extended by fetal suprachiasmatic implants which restore higher amplitude rhythms [612-614].

Oscillation disturbance by weekly reversal of the light-dark cycle reduces the survival time of cardiomyopathic hamsters [615]. Transplanting fetal SCN to an old hamster with weak behavioral rhythms restores robust rhythmicity in the transplanted hosts [616], triggers a greater response to the phase-shifting effects of triazolam [617], and increases lifespan by 4 months [612]. In humans, a disrupted circadian rhythm in night-shift workers leads to metabolic disorders, 
increased incidence of cancer, hormone imbalance, gastrointestinal abnormalities, cardiovascular diseases, reproductive aberrations, sleep and psychological disorders including depression and anxiety [618].

In young mice, 2626 liver genes present a rhythmic expression, while in old mice this number is reduced to 1664 genes, including 1575 genes that are rhythmic in both groups and comprise the core clock genes. CR increases the number and amplitude of rhythmic genes in both young and old mouse livers [70]. Besides gene expression, also global protein acetylation is highly circadian. The acetylation rhythm is dampened in aged mice and can be rescued by CR [70]. Moreover, in aging epidermal stem cells (epSCs) and skeletal muscle stem cells (muSCs), CR maintains or restores rhythmic homeostatic functions [619]. As in mice, CR in Drosophila enhances the amplitude of cycling of most circadian clock genes, including Tim, in peripheral tissues [480]. Per and Tim KOs attenuate the CR-dependent changes in lifespan extension and fat metabolism [480]. Similarly, 30\% CR does not increase the lifespan or have an impact on the physiology of Bmal1 $\mathrm{KO}$ mice [71]. Therefore, some of the circadian clock genes are necessary for the full benefits of CR.

Aging is associated with decreased metabolic rate, impaired mitochondrial function, reduced insulin resistance, dysfunctional lipid metabolism, immunosenescence, increased oxidative stress, and lowered hormonal secretion [620-622]. Glucose metabolism and insulin sensitivity maintenance is a key feature of the anti-aging actions of CR $[54,75]$. In fact, genes connected with the insulin/IGF-1 signaling pathway, which include PPARs, have been proposed as longevity candidate markers $[77,78,623]$. Similarly, healthy adipose tissue has also been directly associated with lifespan due to its role in energy metabolism [74,391], which strongly relies on PPAR $\gamma$ [624-626]. Therefore, in gene network analysis, PPAR $\gamma$ was identified as one of the "longevity genes" in mouse WAT [627].

Most of the multiple traits of aging are related to PPARs and mTOR activity, oxidative stress, inflammation, and metabolism (Figure 4). Furthermore, aging-associated changes in PPAR expression and activity are reversed by CR $[229,268,628,629]$. The impact of PPARs can be particularly well observed in mutant models of longevity, the dwarf mice, a model that shows multiple similarities with CR animals [630]. These mice are characterized by a hepatic increase in PPAR $\alpha$ expression and constitutive activation of some of its target genes including genes involved in $\beta$ - and $\omega$-oxidation of FAs [220,631]. Growth hormone receptor (GHR) KO dwarf mice show similar expression patterns of PPAR $\alpha$ in the muscle and PPAR $\beta / \delta$ in the liver and skeletal muscle as WT CR mice [225]. Fittingly, mice overexpressing the bovine GH gene, which are characterized by short life span, exhibit a decrease in hepatic expression of PPAR $\alpha$ and genes involved in FA activation, $\beta$-oxidation as well as the production of ketone bodies leading to limited capacity to adjust to fasting [632]. Furthermore, overexpression of FGF21, a PPAR $\alpha$ target gene, extends lifespan in mice and blunts GH/IGF-1 signaling in the liver [633]. Therefore, the resetting of circadian rhythms by CR can lead to increased longevity and PPARs play a vital role in the rejuvenating outcomes of $\mathrm{CR}$.

\section{Conclusions}

Importantly, not only feeding schedule or feeding restriction (CR) but also nutrients entrain the circadian rhythm. A balanced combination of carbohydrate and protein induces phase advance in the liver clock, whereas the application of a single macronutrient (protein, carbohydrate, or fat) had no significant impact [634]. Similarly, the liver clock can be reset by the ingestion of a mix of glucose and amino acids, but not by either of the nutrients alone [26]. Therefore, various types of diet-related cues trigger an adjustment of circadian oscillations to adapt to the current metabolic status. In the case of CR for example, tissues need to optimize and synchronize their metabolic activity to reach beneficial homeostasis. The circadian clock controls the expression and activity of many rate-limiting enzymes and fine-tunes mechanisms of metabolic optimization and energy homeostasis. Because of its capacity to enable anticipation of daily events, it is superior in directing efficient use of energy. Resetting the circadian clocks through light, feeding, or pharmacological intervention grants metabolic health and rejuvenation underscoring the importance of the interplay between diets and biological clocks to 
promote longevity. Targeting molecular executors at the crossroad of $\mathrm{CR}$ and the circadian clock, like PPARs, may be an efficient and promising way to take advantage of the benefits of a well-calibrated circadian energy metabolism.

Author Contributions: Writing—original draft preparation and visualization K.D.; writing—review and editing, W.W. Both authors have read and agreed to the published version of the manuscript.

Funding: The writing of this review received no external funding.

Acknowledgments: The authors would like to acknowledge András Gregor for his help in correcting the manuscript. Open Access Funding by the University of Vienna.

Conflicts of Interest: The authors declare no conflict of interest.

\section{Abbreviations}

$\begin{array}{ll}\text { ACC } & \text { Acetyl-CoA carboxylase } \\ \text { AceCS } & \text { Acetyl coenzyme A synthetase } \\ \text { AICAR } & \text { 5-Aminoimidazole-4-carboxamide ribonucleoside } \\ \text { AMP } & \text { Adenosine monophosphate () } \\ \text { AMPK } & \text { Adenosine monophosphate activated protein kinase } \\ \text { AP-1 } & \text { Activating protein-1 } \\ \text { BAT } & \text { Brown adipose tissue } \\ \text { BHLGB2 } & \text { Basic helix-loop-helix domain containing class B 2 } \\ \text { BHLH } & \text { Basic helix-hoop-helix } \\ \text { BMAL1 } & \text { Brain and muscle ARNT-like protein 1 } \\ \text { CAP } & \text { Cbl-associated protein } \\ \text { CAT } & \text { Catalase } \\ \text { CKI } \varepsilon & \text { Casein kinase } \varepsilon \\ \text { CLC } & \text { Cardiotrophin-like cytokine } \\ \text { CLOCK } & \text { Circadian locomotor output cycles kaput } \\ \text { CoA } & \text { Acetyl coenzyme A } \\ \text { COX-2 } & \text { Cyclooxygenase-2 } \\ \text { cPLA } 2 & \text { Cytosolic phospholipase A2 } \\ \text { CPT } & \text { Carnitine palmitoyltransferase } \\ \text { CR } & \text { Caloric restriction } \\ \text { CREB } & \text { cAMP response element-binding protein } \\ \text { CRTC2 } & \text { cAMP response element-binding protein-regulated transcriptional coactivator-2 } \\ \text { CRY } & \text { Cryptochrome } \\ \text { CYP4A12 } & \text { Cytochrome P450 4A12 } \\ \text { DEC1 } & \text { Differentially expressed in chondrocytes 1 } \\ \text { EHHADH } & \text { 3-Hydroxyacyl CoA dehydrogenase } \\ \text { eIF2 } \alpha & \text { Eukaryotic initiation factor 2 } \alpha \\ \text { eNOS } & \text { Endothelial NO synthase } \\ \text { epSC } & \text { Epidermal stem cell } \\ \text { ERR } & \text { Estrogen-related receptor } \\ \text { FA } & \text { Fatty acid } \\ \text { FAS } & \text { Fatty acid synthase } \\ \text { FGF21 } & \text { Fibroblast growth factor 21 } \\ \text { F-L-Leu } & \text { FMOC-L-leucine } \\ \text { FMO3 } & \text { Flavin-containing monooxygenase 3 } \\ \text { FOXO } & \text { Forkhead } \\ & \\ & \end{array}$




\begin{tabular}{|c|c|}
\hline G6Pase & Glucose-6-phosphatase \\
\hline GCN2 & General control nonderepressible 2 \\
\hline GHR & Growth hormone receptor \\
\hline GLUT4 & Glucose transporter 4 \\
\hline GP & Glycogen phosphorylase \\
\hline GPx & Glutathione peroxidase \\
\hline GR & Glutathione reductase \\
\hline GRB & Granzyme B \\
\hline GSH & Glutathione \\
\hline GSSG & Oxidized glutathione \\
\hline GST & Glutathione S-transferase \\
\hline GYS & Glycogen synthase \\
\hline HAT & Histone acetyltransferase \\
\hline HDAC5 & Histone deacetylase 5 \\
\hline HFD & High-fat diet \\
\hline HMG-CoAR & 3-Hydroxy 3-methylglutaryl-CoA reductase \\
\hline HMGCS2 & 3-Hydroxy-3-methylglutaryl-CoA synthase 2 \\
\hline ICAM-1 & Intercellular-adhesion-molecule-1 \\
\hline $\mathrm{IFN} \gamma$ & Interferon $\gamma$ \\
\hline IGF-1 & Insulin-like growth factor 1 \\
\hline iNOS & Inducible nitrogen monoxide synthase \\
\hline IRS & Insulin receptor substrate \\
\hline LCAD & Long-chain acyl-coenzyme A dehydrogenase \\
\hline LKB1 & Liver kinase B1 \\
\hline LPS & Lipopolysaccharide \\
\hline MAPK & Mitogen-activated protein kinase \\
\hline MCAD & Medium-chain acyl-coa dehydrogenase \\
\hline MUP4 & Major urinary protein 4 \\
\hline mTOR & Mammalian target of rapamycin \\
\hline muSC & Skeletal muscle stem cell \\
\hline NAMPT & Nicotinamide phosphoribosyltransferase \\
\hline NAPE-PLD & N-acylphosphatidylethanolamines hydrolyzing phospholipase D \\
\hline $\mathrm{NF}-\kappa \mathrm{B}$ & Nuclear factor kappa-light-chain enhancer of activated b cells \\
\hline NMN & Nicotinamide mononucleotide \\
\hline $\mathrm{NO}$ & Nitrogen monoxide \\
\hline NRF2 & Nuclear factor erythroid 2-related factor 2 \\
\hline NSCLC & Non-small cell lung carcinoma \\
\hline OEA & Oleoylethanolamide \\
\hline PAS & Per-Arnt-Sim \\
\hline PCK1 & Phosphoenolpyruvate carboxykinase 1 \\
\hline PEPCK & Phosphoenolpyruvate-carboxykinase \\
\hline PER & Period \\
\hline PGC-1 $1 \alpha$ & Peroxisome proliferator-activated receptor $\gamma$ coactivator $1 \alpha$ \\
\hline PI3 & Phosphatidylinositol 3 \\
\hline PI3K & Phosphoinositide 3-kinase \\
\hline PK2 & Prokineticin 2 \\
\hline PPAR & Peroxisome proliferator-activated receptor \\
\hline PPRE & Peroxisome proliferator-activated receptor response element \\
\hline PRF & Perforin \\
\hline PRX & Peroxidoxin \\
\hline PTEN & Phosphatase and tensin homolog deleted on chromosome 10 \\
\hline S6K1 & Ribosomal S6 kinase 1 \\
\hline
\end{tabular}




$\begin{array}{ll}\text { SCD-1 } & \text { Stearoyl-coa desaturase-1 } \\ \text { SCN } & \text { Suprachiasmatic nucleus } \\ \text { SERPINA12 } & \text { Serpin family A member 12 } \\ \text { SIRT } & \text { Sirtuin } \\ \text { SOD-2 } & \text { Superoxide dismutase 2 } \\ \text { SREBP-1 } & \text { Sterol regulatory element-binding protein 1 } \\ \text { STAT1 } & \text { Signal transducer and activator of transcription 1 } \\ \text { RER } & \text { Respiratory exchange ratio } \\ \text { RHT } & \text { Retinohypothalamic tract } \\ \text { ROR } & \text { Retinoic acid-related orphan receptor } \\ \text { RORE } & \text { Retinoic acid-related orphan receptor response element } \\ \text { ROS } & \text { Reactive oxygen species } \\ \text { RXR } & \text { Retinoid X receptor } \\ \text { TAG } & \text { Triacylglycerol } \\ \text { TGF } \alpha & \text { Transforming growth factor } \alpha \\ \text { TIM } & \text { Timeless } \\ \text { TNF } \alpha & \text { Tumor necrosis factor } \alpha \\ \text { TOR } & \text { Target of rapamycin } \\ \text { TRF } & \text { Time-restricted feeding } \\ \text { TSC } & \text { Tuberous sclerosis protein } \\ \text { TZD } & \text { Thiazolidinediones } \\ \text { UCP2 } & \text { Uncoupling protein 2 } \\ \text { WAT } & \text { White adipose tissue } \\ \text { WT } & \text { Wild-type } \\ \text { VIP } & \text { Vasoactive intestinal polypeptide } \\ \text { VLCAD } & \text { Very long-chain acyl-coa dehydrogenase } \\ & \end{array}$

\section{References}

1. Panda, S.; Hogenesch, J.B.; Kay, S.A. Circadian rhythms from flies to human. Nature 2002, 417, $329-335$. [CrossRef] [PubMed]

2. Reppert, S.M.; Weaver, D.R. Coordination of circadian timing in mammals. Nature 2002, 418, 935-941. [CrossRef] [PubMed]

3. Refinetti, R.; Menaker, M. The circadian rhythm of body temperature. Physiol. Behav. 1992, 51, $613-637$. [CrossRef]

4. Bell-Pedersen, D.; Cassone, V.M.; Earnest, D.J.; Golden, S.S.; Hardin, P.E.; Thomas, T.L.; Zoran, M.J. Circadian rhythms from multiple oscillators: Lessons from diverse organisms. Nat. Rev. Genet. 2005, 6, 544-556. [CrossRef]

5. Schibler, U.; Ripperger, J.; Brown, S.A. Peripheral circadian oscillators in mammals: Time and food. J. Biol. Rhythms 2003, 18, 250-260. [CrossRef]

6. Panda, S.; Antoch, M.P.; Miller, B.H.; Su, A.I.; Schook, A.B.; Straume, M.; Schultz, P.G.; Kay, S.A.; Takahashi, J.S.; Hogenesch, J.B. Coordinated transcription of key pathways in the mouse by the circadian clock. Cell 2002, 109, 307-320. [CrossRef]

7. Akhtar, R.A.; Reddy, A.B.; Maywood, E.S.; Clayton, J.D.; King, V.M.; Smith, A.G.; Gant, T.W.; Hastings, M.H.; Kyriacou, C.P. Circadian cycling of the mouse liver transcriptome, as revealed by cDNA microarray, is driven by the suprachiasmatic nucleus. Curr. Biol. 2002, 12, 540-550. [CrossRef]

8. Kita, Y.; Shiozawa, M.; Jin, W.; Majewski, R.R.; Besharse, J.C.; Greene, A.S.; Jacob, H.J. Implications of circadian gene expression in kidney, liver and the effects of fasting on pharmacogenomic studies. Pharmacogenetics 2002, 12, 55-65. [CrossRef]

9. Reddy, A.B.; Karp, N.A.; Maywood, E.S.; Sage, E.A.; Deery, M.; O’Neill, J.S.; Wong, G.K.; Chesham, J.; Odell, M.; Lilley, K.S.; et al. Circadian orchestration of the hepatic proteome. Curr. Biol. 2006, 16, 1107-1115. [CrossRef] 
10. Zhang, R.; Lahens, N.F.; Ballance, H.I.; Hughes, M.E.; Hogenesch, J.B. A circadian gene expression atlas in mammals: Implications for biology and medicine. Proc. Natl. Acad. Sci. USA 2014, 111, 16219-16224. [CrossRef]

11. Dubrovsky, Y.V.; Samsa, W.E.; Kondratov, R.V. Deficiency of circadian protein CLOCK reduces lifespan and increases age-related cataract development in mice. Aging 2010, 2, 936-944. [CrossRef] [PubMed]

12. Fu, L.; Pelicano, H.; Liu, J.; Huang, P.; Lee, C. The circadian gene Period2 plays an important role in tumor suppression and DNA damage response in vivo. Cell 2002, 111, 41-50. [CrossRef]

13. Kondratov, R.V.; Kondratova, A.A.; Gorbacheva, V.Y.; Vykhovanets, O.V.; Antoch, M.P. Early aging and age-related pathologies in mice deficient in BMAL1, the core componentof the circadian clock. Genes Dev. 2006, 20, 1868-1873. [CrossRef] [PubMed]

14. Papagiannakopoulos, T.; Bauer, M.R.; Davidson, S.M.; Heimann, M.; Subbaraj, L.; Bhutkar, A.; Bartlebaugh, J.; Vander Heiden, M.G.; Jacks, T. Circadian rhythm disruption promotes lung tumorigenesis. Cell Metab. 2016, 24, 324-331. [CrossRef] [PubMed]

15. Takahashi, J.S.; Hong, H.K.; Ko, C.H.; McDearmon, E.L. The genetics of mammalian circadian order and disorder: Implications for physiology and disease. Nat. Rev. Genet. 2008, 9, 764-775. [CrossRef]

16. Davis, S.; Mirick, D.K. Circadian disruption, shift work and the risk of cancer: A summary of the evidence and studies in Seattle. Cancer Causes Control. 2006, 17, 539-545. [CrossRef]

17. Anea, C.B.; Zhang, M.; Stepp, D.W.; Simkins, G.B.; Reed, G.; Fulton, D.J.; Rudic, R.D. Vascular disease in mice with a dysfunctional circadian clock. Circulation 2009, 119, 1510-1517. [CrossRef]

18. Fonken, L.K.; Workman, J.L.; Walton, J.C.; Weil, Z.M.; Morris, J.S.; Haim, A.; Nelson, R.J. Light at night increases body mass by shifting the time of food intake. Proc. Natl. Acad. Sci. USA 2010, 107, 18664-18669. [CrossRef]

19. Salgado-Delgado, R.; Angeles-Castellanos, M.; Buijs, M.R.; Escobar, C. Internal desynchronization in a model of night-work by forced activity in rats. Neuroscience 2008, 154, 922-931. [CrossRef]

20. McHill, A.W.; Melanson, E.L.; Higgins, J.; Connick, E.; Moehlman, T.M.; Stothard, E.R.; Wright, K.P., Jr. Impact of circadian misalignment on energy metabolism during simulated nightshift work. Proc. Natl. Acad. Sci. USA 2014, 111, 17302-17307. [CrossRef]

21. Scheer, F.A.; Hilton, M.F.; Mantzoros, C.S.; Shea, S.A. Adverse metabolic and cardiovascular consequences of circadian misalignment. Proc. Natl. Acad. Sci. USA 2009, 106, 4453-4458. [CrossRef] [PubMed]

22. Gill, S.; Le, H.D.; Melkani, G.C.; Panda, S. Time-restricted feeding attenuates age-related cardiac decline in Drosophila. Science 2015, 347, 1265-1269. [CrossRef] [PubMed]

23. Patel, S.A.; Velingkaar, N.; Makwana, K.; Chaudhari, A.; Kondratov, R. Calorie restriction regulates circadian clock gene expression through BMAL1 dependent and independent mechanisms. Sci. Rep. 2016, 6, 25970. [CrossRef] [PubMed]

24. Stokkan, K.A.; Yamazaki, S.; Tei, H.; Sakaki, Y.; Menaker, M. Entrainment of the circadian clock in the liver by feeding. Science 2001, 291, 490-493. [CrossRef] [PubMed]

25. Vollmers, C.; Gill, S.; DiTacchio, L.; Pulivarthy, S.R.; Le, H.D.; Panda, S. Time of feeding and the intrinsic circadian clock drive rhythms in hepatic gene expression. Proc. Natl. Acad. Sci. USA 2009, 106, 21453-21458. [CrossRef] [PubMed]

26. Oike, H.; Nagai, K.; Fukushima, T.; Ishida, N.; Kobori, M. Feeding cues and injected nutrients induce acute expression of multiple clock genes in the mouse liver. PLoS ONE 2011, 6, e23709. [CrossRef] [PubMed]

27. Tahara, Y.; Otsuka, M.; Fuse, Y.; Hirao, A.; Shibata, S. Refeeding after fasting elicits insulin-dependent regulation of Per2 and Rev-erbalpha with shifts in the liver clock. J. Biol. Rhythms 2011, 26, 230-240. [CrossRef]

28. Hatori, M.; Vollmers, C.; Zarrinpar, A.; DiTacchio, L.; Bushong, E.A.; Gill, S.; Leblanc, M.; Chaix, A.; Joens, M.; Fitzpatrick, J.A.; et al. Time-restricted feeding without reducing caloric intake prevents metabolic diseases in mice fed a high-fat diet. Cell Metab. 2012, 15, 848-860. [CrossRef]

29. Sherman, H.; Genzer, Y.; Cohen, R.; Chapnik, N.; Madar, Z.; Froy, O. Timed high-fat diet resets circadian metabolism and prevents obesity. FASEB J. 2012, 26, 3493-3502. [CrossRef]

30. Kohsaka, A.; Laposky, A.D.; Ramsey, K.M.; Estrada, C.; Joshu, C.; Kobayashi, Y.; Turek, F.W.; Bass, J. High-fat diet disrupts behavioral and molecular circadian rhythms in mice. Cell Metab. 2007, 6, 414-421. [CrossRef] 
31. Salgado-Delgado, R.; Angeles-Castellanos, M.; Saderi, N.; Buijs, R.M.; Escobar, C. Food intake during the normal activity phase prevents obesity and circadian desynchrony in a rat model of night work. Endocrinology 2010, 151, 1019-1029. [CrossRef] [PubMed]

32. Arble, D.M.; Bass, J.; Laposky, A.D.; Vitaterna, M.H.; Turek, F.W. Circadian timing of food intake contributes to weight gain. Obesity 2009, 17, 2100-2102. [CrossRef] [PubMed]

33. Gill, S.; Panda, S. A smartphone app reveals erratic diurnal eating patterns in humans that can be modulated for health benefits. Cell Metab. 2015, 22, 789-798. [CrossRef] [PubMed]

34. Maywood, E.S.; Reddy, A.B.; Wong, G.K.; O’Neill, J.S.; O’Brien, J.A.; McMahon, D.G.; Harmar, A.J.; Okamura, H.; Hastings, M.H. Synchronization and maintenance of timekeeping in suprachiasmatic circadian clock cells by neuropeptidergic signaling. Curr. Biol. 2006, 16, 599-605. [CrossRef] [PubMed]

35. Lucas, R.J.; Freedman, M.S.; Lupi, D.; Munoz, M.; David-Gray, Z.K.; Foster, R.G. Identifying the photoreceptive inputs to the mammalian circadian system using transgenic and retinally degenerate mice. Behav. Brain Res. 2001, 125, 97-102. [CrossRef]

36. Kramer, A.; Yang, F.C.; Snodgrass, P.; Li, X.; Scammell, T.E.; Davis, F.C.; Weitz, C.J. Regulation of daily locomotor activity and sleep by hypothalamic EGF receptor signaling. Science 2001, 294, 2511-2515. [CrossRef] [PubMed]

37. Le Minh, N.; Damiola, F.; Tronche, F.; Schutz, G.; Schibler, U. Glucocorticoid hormones inhibit food-induced phase-shifting of peripheral circadian oscillators. EMBO J. 2001, 20, 7128-7136. [CrossRef] [PubMed]

38. Cheng, M.Y.; Bullock, C.M.; Li, C.; Lee, A.G.; Bermak, J.C.; Belluzzi, J.; Weaver, D.R.; Leslie, F.M.; Zhou, Q.Y. Prokineticin 2 transmits the behavioural circadian rhythm of the suprachiasmatic nucleus. Nature 2002, 417, 405-410. [CrossRef] [PubMed]

39. Kraves, S.; Weitz, C.J. A role for cardiotrophin-like cytokine in the circadian control of mammalian locomotor activity. Nat. Neurosci. 2006, 9, 212-219. [CrossRef] [PubMed]

40. Longo, V.D.; Panda, S. Fasting, circadian rhythms, and time-restricted feeding in healthy lifespan. Cell Metab. 2016, 23, 1048-1059. [CrossRef] [PubMed]

41. Vitaterna, M.H.; King, D.P.; Chang, A.M.; Kornhauser, J.M.; Lowrey, P.L.; McDonald, J.D.; Dove, W.F.; Pinto, L.H.; Turek, F.W.; Takahashi, J.S. Mutagenesis and mapping of a mouse gene, Clock, essential for circadian behavior. Science 1994, 264, 719-725. [CrossRef] [PubMed]

42. Gekakis, N.; Staknis, D.; Nguyen, H.B.; Davis, F.C.; Wilsbacher, L.D.; King, D.P.; Takahashi, J.S.; Weitz, C.J. Role of the CLOCK protein in the mammalian circadian mechanism. Science 1998, 280, 1564-1569. [CrossRef] [PubMed]

43. Kume, K.; Zylka, M.J.; Sriram, S.; Shearman, L.P.; Weaver, D.R.; Jin, X.; Maywood, E.S.; Hastings, M.H.; Reppert, S.M. mCRY1 and mCRY2 are essential components of the negative limb of the circadian clock feedback loop. Cell 1999, 98, 193-205. [CrossRef]

44. Preitner, N.; Damiola, F.; Lopez-Molina, L.; Zakany, J.; Duboule, D.; Albrecht, U.; Schibler, U. The orphan nuclear receptor REV-ERBalpha controls circadian transcription within the positive limb of the mammalian circadian oscillator. Cell 2002, 110, 251-260. [CrossRef]

45. Sato, T.K.; Panda, S.; Miraglia, L.J.; Reyes, T.M.; Rudic, R.D.; McNamara, P.; Naik, K.A.; FitzGerald, G.A.; Kay, S.A.; Hogenesch, J.B. A functional genomics strategy reveals Rora as a component of the mammalian circadian clock. Neuron 2004, 43, 527-537. [CrossRef]

46. Yin, L.; Lazar, M.A. The orphan nuclear receptor Rev-erbalpha recruits the N-CoR/histone deacetylase 3 corepressor to regulate the circadian Bmal1 gene. Mol. Endocrinol. 2005, 19, 1452-1459. [CrossRef]

47. Sato, T.K.; Yamada, R.G.; Ukai, H.; Baggs, J.E.; Miraglia, L.J.; Kobayashi, T.J.; Welsh, D.K.; Kay, S.A.; Ueda, H.R.; Hogenesch, J.B. Feedback repression is required for mammalian circadian clock function. Nat. Genet. 2006, 38, 312-319. [CrossRef]

48. Cardone, L.; Hirayama, J.; Giordano, F.; Tamaru, T.; Palvimo, J.J.; Sassone-Corsi, P. Circadian clock control by SUMOylation of BMAL1. Science 2005, 309, 1390-1394. [CrossRef]

49. Nagel, R.; Clijsters, L.; Agami, R. The miRNA-192/194 cluster regulates the Period gene family and the circadian clock. FEBS J. 2009, 276, 5447-5455. [CrossRef]

50. Stojkovic, K.; Wing, S.S.; Cermakian, N. A central role for ubiquitination within a circadian clock protein modification code. Front. Mol. Neurosci. 2014, 7, 69. [CrossRef]

51. Bellet, M.M.; Sassone-Corsi, P. Mammalian circadian clock and metabolism-The epigenetic link. J. Cell Sci. 2010, 123, 3837-3848. [CrossRef] [PubMed] 
52. Reischl, S.; Kramer, A. Kinases and phosphatases in the mammalian circadian clock. FEBS Lett. 2011, 585, 1393-1399. [CrossRef] [PubMed]

53. Speakman, J.R.; Mitchell, S.E. Caloric restriction. Mol. Aspects Med. 2011, 32, 159-221. [CrossRef] [PubMed]

54. Masoro, E.J. Overview of caloric restriction and ageing. Mech. Ageing Dev. 2005, 126, 913-922. [CrossRef] [PubMed]

55. Weindruch, R.; Walford, R.L.; Fligiel, S.; Guthrie, D. The retardation of aging in mice by dietary restriction: Longevity, cancer, immunity and lifetime energy intake. J. Nutr. 1986, 116, 641-654. [CrossRef] [PubMed]

56. Colman, R.J.; Anderson, R.M.; Johnson, S.C.; Kastman, E.K.; Kosmatka, K.J.; Beasley, T.M.; Allison, D.B.; Cruzen, C.; Simmons, H.A.; Kemnitz, J.W.; et al. Caloric restriction delays disease onset and mortality in rhesus monkeys. Science 2009, 325, 201-204. [CrossRef]

57. Anderson, R.M.; Shanmuganayagam, D.; Weindruch, R. Caloric restriction and aging: Studies in mice and monkeys. Toxicol. Pathol. 2009, 37, 47-51. [CrossRef]

58. Abalan, F.; Mayo, W.; Simon, H.; Le Moal, M. Paradoxical effect of severe dietary restriction on Long-Evans rat life span. Int. J. Vitam. Nutr. Res. 2010, 80, 386-393. [CrossRef]

59. Chung, H.Y.; Kim, H.J.; Kim, J.W.; Yu, B.P. The inflammation hypothesis of aging: Molecular modulation by calorie restriction. Ann. N. Y. Acad. Sci. 2001, 928, 327-335. [CrossRef]

60. Swindell, W.R. Genes regulated by caloric restriction have unique roles within transcriptional networks. Mech. Ageing Dev. 2008, 129, 580-592. [CrossRef]

61. Swindell, W.R. Comparative analysis of microarray data identifies common responses to caloric restriction among mouse tissues. Mech. Ageing Dev. 2008, 129, 138-153. [CrossRef] [PubMed]

62. Yan, L.; Silver, R. Neuroendocrine underpinnings of sex differences in circadian timing systems. J. Steroid. Biochem. Mol. Biol. 2016, 160, 118-126. [CrossRef] [PubMed]

63. Hadden, H.; Soldin, S.J.; Massaro, D. Circadian disruption alters mouse lung clock gene expression and lung mechanics. J. Appl. Physiol. 2012, 113, 385-392. [CrossRef] [PubMed]

64. Astafev, A.A.; Patel, S.A.; Kondratov, R.V. Calorie restriction effects on circadian rhythms in gene expression are sex dependent. Sci. Rep. 2017, 7, 9716. [CrossRef] [PubMed]

65. Mendoza, J.; Graff, C.; Dardente, H.; Pevet, P.; Challet, E. Feeding cues alter clock gene oscillations and photic responses in the suprachiasmatic nuclei of mice exposed to a light/dark cycle. J. Neurosci. 2005, 25, 1514-1522. [CrossRef] [PubMed]

66. Challet, E.; Caldelas, I.; Graff, C.; Pevet, P. Synchronization of the molecular clockwork by light- and food-related cues in mammals. Biol. Chem. 2003, 384, 711-719. [CrossRef]

67. Challet, E.; Solberg, L.C.; Turek, F.W. Entrainment in calorie-restricted mice: Conflicting zeitgebers and free-running conditions. Am. J. Physiol. 1998, 274, R1751-R1761. [CrossRef]

68. Mendoza, J.; Drevet, K.; Pevet, P.; Challet, E. Daily meal timing is not necessary for resetting the main circadian clock by calorie restriction. J. Neuroendocrinol. 2008, 20, 251-260. [CrossRef]

69. Makwana, K.; Gosai, N.; Poe, A.; Kondratov, R.V. Calorie restriction reprograms diurnal rhythms in protein translation to regulate metabolism. FASEB J. 2019, 33, 4473-4489. [CrossRef]

70. Sato, S.; Solanas, G.; Peixoto, F.O.; Bee, L.; Symeonidi, A.; Schmidt, M.S.; Brenner, C.; Masri, S.; Benitah, S.A.; Sassone-Corsi, P. Circadian reprogramming in the liver identifies metabolic pathways of aging. Cell 2017, 170, 664-677.e611. [CrossRef]

71. Patel, S.A.; Chaudhari, A.; Gupta, R.; Velingkaar, N.; Kondratov, R.V. Circadian clocks govern calorie restriction-mediated life span extension through BMAL1- and IGF-1-dependent mechanisms. FASEB J. 2016, 30, 1634-1642. [CrossRef] [PubMed]

72. Zwighaft, Z.; Aviram, R.; Shalev, M.; Rousso-Noori, L.; Kraut-Cohen, J.; Golik, M.; Brandis, A.; Reinke, H.; Aharoni, A.; Kahana, C.; et al. Circadian clock control by polyamine levels through a mechanism that declines with age. Cell Metab. 2015, 22, 874-885. [CrossRef] [PubMed]

73. Duszka, K.; Gregor, A.; Guillou, H.; Konig, J.; Wahli, W. Peroxisome proliferator-activated receptors and caloric restriction-common pathways affecting metabolism, health, and longevity. Cells 2020, 9, 1708. [CrossRef] [PubMed]

74. Bluher, M.; Kahn, B.B.; Kahn, C.R. Extended longevity in mice lacking the insulin receptor in adipose tissue. Science 2003, 299, 572-574. [CrossRef] [PubMed]

75. Tatar, M.; Bartke, A.; Antebi, A. The endocrine regulation of aging by insulin-like signals. Science 2003, 299, 1346-1351. [CrossRef] 
76. Kenyon, C.; Chang, J.; Gensch, E.; Rudner, A.; Tabtiang, R. A C. elegans mutant that lives twice as long as wild type. Nature 1993, 366, 461-464. [CrossRef]

77. Taguchi, A.; Wartschow, L.M.; White, M.F. Brain IRS2 signaling coordinates life span and nutrient homeostasis. Science 2007, 317, 369-372. [CrossRef]

78. Selman, C.; Lingard, S.; Choudhury, A.I.; Batterham, R.L.; Claret, M.; Clements, M.; Ramadani, F.; Okkenhaug, K.; Schuster, E.; Blanc, E.; et al. Evidence for lifespan extension and delayed age-related biomarkers in insulin receptor substrate 1 null mice. FASEB J. 2008, 22, 807-818. [CrossRef]

79. Weindruch, R. The retardation of aging by caloric restriction: Studies in rodents and primates. Toxicol. Pathol. 1996, 24, 742-745. [CrossRef]

80. Kim, D.H.; Park, M.H.; Lee, E.K.; Choi, Y.J.; Chung, K.W.; Moon, K.M.; Kim, M.J.; An, H.J.; Park, J.W.; Kim, N.D.; et al. The roles of FoxOs in modulation of aging by calorie restriction. Biogerontology 2015, 16, 1-14. [CrossRef]

81. Oh, W.J.; Jacinto, E. mTOR complex 2 signaling and functions. Cell Cycle 2011, 10, 2305-2316. [CrossRef] [PubMed]

82. Rowland, A.F.; Fazakerley, D.J.; James, D.E. Mapping insulin/GLUT4 circuitry. Traffic 2011, 12, $672-681$. [CrossRef] [PubMed]

83. Siddle, K. Signalling by insulin and IGF receptors: Supporting acts and new players. J. Mol. Endocrinol. 2011, 47, R1-R10. [CrossRef] [PubMed]

84. Piscitello, D.; Varshney, D.; Lilla, S.; Vizioli, M.G.; Reid, C.; Gorbunova, V.; Seluanov, A.; Gillespie, D.A.; Adams, P.D. AKT overactivation can suppress DNA repair via p70S6 kinase-dependent downregulation of MRE11. Oncogene 2018, 37, 427-438. [CrossRef] [PubMed]

85. Jia, Y.; Song, W.; Zhang, F.; Yan, J.; Yang, Q. Akt1 inhibits homologous recombination in Brca1-deficient cells by blocking the Chk1-Rad51 pathway. Oncogene 2013, 32, 1943-1949. [CrossRef] [PubMed]

86. Liu, P.; Gan, W.; Guo, C.; Xie, A.; Gao, D.; Guo, J.; Zhang, J.; Willis, N.; Su, A.; Asara, J.M.; et al. Akt-mediated phosphorylation of XLF impairs non-homologous end-joining DNA repair. Mol. Cell 2015, 57, 648-661. [CrossRef] [PubMed]

87. Zhang, E.E.; Liu, A.C.; Hirota, T.; Miraglia, L.J.; Welch, G.; Pongsawakul, P.Y.; Liu, X.; Atwood, A.; Huss, J.W., 3rd; Janes, J.; et al. A genome-wide RNAi screen for modifiers of the circadian clock in human cells. Cell 2009, 139, 199-210. [CrossRef] [PubMed]

88. Yamajuku, D.; Inagaki, T.; Haruma, T.; Okubo, S.; Kataoka, Y.; Kobayashi, S.; Ikegami, K.; Laurent, T.; Kojima, T.; Noutomi, K.; et al. Real-time monitoring in three-dimensional hepatocytes reveals that insulin acts as a synchronizer for liver clock. Sci. Rep. 2012, 2, 439. [CrossRef]

89. Lamia, K.A.; Sachdeva, U.M.; DiTacchio, L.; Williams, E.C.; Alvarez, J.G.; Egan, D.F.; Vasquez, D.S.; Juguilon, H.; Panda, S.; Shaw, R.J.; et al. AMPK regulates the circadian clock by cryptochrome phosphorylation and degradation. Science 2009, 326, 437-440. [CrossRef]

90. Iwanaga, H.; Yano, M.; Miki, H.; Okada, K.; Azama, T.; Takiguchi, S.; Fujiwara, Y.; Yasuda, T.; Nakayama, M.; Kobayashi, M.; et al. Per2 gene expressions in the suprachiasmatic nucleus and liver differentially respond to nutrition factors in rats. JPEN J. Parenter. Enteral. Nutr. 2005, 29, 157-161. [CrossRef]

91. Challet, E.; Losee-Olson, S.; Turek, F.W. Reduced glucose availability attenuates circadian responses to light in mice. Am. J. Physiol. 1999, 276, R1063-R1070. [CrossRef] [PubMed]

92. Hirota, T.; Okano, T.; Kokame, K.; Shirotani-Ikejima, H.; Miyata, T.; Fukada, Y. Glucose down-regulates Per1 and Per2 mRNA levels and induces circadian gene expression in cultured Rat-1 fibroblasts. J. Biol. Chem. 2002, 277, 44244-44251. [CrossRef] [PubMed]

93. Marcheva, B.; Ramsey, K.M.; Buhr, E.D.; Kobayashi, Y.; Su, H.; Ko, C.H.; Ivanova, G.; Omura, C.; Mo, S.; Vitaterna, M.H.; et al. Disruption of the clock components CLOCK and BMAL1 leads to hypoinsulinaemia and diabetes. Nature 2010, 466, 627-631. [CrossRef] [PubMed]

94. Vieira, E.; Marroqui, L.; Figueroa, A.L.; Merino, B.; Fernandez-Ruiz, R.; Nadal, A.; Burris, T.P.; Gomis, R.; Quesada, I. Involvement of the clock gene Rev-erb alpha in the regulation of glucagon secretion in pancreatic alpha-cells. PLOS ONE 2013, 8, e69939. [CrossRef] [PubMed]

95. Sadacca, L.A.; Lamia, K.A.; deLemos, A.S.; Blum, B.; Weitz, C.J. An intrinsic circadian clock of the pancreas is required for normal insulin release and glucose homeostasis in mice. Diabetologia 2011, 54, 120-124. [CrossRef] [PubMed] 
96. Vieira, E.; Merino, B.; Quesada, I. Role of the clock gene Rev-erbalpha in metabolism and in the endocrine pancreas. Diabetes Obes. Metab. 2015, 17 (Suppl. S1), 106-114. [CrossRef] [PubMed]

97. Muhlbauer, E.; Wolgast, S.; Finckh, U.; Peschke, D.; Peschke, E. Indication of circadian oscillations in the rat pancreas. FEBS Lett. 2004, 564, 91-96. [CrossRef]

98. Rudic, R.D.; McNamara, P.; Curtis, A.M.; Boston, R.C.; Panda, S.; Hogenesch, J.B.; Fitzgerald, G.A. BMAL1 and CLOCK, two essential components of the circadian clock, are involved in glucose homeostasis. PLoS Biol. 2004, 2, e377. [CrossRef]

99. Barclay, J.L.; Shostak, A.; Leliavski, A.; Tsang, A.H.; Johren, O.; Muller-Fielitz, H.; Landgraf, D.; Naujokat, N.; van der Horst, G.T.; Oster, H. High-fat diet-induced hyperinsulinemia and tissue-specific insulin resistance in Cry-deficient mice. Am. J. Physiol. Endocrinol. Metab. 2013, 304, E1053-E1063. [CrossRef]

100. Zhao, Y.; Zhang, Y.; Zhou, M.; Wang, S.; Hua, Z.; Zhang, J. Loss of mPer2 increases plasma insulin levels by enhanced glucose-stimulated insulin secretion and impaired insulin clearance in mice. FEBS Lett. 2012, 586, 1306-1311. [CrossRef]

101. Delezie, J.; Dumont, S.; Dardente, H.; Oudart, H.; Grechez-Cassiau, A.; Klosen, P.; Teboul, M.; Delaunay, F.; Pevet, P.; Challet, E. The nuclear receptor REV-ERBalpha is required for the daily balance of carbohydrate and lipid metabolism. FASEB J. 2012, 26, 3321-3335. [CrossRef] [PubMed]

102. Kalsbeek, A.; la Fleur, S.; Fliers, E. Circadian control of glucose metabolism. Mol. Metab. 2014, 3, $372-383$. [CrossRef] [PubMed]

103. Doi, R.; Oishi, K.; Ishida, N. CLOCK regulates circadian rhythms of hepatic glycogen synthesis through transcriptional activation of Gys2. J. Biol. Chem. 2010, 285, 22114-22121. [CrossRef] [PubMed]

104. Matsuoka, H.; Shima, A.; Kuramoto, D.; Kikumoto, D.; Matsui, T.; Michihara, A. Phosphoenolpyruvate carboxykinase, a key enzyme that controls blood glucose, is a target of retinoic acid receptor-related orphan receptor alpha. PLoS ONE 2015, 10, e0137955. [CrossRef] [PubMed]

105. Kadiri, S.; Monnier, C.; Ganbold, M.; Ledent, T.; Capeau, J.; Antoine, B. The nuclear retinoid-related orphan receptor-alpha regulates adipose tissue glyceroneogenesis in addition to hepatic gluconeogenesis. Am. J. Physiol Endocrinol. Metab. 2015, 309, E105-E114. [CrossRef]

106. Kojetin, D.; Wang, Y.; Kamenecka, T.M.; Burris, T.P. Identification of SR8278, a synthetic antagonist of the nuclear heme receptor REV-ERB. ACS Chem. Biol. 2011, 6, 131-134. [CrossRef] [PubMed]

107. Yin, L.; Wu, N.; Curtin, J.C.; Qatanani, M.; Szwergold, N.R.; Reid, R.A.; Waitt, G.M.; Parks, D.J.; Pearce, K.H.; Wisely, G.B.; et al. Rev-erbalpha, a heme sensor that coordinates metabolic and circadian pathways. Science 2007, 318, 1786-1789. [CrossRef]

108. Zhang, E.E.; Liu, Y.; Dentin, R.; Pongsawakul, P.Y.; Liu, A.C.; Hirota, T.; Nusinow, D.A.; Sun, X.; Landais, S.; Kodama, Y.; et al. Cryptochrome mediates circadian regulation of cAMP signaling and hepatic gluconeogenesis. Nat. Med. 2010, 16, 1152-1156. [CrossRef]

109. Lamia, K.A.; Papp, S.J.; Yu, R.T.; Barish, G.D.; Uhlenhaut, N.H.; Jonker, J.W.; Downes, M.; Evans, R.M. Cryptochromes mediate rhythmic repression of the glucocorticoid receptor. Nature 2011, 480, 552-556. [CrossRef]

110. Zani, F.; Breasson, L.; Becattini, B.; Vukolic, A.; Montani, J.P.; Albrecht, U.; Provenzani, A.; Ripperger, J.A.; Solinas, G. PER2 promotes glucose storage to liver glycogen during feeding and acute fasting by inducing Gys2 PTG and G L expression. Mol. Metab. 2013, 2, 292-305. [CrossRef]

111. Bhaskar, P.T.; Hay, N. The two TORCs and Akt. Dev. Cell 2007, 12, 487-502. [CrossRef] [PubMed]

112. Wullschleger, S.; Loewith, R.; Hall, M.N. TOR signaling in growth and metabolism. Cell 2006, 124, 471-484. [CrossRef] [PubMed]

113. Loewith, R.; Jacinto, E.; Wullschleger, S.; Lorberg, A.; Crespo, J.L.; Bonenfant, D.; Oppliger, W.; Jenoe, P.; Hall, M.N. Two TOR complexes, only one of which is rapamycin sensitive, have distinct roles in cell growth control. Mol. Cell 2002, 10, 457-468. [CrossRef]

114. Jacinto, E.; Loewith, R.; Schmidt, A.; Lin, S.; Ruegg, M.A.; Hall, A.; Hall, M.N. Mammalian TOR complex 2 controls the actin cytoskeleton and is rapamycin insensitive. Nat. Cell Biol. 2004, 6, 1122-1128. [CrossRef] [PubMed]

115. Corradetti, M.N.; Guan, K.L. Upstream of the mammalian target of rapamycin: Do all roads pass through mTOR? Oncogene 2006, 25, 6347-6360. [CrossRef]

116. Hay, N.; Sonenberg, N. Upstream and downstream of mTOR. Genes Dev. 2004, 18, 1926-1945. [CrossRef] 
117. Arsham, A.M.; Neufeld, T.P. Thinking globally and acting locally with TOR. Curr. Opin. Cell Biol. 2006, 18, 589-597. [CrossRef]

118. Duvel, K.; Yecies, J.L.; Menon, S.; Raman, P.; Lipovsky, A.I.; Souza, A.L.; Triantafellow, E.; Ma, Q.; Gorski, R.; Cleaver, S.; et al. Activation of a metabolic gene regulatory network downstream of mTOR complex 1. Mol. Cell 2010, 39, 171-183. [CrossRef]

119. Hudson, C.C.; Liu, M.; Chiang, G.G.; Otterness, D.M.; Loomis, D.C.; Kaper, F.; Giaccia, A.J.; Abraham, R.T. Regulation of hypoxia-inducible factor 1alpha expression and function by the mammalian target of rapamycin. Mol. Cell Biol. 2002, 22, 7004-7014. [CrossRef]

120. Kim, J.E.; Chen, J. regulation of peroxisome proliferator-activated receptor-gamma activity by mammalian target of rapamycin and amino acids in adipogenesis. Diabetes 2004, 53, 2748-2756. [CrossRef]

121. Zhang, H.H.; Huang, J.; Duvel, K.; Boback, B.; Wu, S.; Squillace, R.M.; Wu, C.L.; Manning, B.D. Insulin stimulates adipogenesis through the Akt-TSC2-mTORC1 pathway. PLoS ONE 2009, 4, e6189. [CrossRef] [PubMed]

122. Porstmann, T.; Santos, C.R.; Griffiths, B.; Cully, M.; Wu, M.; Leevers, S.; Griffiths, J.R.; Chung, Y.L.; Schulze, A. SREBP activity is regulated by mTORC1 and contributes to Akt-dependent cell growth. Cell Metab. 2008, 8, 224-236. [CrossRef] [PubMed]

123. Wang, B.T.; Ducker, G.S.; Barczak, A.J.; Barbeau, R.; Erle, D.J.; Shokat, K.M. The mammalian target of rapamycin regulates cholesterol biosynthetic gene expression and exhibits a rapamycin-resistant transcriptional profile. Proc. Natl. Acad. Sci. USA 2011, 108, 15201-15206. [CrossRef] [PubMed]

124. Kim, J.; Guan, K.L. mTOR as a central hub of nutrient signalling and cell growth. Nat. Cell Biol. 2019, 21, 63-71. [CrossRef] [PubMed]

125. Zhao, J.; Zhai, B.; Gygi, S.P.; Goldberg, A.L. mTOR inhibition activates overall protein degradation by the ubiquitin proteasome system as well as by autophagy. Proc. Natl. Acad. Sci. USA 2015, 112, 15790-15797. [CrossRef] [PubMed]

126. Cao, R.; Lee, B.; Cho, H.Y.; Saklayen, S.; Obrietan, K. Photic regulation of the mTOR signaling pathway in the suprachiasmatic circadian clock. Mol. Cell Neurosci. 2008, 38, 312-324. [CrossRef] [PubMed]

127. Cao, R.; Anderson, F.E.; Jung, Y.J.; Dziema, H.; Obrietan, K. Circadian regulation of mammalian target of rapamycin signaling in the mouse suprachiasmatic nucleus. Neuroscience 2011, 181, 79-88. [CrossRef]

128. Cornu, M.; Oppliger, W.; Albert, V.; Robitaille, A.M.; Trapani, F.; Quagliata, L.; Fuhrer, T.; Sauer, U.; Terracciano, L.; Hall, M.N. Hepatic mTORC1 controls locomotor activity, body temperature, and lipid metabolism through FGF21. Proc. Natl. Acad. Sci. USA 2014, 111, 11592-11599. [CrossRef]

129. Jouffe, C.; Cretenet, G.; Symul, L.; Martin, E.; Atger, F.; Naef, F.; Gachon, F. The circadian clock coordinates ribosome biogenesis. PLoS Biol. 2013, 11, e1001455. [CrossRef]

130. Khapre, R.V.; Kondratova, A.A.; Patel, S.; Dubrovsky, Y.; Wrobel, M.; Antoch, M.P.; Kondratov, R.V. BMAL1-dependent regulation of the mTOR signaling pathway delays aging. Aging 2014, 6, 48-57. [CrossRef]

131. Lipton, J.O.; Yuan, E.D.; Boyle, L.M.; Ebrahimi-Fakhari, D.; Kwiatkowski, E.; Nathan, A.; Guttler, T.; Davis, F.; Asara, J.M.; Sahin, M. The circadian protein BMAL1 regulates translation in response to S6K1-mediated phosphorylation. Cell 2015, 161, 1138-1151. [CrossRef] [PubMed]

132. Huang, C.C.; Ko, M.L.; Ko, G.Y. A new functional role for mechanistic/mammalian target of rapamycin complex 1 (mTORC1) in the circadian regulation of L-type voltage-gated calcium channels in avian cone photoreceptors. PLoS ONE 2013, 8, e73315. [CrossRef] [PubMed]

133. Dragert, K.; Bhattacharya, I.; Hall, M.N.; Humar, R.; Battegay, E.; Haas, E. Basal mTORC2 activity and expression of its components display diurnal variation in mouse perivascular adipose tissue. Biochem. Biophys. Res. Commun. 2016, 473, 317-322. [CrossRef] [PubMed]

134. Chang, S.W.; Yoshihara, T.; Machida, S.; Naito, H. Circadian rhythm of intracellular protein synthesis signaling in rat cardiac and skeletal muscles. Biochem. Biophys. Rep. 2017, 9, 153-158. [CrossRef] [PubMed]

135. Saraf, A.; Luo, J.; Morris, D.R.; Storm, D.R. Phosphorylation of eukaryotic translation initiation factor $4 \mathrm{E}$ and eukaryotic translation initiation factor 4E-binding protein (4EBP) and their upstream signaling components undergo diurnal oscillation in the mouse hippocampus: Implications for memory persistence. J. Biol. Chem. 2014, 289, 20129-20138. [CrossRef] [PubMed]

136. Albert, V.; Cornu, M.; Hall, M.N. mTORC1 signaling in Agrp neurons mediates circadian expression of Agrp and NPY but is dispensable for regulation of feeding behavior. Biochem. Biophys. Res. Commun. 2015, 464, 480-486. [CrossRef] [PubMed] 
137. Khapre, R.V.; Patel, S.A.; Kondratova, A.A.; Chaudhary, A.; Velingkaar, N.; Antoch, M.P.; Kondratov, R.V. Metabolic clock generates nutrient anticipation rhythms in mTOR signaling. Aging 2014, 6, 675-689. [CrossRef]

138. Zheng, X.; Sehgal, A. AKT and TOR signaling set the pace of the circadian pacemaker. Curr. Biol. 2010, 20, 1203-1208. [CrossRef]

139. Kijak, E.; Pyza, E. TOR signaling pathway and autophagy are involved in the regulation of circadian rhythms in behavior and plasticity of L2 interneurons in the brain of Drosophila melanogaster. PLoS ONE 2017, 12, e0171848. [CrossRef]

140. Cao, R.; Robinson, B.; Xu, H.; Gkogkas, C.; Khoutorsky, A.; Alain, T.; Yanagiya, A.; Nevarko, T.; Liu, A.C.; Amir, S.; et al. Translational control of entrainment and synchrony of the suprachiasmatic circadian clock by mTOR/4E-BP1 signaling. Neuron 2013, 79, 712-724. [CrossRef]

141. Cao, R.; Li, A.; Cho, H.Y.; Lee, B.; Obrietan, K. Mammalian target of rapamycin signaling modulates photic entrainment of the suprachiasmatic circadian clock. J. Neurosci. 2010, 30, 6302-6314. [CrossRef] [PubMed]

142. Ramanathan, C.; Kathale, N.D.; Liu, D.; Lee, C.; Freeman, D.A.; Hogenesch, J.B.; Cao, R.; Liu, A.C. mTOR signaling regulates central and peripheral circadian clock function. PLoS Genet. 2018, 14, e1007369. [CrossRef] [PubMed]

143. Feeney, K.A.; Hansen, L.L.; Putker, M.; Olivares-Yanez, C.; Day, J.; Eades, L.J.; Larrondo, L.F.; Hoyle, N.P.; O'Neill, J.S.; van Ooijen, G. Daily magnesium fluxes regulate cellular timekeeping and energy balance. Nature 2016, 532, 375-379. [CrossRef] [PubMed]

144. Winder, W.W.; Hardie, D.G. AMP-activated protein kinase, a metabolic master switch: Possible roles in type 2 diabetes. Am. J. Physiol. 1999, 277, E1-E10. [CrossRef] [PubMed]

145. Koo, S.H.; Flechner, L.; Qi, L.; Zhang, X.; Screaton, R.A.; Jeffries, S.; Hedrick, S.; Xu, W.; Boussouar, F.; Brindle, P.; et al. The CREB coactivator TORC2 is a key regulator of fasting glucose metabolism. Nature 2005, 437, 1109-1111. [CrossRef] [PubMed]

146. Chen, S.; Murphy, J.; Toth, R.; Campbell, D.G.; Morrice, N.A.; Mackintosh, C. Complementary regulation of TBC1D1 and AS160 by growth factors, insulin and AMPK activators. Biochem. J. 2008, 409, 449-459. [CrossRef] [PubMed]

147. Geraghty, K.M.; Chen, S.; Harthill, J.E.; Ibrahim, A.F.; Toth, R.; Morrice, N.A.; Vandermoere, F.; Moorhead, G.B.; Hardie, D.G.; MacKintosh, C. Regulation of multisite phosphorylation and 14-3-3 binding of AS160 in response to IGF-1, EGF, PMA and AICAR. Biochem. J. 2007, 407, 231-241. [CrossRef]

148. Jager, S.; Handschin, C.; St-Pierre, J.; Spiegelman, B.M. AMP-activated protein kinase (AMPK) action in skeletal muscle via direct phosphorylation of PGC-1alpha. Proc. Natl. Acad. Sci. USA 2007, 104, 12017-12022. [CrossRef]

149. McGee, S.L.; van Denderen, B.J.; Howlett, K.F.; Mollica, J.; Schertzer, J.D.; Kemp, B.E.; Hargreaves, M. AMP-activated protein kinase regulates GLUT4 transcription by phosphorylating histone deacetylase 5. Diabetes 2008, 57, 860-867. [CrossRef]

150. Davies, S.P.; Sim, A.T.; Hardie, D.G. Location and function of three sites phosphorylated on rat acetyl-CoA carboxylase by the AMP-activated protein kinase. Eur. J. Biochem. 1990, 187, 183-190. [CrossRef]

151. Davies, S.P.; Carling, D.; Munday, M.R.; Hardie, D.G. Diurnal rhythm of phosphorylation of rat liver acetyl-CoA carboxylase by the AMP-activated protein kinase, demonstrated using freeze-clamping. Effects of high fat diets. Eur. J. Biochem. 1992, 203, 615-623. [CrossRef] [PubMed]

152. Li, Y.; Xu, S.; Mihaylova, M.M.; Zheng, B.; Hou, X.; Jiang, B.; Park, O.; Luo, Z.; Lefai, E.; Shyy, J.Y.; et al. AMPK phosphorylates and inhibits SREBP activity to attenuate hepatic steatosis and atherosclerosis in diet-induced insulin-resistant mice. Cell Metab. 2011, 13, 376-388. [CrossRef] [PubMed]

153. Muoio, D.M.; Seefeld, K.; Witters, L.A.; Coleman, R.A. AMP-activated kinase reciprocally regulates triacylglycerol synthesis and fatty acid oxidation in liver and muscle: Evidence that sn-glycerol-3-phosphate acyltransferase is a novel target. Biochem. J. 1999, 338, 783-791. [CrossRef] [PubMed]

154. Clarke, P.R.; Hardie, D.G. Regulation of HMG-CoA reductase: Identification of the site phosphorylated by the AMP-activated protein kinase in vitro and in intact rat liver. EMBO J. 1990, 9, 2439-2446. [CrossRef] [PubMed]

155. Hoppe, S.; Bierhoff, H.; Cado, I.; Weber, A.; Tiebe, M.; Grummt, I.; Voit, R. AMP-activated protein kinase adapts rRNA synthesis to cellular energy supply. Proc. Natl. Acad. Sci. USA 2009, 106, 17781-17786. [CrossRef] 
156. Marsin, A.S.; Bouzin, C.; Bertrand, L.; Hue, L. The stimulation of glycolysis by hypoxia in activated monocytes is mediated by AMP-activated protein kinase and inducible 6-phosphofructo-2-kinase. J. Biol. Chem. 2002, 277, 30778-30783. [CrossRef]

157. Jorgensen, S.B.; Nielsen, J.N.; Birk, J.B.; Olsen, G.S.; Viollet, B.; Andreelli, F.; Schjerling, P.; Vaulont, S.; Hardie, D.G.; Hansen, B.F.; et al. The alpha2-5'AMP-activated protein kinase is a site 2 glycogen synthase kinase in skeletal muscle and is responsive to glucose loading. Diabetes 2004, 53, 3074-3081. [CrossRef]

158. Hardie, D.G.; Ross, F.A.; Hawley, S.A. AMPK: A nutrient and energy sensor that maintains energy homeostasis. Nat. Rev. Mol. Cell Biol. 2012, 13, 251-262. [CrossRef]

159. Leclerc, I.; Lenzner, C.; Gourdon, L.; Vaulont, S.; Kahn, A.; Viollet, B. Hepatocyte nuclear factor-4alpha involved in type 1 maturity-onset diabetes of the young is a novel target of AMP-activated protein kinase. Diabetes 2001, 50, 1515-1521. [CrossRef]

160. Lee, J.M.; Seo, W.Y.; Song, K.H.; Chanda, D.; Kim, Y.D.; Kim, D.K.; Lee, M.W.; Ryu, D.; Kim, Y.H.; Noh, J.R.; et al. AMPK-dependent repression of hepatic gluconeogenesis via disruption of CREB.CRTC2 complex by orphan nuclear receptor small heterodimer partner. J. Biol. Chem. 2010, 285, 32182-32191. [CrossRef]

161. Dufer, M.; Noack, K.; Krippeit-Drews, P.; Drews, G. Activation of the AMP-activated protein kinase enhances glucose-stimulated insulin secretion in mouse beta-cells. Islets 2010, 2, 156-163. [CrossRef] [PubMed]

162. Chavez, J.A.; Roach, W.G.; Keller, S.R.; Lane, W.S.; Lienhard, G.E. Inhibition of GLUT4 translocation by Tbc1d1, a Rab GTPase-activating protein abundant in skeletal muscle, is partially relieved by AMP-activated protein kinase activation. J. Biol. Chem. 2008, 283, 9187-9195. [CrossRef] [PubMed]

163. Steinberg, G.R.; Kemp, B.E. AMPK in health and disease. Physiol. Rev. 2009, 89, 1025-1078. [CrossRef] [PubMed]

164. Suzuki, A.; Okamoto, S.; Lee, S.; Saito, K.; Shiuchi, T.; Minokoshi, Y. Leptin stimulates fatty acid oxidation and peroxisome proliferator-activated receptor alpha gene expression in mouse $\mathrm{C} 2 \mathrm{C} 12$ myoblasts by changing the subcellular localization of the alpha2 form of AMP-activated protein kinase. Mol. Cell Biol. 2007, 27, 4317-4327. [CrossRef] [PubMed]

165. Um, J.H.; Pendergast, J.S.; Springer, D.A.; Foretz, M.; Viollet, B.; Brown, A.; Kim, M.K.; Yamazaki, S.; Chung, J.H. AMPK regulates circadian rhythms in a tissue- and isoform-specific manner. PLoS ONE 2011, 6, e18450. [CrossRef] [PubMed]

166. Vieira, E.; Nilsson, E.C.; Nerstedt, A.; Ormestad, M.; Long, Y.C.; Garcia-Roves, P.M.; Zierath, J.R.; Mahlapuu, M. Relationship between AMPK and the transcriptional balance of clock-related genes in skeletal muscle. Am. J. Physiol. Endocrinol. Metab. 2008, 295, E1032-E1037. [CrossRef]

167. Um, J.H.; Yang, S.; Yamazaki, S.; Kang, H.; Viollet, B.; Foretz, M.; Chung, J.H. Activation of 5'-AMP-activated kinase with diabetes drug metformin induces casein kinase Iepsilon (CKIepsilon)-dependent degradation of clock protein mPer2. J. Biol. Chem. 2007, 282, 20794-20798. [CrossRef]

168. Grimaldi, B.; Sassone-Corsi, P. Circadian rhythms: Metabolic clockwork. Nature 2007, 447, 386-387. [CrossRef]

169. Liu, C.; Li, S.; Liu, T.; Borjigin, J.; Lin, J.D. Transcriptional coactivator PGC-1alpha integrates the mammalian clock and energy metabolism. Nature 2007, 447, 477-481. [CrossRef]

170. Minokoshi, Y.; Alquier, T.; Furukawa, N.; Kim, Y.B.; Lee, A.; Xue, B.; Mu, J.; Foufelle, F.; Ferre, P.; Birnbaum, M.J.; et al. AMP-kinase regulates food intake by responding to hormonal and nutrient signals in the hypothalamus. Nature 2004, 428, 569-574. [CrossRef]

171. Andersson, U.; Filipsson, K.; Abbott, C.R.; Woods, A.; Smith, K.; Bloom, S.R.; Carling, D.; Small, C.J. AMP-activated protein kinase plays a role in the control of food intake. J. Biol. Chem. 2004, 279, 12005-12008. [CrossRef] [PubMed]

172. Liou, G.G.; Tanny, J.C.; Kruger, R.G.; Walz, T.; Moazed, D. Assembly of the SIR complex and its regulation by O-acetyl-ADP-ribose, a product of NAD-dependent histone deacetylation. Cell 2005, 121, 515-527. [CrossRef] [PubMed]

173. Vaquero, A.; Scher, M.; Lee, D.; Erdjument-Bromage, H.; Tempst, P.; Reinberg, D. Human SirT1 interacts with histone $\mathrm{H} 1$ and promotes formation of facultative heterochromatin. Mol. Cell 2004, 16, 93-105. [CrossRef] [PubMed]

174. Dang, W. The controversial world of sirtuins. Drug. Discov. Today Technol. 2014, 12, e9-e17. [CrossRef] [PubMed]

175. Houtkooper, R.H.; Pirinen, E.; Auwerx, J. Sirtuins as regulators of metabolism and healthspan. Nat. Rev. Mol. Cell Biol. 2012, 13, 225-238. [CrossRef] [PubMed] 
176. Shimazu, T.; Hirschey, M.D.; Hua, L.; Dittenhafer-Reed, K.E.; Schwer, B.; Lombard, D.B.; Li, Y.; Bunkenborg, J.; Alt, F.W.; Denu, J.M.; et al. SIRT3 deacetylates mitochondrial 3-hydroxy-3-methylglutaryl CoA synthase 2 and regulates ketone body production. Cell Metab. 2010, 12, 654-661. [CrossRef]

177. Hirschey, M.D.; Shimazu, T.; Goetzman, E.; Jing, E.; Schwer, B.; Lombard, D.B.; Grueter, C.A.; Harris, C.; Biddinger, S.; Ilkayeva, O.R.; et al. SIRT3 regulates mitochondrial fatty-acid oxidation by reversible enzyme deacetylation. Nature 2010, 464, 121-125. [CrossRef]

178. Qiu, X.; Brown, K.; Hirschey, M.D.; Verdin, E.; Chen, D. Calorie restriction reduces oxidative stress by SIRT3-mediated SOD2 activation. Cell Metab. 2010, 12, 662-667. [CrossRef]

179. Preyat, N.; Leo, O. Sirtuin deacylases: A molecular link between metabolism and immunity. J. Leukoc. Biol. 2013, 93, 669-680. [CrossRef]

180. Satoh, A.; Brace, C.S.; Ben-Josef, G.; West, T.; Wozniak, D.F.; Holtzman, D.M.; Herzog, E.D.; Imai, S. SIRT1 promotes the central adaptive response to diet restriction through activation of the dorsomedial and lateral nuclei of the hypothalamus. J. Neurosci. 2010, 30, 10220-10232. [CrossRef]

181. Kaeberlein, M.; McVey, M.; Guarente, L. The SIR2/3/4 complex and SIR2 alone promote longevity in Saccharomyces cerevisiae by two different mechanisms. Genes Dev. 1999, 13, 2570-2580. [CrossRef] [PubMed]

182. Whitaker, R.; Faulkner, S.; Miyokawa, R.; Burhenn, L.; Henriksen, M.; Wood, J.G.; Helfand, S.L. Increased expression of Drosophila Sir2 extends life span in a dose-dependent manner. Aging 2013, 5, 682-691. [CrossRef] [PubMed]

183. Lin, S.J.; Defossez, P.A.; Guarente, L. Requirement of NAD and SIR2 for life-span extension by calorie restriction in Saccharomyces cerevisiae. Science 2000, 289, 2126-2128. [CrossRef] [PubMed]

184. Rogina, B.; Helfand, S.L. Sir2 mediates longevity in the fly through a pathway related to calorie restriction. Proc. Natl. Acad. Sci. USA 2004, 101, 15998-16003. [CrossRef] [PubMed]

185. Tissenbaum, H.A.; Guarente, L. Increased dosage of a sir-2 gene extends lifespan in Caenorhabditis elegans. Nature 2001, 410, 227-230. [CrossRef] [PubMed]

186. Oberdoerffer, P.; Michan, S.; McVay, M.; Mostoslavsky, R.; Vann, J.; Park, S.K.; Hartlerode, A.; Stegmuller, J.; Hafner, A.; Loerch, P.; et al. SIRT1 redistribution on chromatin promotes genomic stability but alters gene expression during aging. Cell 2008, 135, 907-918. [CrossRef] [PubMed]

187. Rodgers, J.T.; Lerin, C.; Haas, W.; Gygi, S.P.; Spiegelman, B.M.; Puigserver, P. Nutrient control of glucose homeostasis through a complex of PGC-1alpha and SIRT1. Nature 2005, 434, 113-118. [CrossRef]

188. Nemoto, S.; Fergusson, M.M.; Finkel, T. SIRT1 functionally interacts with the metabolic regulator and transcriptional coactivator PGC-1\{alpha\}. J. Biol. Chem. 2005, 280, 16456-16460. [CrossRef]

189. Lagouge, M.; Argmann, C.; Gerhart-Hines, Z.; Meziane, H.; Lerin, C.; Daussin, F.; Messadeq, N.; Milne, J.; Lambert, P.; Elliott, P.; et al. Resveratrol improves mitochondrial function and protects against metabolic disease by activating SIRT1 and PGC-1alpha. Cell 2006, 127, 1109-1122. [CrossRef]

190. Daitoku, H.; Hatta, M.; Matsuzaki, H.; Aratani, S.; Ohshima, T.; Miyagishi, M.; Nakajima, T.; Fukamizu, A. Silent information regulator 2 potentiates Foxo1-mediated transcription through its deacetylase activity. Proc. Natl. Acad. Sci. USA 2004, 101, 10042-10047. [CrossRef]

191. van der Horst, A.; Tertoolen, L.G.; de Vries-Smits, L.M.; Frye, R.A.; Medema, R.H.; Burgering, B.M. FOXO4 is acetylated upon peroxide stress and deacetylated by the longevity protein hSir2(SIRT1). J. Biol. Chem. 2004, 279, 28873-28879. [CrossRef] [PubMed]

192. Brunet, A.; Sweeney, L.B.; Sturgill, J.F.; Chua, K.F.; Greer, P.L.; Lin, Y.; Tran, H.; Ross, S.E.; Mostoslavsky, R.; Cohen, H.Y.; et al. Stress-dependent regulation of FOXO transcription factors by the SIRT1 deacetylase. Science 2004, 303, 2011-2015. [CrossRef] [PubMed]

193. Frescas, D.; Valenti, L.; Accili, D. Nuclear trapping of the forkhead transcription factor FoxO1 via Sirt-dependent deacetylation promotes expression of glucogenetic genes. J. Biol. Chem. 2005, 280, 20589-20595. [CrossRef] [PubMed]

194. Accili, D.; Arden, K.C. FoxOs at the crossroads of cellular metabolism, differentiation, and transformation. Cell 2004, 117, 421-426. [CrossRef]

195. Martins, R.; Lithgow, G.J.; Link, W. Long live FOXO: Unraveling the role of FOXO proteins in aging and longevity. Aging Cell 2016, 15, 196-207. [CrossRef]

196. Gross, D.N.; van den Heuvel, A.P.; Birnbaum, M.J. The role of FoxO in the regulation of metabolism. Oncogene 2008, 27, 2320-2336. [CrossRef] 
197. Canto, C.; Gerhart-Hines, Z.; Feige, J.N.; Lagouge, M.; Noriega, L.; Milne, J.C.; Elliott, P.J.; Puigserver, P.; Auwerx, J. AMPK regulates energy expenditure by modulating NAD+ metabolism and SIRT1 activity. Nature 2009, 458, 1056-1060. [CrossRef]

198. Fulco, M.; Cen, Y.; Zhao, P.; Hoffman, E.P.; McBurney, M.W.; Sauve, A.A.; Sartorelli, V. Glucose restriction inhibits skeletal myoblast differentiation by activating SIRT1 through AMPK-mediated regulation of Nampt. Dev. Cell 2008, 14, 661-673. [CrossRef]

199. Hou, X.; Xu, S.; Maitland-Toolan, K.A.; Sato, K.; Jiang, B.; Ido, Y.; Lan, F.; Walsh, K.; Wierzbicki, M.; Verbeuren, T.J.; et al. SIRT1 regulates hepatocyte lipid metabolism through activating AMP-activated protein kinase. J. Biol. Chem. 2008, 283, 20015-20026. [CrossRef]

200. Lan, F.; Cacicedo, J.M.; Ruderman, N.; Ido, Y. SIRT1 modulation of the acetylation status, cytosolic localization, and activity of LKB1. Possible role in AMP-activated protein kinase activation. J. Biol. Chem. 2008, 283, 27628-27635. [CrossRef]

201. Asher, G.; Gatfield, D.; Stratmann, M.; Reinke, H.; Dibner, C.; Kreppel, F.; Mostoslavsky, R.; Alt, F.W.; Schibler, U. SIRT1 regulates circadian clock gene expression through PER2 deacetylation. Cell 2008, 134, 317-328. [CrossRef] [PubMed]

202. Rutter, J.; Reick, M.; Wu, L.C.; McKnight, S.L. Regulation of clock and NPAS2 DNA binding by the redox state of NAD cofactors. Science 2001, 293, 510-514. [CrossRef] [PubMed]

203. Oike, H.; Kobori, M. Resveratrol regulates circadian clock genes in Rat-1 fibroblast cells. Biosci. Biotechnol. Biochem. 2008, 72, 3038-3040. [CrossRef] [PubMed]

204. Sun, L.; Wang, Y.; Song, Y.; Cheng, X.R.; Xia, S.; Rahman, M.R.; Shi, Y.; Le, G. Resveratrol restores the circadian rhythmic disorder of lipid metabolism induced by high-fat diet in mice. Biochem. Biophys. Res. Commun. 2015, 458, 86-91. [CrossRef]

205. Miranda, J.; Portillo, M.P.; Madrid, J.A.; Arias, N.; Macarulla, M.T.; Garaulet, M. Effects of resveratrol on changes induced by high-fat feeding on clock genes in rats. Br. J. Nutr. 2013, 110, 1421-1428. [CrossRef]

206. Nakahata, Y.; Kaluzova, M.; Grimaldi, B.; Sahar, S.; Hirayama, J.; Chen, D.; Guarente, L.P.; Sassone-Corsi, P. The NAD+-dependent deacetylase SIRT1 modulates CLOCK-mediated chromatin remodeling and circadian control. Cell 2008, 134, 329-340. [CrossRef]

207. Ramsey, K.M.; Yoshino, J.; Brace, C.S.; Abrassart, D.; Kobayashi, Y.; Marcheva, B.; Hong, H.K.; Chong, J.L.; Buhr, E.D.; Lee, C.; et al. Circadian clock feedback cycle through NAMPT-mediated NAD+ biosynthesis. Science 2009, 324, 651-654. [CrossRef]

208. Nakahata, Y.; Sahar, S.; Astarita, G.; Kaluzova, M.; Sassone-Corsi, P. Circadian control of the NAD+ salvage pathway by CLOCK-SIRT1. Science 2009, 324, 654-657. [CrossRef]

209. Peek, C.B.; Affinati, A.H.; Ramsey, K.M.; Kuo, H.Y.; Yu, W.; Sena, L.A.; Ilkayeva, O.; Marcheva, B.; Kobayashi, Y.; Omura, C.; et al. Circadian clock NAD+ cycle drives mitochondrial oxidative metabolism in mice. Science 2013, 342, 1243417. [CrossRef]

210. Sahar, S.; Masubuchi, S.; Eckel-Mahan, K.; Vollmer, S.; Galla, L.; Ceglia, N.; Masri, S.; Barth, T.K.; Grimaldi, B.; Oluyemi, O.; et al. Circadian control of fatty acid elongation by SIRT1 protein-mediated deacetylation of acetyl-coenzyme A synthetase 1. J. Biol. Chem. 2014, 289, 6091-6097. [CrossRef]

211. Hallows, W.C.; Lee, S.; Denu, J.M. Sirtuins deacetylate and activate mammalian acetyl-CoA synthetases. Proc. Natl. Acad. Sci. USA 2006, 103, 10230-10235. [CrossRef] [PubMed]

212. Nuclear Receptors Nomenclature Committee. A unified nomenclature system for the nuclear receptor superfamily. Cell 1999, 97, 161-163. [CrossRef]

213. Feige, J.N.; Gelman, L.; Michalik, L.; Desvergne, B.; Wahli, W. From molecular action to physiological outputs: Peroxisome proliferator-activated receptors are nuclear receptors at the crossroads of key cellular functions. Prog. Lipid. Res. 2006, 45, 120-159. [CrossRef] [PubMed]

214. Michalik, L.; Auwerx, J.; Berger, J.P.; Chatterjee, V.K.; Glass, C.K.; Gonzalez, F.J.; Grimaldi, P.A.; Kadowaki, T.; Lazar, M.A.; O’Rahilly, S.; et al. International Union of Pharmacology. LXI. Peroxisome proliferator-activated receptors. Pharmacol. Rev. 2006, 58, 726-741. [CrossRef]

215. Moller, D.E.; Berger, J.P. Role of PPARs in the regulation of obesity-related insulin sensitivity and inflammation. Int. J. Obes. Relat. Metab. Disord. 2003, 27 (Suppl. S3), S17-S21. [CrossRef]

216. Tan, C.K.; Zhuang, Y.; Wahli, W. Synthetic and natural Peroxisome Proliferator-Activated Receptor (PPAR) agonists as candidates for the therapy of the metabolic syndrome. Expert. Opin. Ther. Targets 2017, 21, 333-348. [CrossRef] 
217. Cheng, H.S.; Tan, W.R.; Low, Z.S.; Marvalim, C.; Lee, J.Y.H.; Tan, N.S. Exploration and development of PPAR modulators in health and disease: An update of clinical evidence. Int. J. Mol. Sci. 2019, 20, 5055. [CrossRef]

218. Desvergne, B.; Wahli, W. Peroxisome proliferator-activated receptors: Nuclear control of metabolism. Endocr. Rev. 1999, 20, 649-688. [CrossRef]

219. Green, S.; Wahli, W. Peroxisome proliferator-activated receptors: Finding the orphan a home. Mol. Cell Endocrinol. 1994, 100, 149-153. [CrossRef]

220. Masternak, M.M.; Bartke, A. PPARs in calorie restricted and genetically long-lived mice. PPAR Res. 2007, 2007, 28436. [CrossRef]

221. Yang, Y.B.; Wu, X.L.; Ke, B.; Huang, Y.J.; Chen, S.Q.; Su, Y.Q.; Qin, J. Effects of caloric restriction on peroxisome proliferator-activated receptors and positive transcription elongation factor $\mathrm{b}$ expression in obese rats. Eur. Rev. Med. Pharmacol. Sci. 2017, 21, 4369-4378. [PubMed]

222. Masternak, M.M.; Al-Regaiey, K.A.; Del Rosario Lim, M.M.; Jimenez-Ortega, V.; Panici, J.A.; Bonkowski, M.S.; Kopchick, J.J.; Wang, Z.; Bartke, A. Caloric restriction and growth hormone receptor knockout: Effects on expression of genes involved in insulin action in the heart. Exp. Gerontol. 2006, 41, 417-429. [CrossRef] [PubMed]

223. Masternak, M.M.; Al-Regaiey, K.A.; Del Rosario Lim, M.M.; Jimenez-Ortega, V.; Panici, J.A.; Bonkowski, M.S.; Kopchick, J.J.; Bartke, A. Effects of caloric restriction and growth hormone resistance on the expression level of peroxisome proliferator-activated receptors superfamily in liver of normal and long-lived growth hormone receptor/binding protein knockout mice. J. Gerontol. A Biol. Sci. Med. Sci. 2005, 60, 1394-1398. [CrossRef] [PubMed]

224. Masternak, M.M.; Al-Regaiey, K.; Bonkowski, M.S.; Panici, J.; Sun, L.; Wang, J.; Przybylski, G.K.; Bartke, A. Divergent effects of caloric restriction on gene expression in normal and long-lived mice. J. Gerontol. A Biol. Sci. Med. Sci. 2004, 59, 784-788. [CrossRef] [PubMed]

225. Masternak, M.M.; Al-Regaiey, K.A.; Del Rosario Lim, M.M.; Bonkowski, M.S.; Panici, J.A.; Przybylski, G.K.; Bartke, A. Caloric restriction results in decreased expression of peroxisome proliferator-activated receptor superfamily in muscle of normal and long-lived growth hormone receptor/binding protein knockout mice. J. Gerontol. A Biol. Sci. Med. Sci. 2005, 60, 1238-1245. [CrossRef]

226. Poynter, M.E.; Daynes, R.A. Peroxisome proliferator-activated receptor alpha activation modulates cellular redox status, represses nuclear factor-kappaB signaling, and reduces inflammatory cytokine production in aging. J. Biol. Chem. 1998, 273, 32833-32841. [CrossRef]

227. Duszka, K.; Ellero-Simatos, S.; Ow, G.S.; Defernez, M.; Paramalingam, E.; Tett, A.; Ying, S.; Konig, J.; Narbad, A.; Kuznetsov, V.A.; et al. Complementary intestinal mucosa and microbiota responses to caloric restriction. Sci. Rep. 2018, 8, 11338. [CrossRef]

228. Dhahbi, J.M.; Tsuchiya, T.; Kim, H.J.; Mote, P.L.; Spindler, S.R. Gene expression and physiologic responses of the heart to the initiation and withdrawal of caloric restriction. J. Gerontol. A Biol. Sci. Med. Sci. 2006, 61, 218-231. [CrossRef]

229. Sung, B.; Park, S.; Yu, B.P.; Chung, H.Y. Modulation of PPAR in aging, inflammation, and calorie restriction. J. Gerontol. A Biol. Sci. Med. Sci. 2004, 59, 997-1006. [CrossRef]

230. Nakamura, K.; Inoue, I.; Takahashi, S.; Komoda, T.; Katayama, S. Cryptochrome and period proteins are regulated by the CLOCK/BMAL1 Gene: Crosstalk between the PPARs/RXR alpha-regulated and CLOCK/BMAL1-regulated systems. PPAR Res. 2008, 2008, 348610. [CrossRef]

231. Braissant, O.; Foufelle, F.; Scotto, C.; Dauca, M.; Wahli, W. Differential expression of peroxisome proliferator-activated receptors (PPARs): Tissue distribution of PPAR-alpha, -beta, and -gamma in the adult rat. Endocrinology 1996, 137, 354-366. [CrossRef] [PubMed]

232. Corton, J.C.; Apte, U.; Anderson, S.P.; Limaye, P.; Yoon, L.; Latendresse, J.; Dunn, C.; Everitt, J.I.; Voss, K.A.; Swanson, C.; et al. Mimetics of caloric restriction include agonists of lipid-activated nuclear receptors. J. Biol. Chem. 2004, 279, 46204-46212. [CrossRef] [PubMed]

233. Peeters, A.; Baes, M. Role of PPAR in hepatic carbohydrate metabolism. PPAR Res. 2010, $2010,572405$. [CrossRef] [PubMed]

234. Xu, J.; Xiao, G.; Trujillo, C.; Chang, V.; Blanco, L.; Joseph, S.B.; Bassilian, S.; Saad, M.F.; Tontonoz, P.; Lee, W.N.; et al. Peroxisome proliferator-activated receptor alpha (PPARalpha) influences substrate utilization for hepatic glucose production. J. Biol. Chem. 2002, 277, 50237-50244. [CrossRef] [PubMed] 
235. Mandard, S.; Stienstra, R.; Escher, P.; Tan, N.S.; Kim, I.; Gonzalez, F.J.; Wahli, W.; Desvergne, B.; Muller, M.; Kersten, S. Glycogen synthase 2 is a novel target gene of peroxisome proliferator-activated receptors. Cell Mol. Life Sci. 2007, 64, 1145-1157. [CrossRef] [PubMed]

236. Finck, B.N.; Lehman, J.J.; Leone, T.C.; Welch, M.J.; Bennett, M.J.; Kovacs, A.; Han, X.; Gross, R.W.; Kozak, R.; Lopaschuk, G.D.; et al. The cardiac phenotype induced by PPARalpha overexpression mimics that caused by diabetes mellitus. J. Clin. Investig. 2002, 109, 121-130. [CrossRef] [PubMed]

237. Gremlich, S.; Nolan, C.; Roduit, R.; Burcelin, R.; Peyot, M.L.; Delghingaro-Augusto, V.; Desvergne, B.; Michalik, L.; Prentki, M.; Wahli, W. Pancreatic islet adaptation to fasting is dependent on peroxisome proliferator-activated receptor alpha transcriptional up-regulation of fatty acid oxidation. Endocrinology 2005, 146, 375-382. [CrossRef]

238. Ravnskjaer, K.; Boergesen, M.; Rubi, B.; Larsen, J.K.; Nielsen, T.; Fridriksson, J.; Maechler, P.; Mandrup, S. Peroxisome proliferator-activated receptor alpha (PPARalpha) potentiates, whereas PPARgamma attenuates, glucose-stimulated insulin secretion in pancreatic beta-cells. Endocrinology 2005, 146, 3266-3276. [CrossRef]

239. Maida, A.; Lamont, B.J.; Cao, X.; Drucker, D.J. Metformin regulates the incretin receptor axis via a pathway dependent on peroxisome proliferator-activated receptor-alpha in mice. Diabetologia 2011, 54, 339-349. [CrossRef]

240. Sugden, M.C.; Greenwood, G.K.; Smith, N.D.; Holness, M.J. Peroxisome proliferator-activated receptor-alpha activation during pregnancy attenuates glucose-stimulated insulin hypersecretion in vivo by increasing insulin sensitivity, without impairing pregnancy-induced increases in beta-cell glucose sensing and responsiveness. Endocrinology 2003, 144, 146-153. [CrossRef]

241. Murakami, K.; Nambu, S.; Koh, H.; Kobayashi, M.; Shigeta, Y. Clofibrate enhances the affinity of insulin receptors in non-insulin dependent diabetes mellitus. Br. J. Clin. Pharmacol. 1984, 17, 89-91. [CrossRef] [PubMed]

242. Kobayashi, M.; Shigeta, Y.; Hirata, Y.; Omori, Y.; Sakamoto, N.; Nambu, S.; Baba, S. Improvement of glucose tolerance in NIDDM by clofibrate. Randomized double-blind study. Diabetes Care 1988, 11, 495-499. [CrossRef]

243. Guerre-Millo, M.; Gervois, P.; Raspe, E.; Madsen, L.; Poulain, P.; Derudas, B.; Herbert, J.M.; Winegar, D.A.; Willson, T.M.; Fruchart, J.C.; et al. Peroxisome proliferator-activated receptor alpha activators improve insulin sensitivity and reduce adiposity. J. Biol. Chem. 2000, 275, 16638-16642. [CrossRef] [PubMed]

244. Aasum, E.; Belke, D.D.; Severson, D.L.; Riemersma, R.A.; Cooper, M.; Andreassen, M.; Larsen, T.S. Cardiac function and metabolism in Type 2 diabetic mice after treatment with BM 17.0744, a novel PPAR-alpha activator. Am. J. Physiol. Heart Circ. Physiol. 2002, 283, H949-H957. [CrossRef] [PubMed]

245. Patsouris, D.; Mandard, S.; Voshol, P.J.; Escher, P.; Tan, N.S.; Havekes, L.M.; Koenig, W.; Marz, W.; Tafuri, S.; Wahli, W.; et al. PPARalpha governs glycerol metabolism. J. Clin. Investig. 2004, 114, 94-103. [CrossRef] [PubMed]

246. Lalloyer, F.; Vandewalle, B.; Percevault, F.; Torpier, G.; Kerr-Conte, J.; Oosterveer, M.; Paumelle, R.; Fruchart, J.C.; Kuipers, F.; Pattou, F.; et al. Peroxisome proliferator-activated receptor alpha improves pancreatic adaptation to insulin resistance in obese mice and reduces lipotoxicity in human islets. Diabetes 2006, 55, 1605-1613. [CrossRef] [PubMed]

247. Sugden, M.C.; Bulmer, K.; Gibbons, G.F.; Knight, B.L.; Holness, M.J. Peroxisome-proliferator-activated receptor-alpha (PPARalpha) deficiency leads to dysregulation of hepatic lipid and carbohydrate metabolism by fatty acids and insulin. Biochem. J. 2002, 364, 361-368. [CrossRef] [PubMed]

248. Kersten, S.; Seydoux, J.; Peters, J.M.; Gonzalez, F.J.; Desvergne, B.; Wahli, W. Peroxisome proliferator-activated receptor alpha mediates the adaptive response to fasting. J. Clin. Investig. 1999, 103, 1489-1498. [CrossRef] [PubMed]

249. Hashimoto, T.; Cook, W.S.; Qi, C.; Yeldandi, A.V.; Reddy, J.K.; Rao, M.S. Defect in peroxisome proliferator-activated receptor alpha-inducible fatty acid oxidation determines the severity of hepatic steatosis in response to fasting. J. Biol. Chem. 2000, 275, 28918-28928. [CrossRef] [PubMed]

250. Leone, T.C.; Weinheimer, C.J.; Kelly, D.P. A critical role for the peroxisome proliferator-activated receptor alpha (PPARalpha) in the cellular fasting response: The PPARalpha-null mouse as a model of fatty acid oxidation disorders. Proc. Natl. Acad. Sci. USA 1999, 96, 7473-7478. [CrossRef] [PubMed] 
251. Fu, J.; Gaetani, S.; Oveisi, F.; Verme, J.L.; Serrano, A.; De Fonseca, F.R.; Rosengarth, A.; Luecke, H.; Di Giacomo, B.; Tarzia, G.; et al. Oleylethanolamide regulates feeding and body weight through activation of the nuclear receptor PPAR- $\alpha$. Nat. Cell Biol. 2003, 425, 90-93. [CrossRef] [PubMed]

252. Fu, J.; DiPatrizio, N.V.; Guijarro, A.; Schwartz, G.J.; Li, X.; Gaetani, S.; Astarita, G.; Piomelli, D. Sympathetic activity controls fat-induced oleoylethanolamide signaling in small intestine. J. Neurosci. 2011, 31, 5730-5736. [CrossRef] [PubMed]

253. Magotti, P.; Bauer, I.; Igarashi, M.; Babagoli, M.; Marotta, R.; Piomelli, D.; Garau, G. Structure of Human N -Acylphosphatidylethanolamine-Hydrolyzing Phospholipase D: Regulation of Fatty Acid Ethanolamide Biosynthesis by Bile Acids. Structure 2015, 23, 598-604. [CrossRef] [PubMed]

254. Gaetani, S.; Oveisi, F.; Piomelli, D. Modulation of Meal Pattern in the Rat by the Anorexic Lipid Mediator Oleoylethanolamide. Neuropsychopharmacology 2003, 28, 1311-1316. [CrossRef] [PubMed]

255. Fu, J.; Oveisi, F.; Gaetani, S.; Lin, E.; Piomelli, D. Oleoylethanolamide, an endogenous PPAR- $\alpha$ agonist, lowers body weight and hyperlipidemia in obese rats. Neuropharmacology 2005, 48, 1147-1153. [CrossRef] [PubMed]

256. Caillon, A.; Duszka, K.; Wahli, W.; Rohner-Jeanrenaud, F.; Altirriba, J. The OEA effect on food intake is independent from the presence of PPAR $\alpha$ in the intestine and the nodose ganglion, while the impact of OEA on energy expenditure requires the presence of PPAR $\alpha$ in mice. Metabolism 2018, 87, 13-17. [CrossRef] [PubMed]

257. De Fonseca, F.R.; Navarro, M.; Gómez, R.; Escuredo, L.; Nava, F.; Fu, J.; Murillo-Rodríguez, E.; Giuffrida, A.; LoVerme, J.; Gaetani, S.; et al. An anorexic lipid mediator regulated by feeding. Nat. Cell Biol. 2001, 414, 209-212. [CrossRef]

258. Gaetani, S.; Fu, J.; Cassano, T.; DiPasquale, P.; Romano, A.; Righetti, L.; Cianci, S.; Laconca, L.; Giannini, E.; Scaccianoce, S.; et al. The fat-induced satiety factor oleoylethanolamide suppresses feeding through central release of oxytocin. J. Neurosci. 2010, 30, 8096-8101. [CrossRef]

259. Hankir, M.K.; Seyfried, F.; Hintschich, C.A.; Diep, T.-A.; Kleberg, K.; Kranz, M.; Deuther-Conrad, W.; Tellez, L.A.; Rullmann, M.; Patt, M.; et al. Gastric Bypass Surgery Recruits a Gut PPAR- $\alpha$-Striatal D1R Pathway to Reduce Fat Appetite in Obese Rats. Cell Metab. 2017, 25, 335-344. [CrossRef]

260. Pan, W.; Liu, C.; Zhang, J.; Gao, X.; Yu, S.; Tan, H.; Yu, J.; Qian, D.; Li, J.; Bian, S.; et al. Association Between Single Nucleotide Polymorphisms in PPARA and EPAS1 Genes and High-Altitude Appetite Loss in Chinese Young Men. Front. Physiol. 2019, 10. [CrossRef]

261. Chakravarthy, M.V.; Zhu, Y.; López, M.; Yin, L.; Wozniak, D.F.; Coleman, T.; Hu, Z.; Wolfgang, M.; Vidal-Puig, A.; Lane, M.D.; et al. Brain fatty acid synthase activates PPAR $\alpha$ to maintain energy homeostasis. J. Clin. Investig. 2007, 117, 2539-2552. [CrossRef] [PubMed]

262. Iroz, A.; Montagner, A.; Benhamed, F.; Levavasseur, F.; Polizzi, A.; Anthony, E.; Régnier, M.; Fouché, E.; Lukowicz, C.; Cauzac, M.; et al. A Specific ChREBP and PPAR $\alpha$ Cross-Talk Is Required for the Glucose-Mediated FGF21 Response. Cell Rep. 2017, 21, 403-416. [CrossRef] [PubMed]

263. Laeger, T.; Henagan, T.M.; Albarado, D.C.; Redman, L.M.; Bray, G.A.; Noland, R.C.; Münzberg, H.; Hutson, S.M.; Gettys, T.W.; Schwartz, M.W.; et al. FGF21 is an endocrine signal of protein restriction. J. Clin. Investig. 2014, 124, 3913-3922. [CrossRef] [PubMed]

264. Sengupta, S.; Peterson, T.R.; Laplante, M.; Oh, S.; Sabatini, D.M. mTORC1 controls fasting-induced ketogenesis and its modulation by ageing. Nature 2010, 468, 1100-1104. [CrossRef] [PubMed]

265. Pawlak, M.; Lefebvre, P.; Staels, B. Molecular mechanism of PPARalpha action and its impact on lipid metabolism, inflammation and fibrosis in non-alcoholic fatty liver disease. J. Hepatol. 2015, 62, 720-733. [CrossRef] [PubMed]

266. Pentinmikko, N.; Iqbal, S.; Mana, M.; Andersson, S.; Cognetta, A.B., 3rd; Suciu, R.M.; Roper, J.; Luopajarvi, K.; Markelin, E.; Gopalakrishnan, S.; et al. Notum produced by Paneth cells attenuates regeneration of aged intestinal epithelium. Nature 2019, 571, 398-402. [CrossRef] [PubMed]

267. Okuda, Y.; Kawai, K.; Yamashita, K. Age-related change in ketone body metabolism: Diminished glucagon effect on ketogenesis in adult rats. Endocrinology 1987, 120, 2152-2157. [CrossRef]

268. Sanguino, E.; Ramon, M.; Michalik, L.; Wahli, W.; Alegret, M.; Sanchez, R.M.; Vazquez-Carrera, M.; Laguna, J.C. Lack of hypotriglyceridemic effect of gemfibrozil as a consequence of age-related changes in rat liver PPARalpha. Biochem. Pharmacol. 2004, 67, 157-166. [CrossRef] 
269. Sastre, J.; Pallardo, F.V.; Pla, R.; Pellin, A.; Juan, G.; O'Connor, J.E.; Estrela, J.M.; Miquel, J.; Vina, J. Aging of the liver: Age-associated mitochondrial damage in intact hepatocytes. Hepatology 1996, 24, 1199-1205. [CrossRef]

270. Jiao, M.; Ren, F.; Zhou, L.; Zhang, X.; Zhang, L.; Wen, T.; Wei, L.; Wang, X.; Shi, H.; Bai, L.; et al. Peroxisome proliferator-activated receptor alpha activation attenuates the inflammatory response to protect the liver from acute failure by promoting the autophagy pathway. Cell Death Dis. 2014, 5, e1397. [CrossRef]

271. Kim, Y.S.; Lee, H.M.; Kim, J.K.; Yang, C.S.; Kim, T.S.; Jung, M.; Jin, H.S.; Kim, S.; Jang, J.; Oh, G.T.; et al. PPAR-alpha Activation Mediates Innate Host Defense through Induction of TFEB and Lipid Catabolism. J. Immunol. 2017, 198, 3283-3295. [CrossRef] [PubMed]

272. Hardie, D.G.; Carling, D.; Carlson, M. The AMP-activated/SNF1 protein kinase subfamily: Metabolic sensors of the eukaryotic cell? Annu. Rev. Biochem. 1998, 67, 821-855. [CrossRef] [PubMed]

273. Viollet, B.; Andreelli, F. AMP-activated protein kinase and metabolic control. Handb. Exp. Pharmacol. 2011, 13, 303-330. [CrossRef]

274. Lee, W.J.; Kim, M.; Park, H.S.; Kim, H.S.; Jeon, M.J.; Oh, K.S.; Koh, E.H.; Won, J.C.; Kim, M.S.; Oh, G.T.; et al. AMPK activation increases fatty acid oxidation in skeletal muscle by activating PPARalpha and PGC-1. Biochem. Biophys. Res. Commun. 2006, 340, 291-295. [CrossRef] [PubMed]

275. Yoon, M.J.; Lee, G.Y.; Chung, J.J.; Ahn, Y.H.; Hong, S.H.; Kim, J.B. Adiponectin increases fatty acid oxidation in skeletal muscle cells by sequential activation of AMP-activated protein kinase, p38 mitogen-activated protein kinase, and peroxisome proliferator-activated receptor alpha. Diabetes 2006, 55, 2562-2570. [CrossRef] [PubMed]

276. Bai, F.; Liu, Y.; Tu, T.; Li, B.; Xiao, Y.; Ma, Y.; Qin, F.; Xie, J.; Zhou, S.; Liu, Q. Metformin regulates lipid metabolism in a canine model of atrial fibrillation through AMPK/PPAR-alpha/VLCAD pathway. Lipids Health Dis. 2019, 18, 109. [CrossRef]

277. Joly, E.; Roduit, R.; Peyot, M.L.; Habinowski, S.A.; Ruderman, N.B.; Witters, L.A.; Prentki, M. Glucose represses PPARalpha gene expression via AMP-activated protein kinase but not via p38 mitogen-activated protein kinase in the pancreatic beta-cell. J. Diabetes 2009, 1, 263-272. [CrossRef]

278. Ravnskjaer, K.; Boergesen, M.; Dalgaard, L.T.; Mandrup, S. Glucose-induced repression of PPARalpha gene expression in pancreatic beta-cells involves PP2A activation and AMPK inactivation. J. Mol. Endocrinol. 2006, 36, 289-299. [CrossRef]

279. Bronner, M.; Hertz, R.; Bar-Tana, J. Kinase-independent transcriptional co-activation of peroxisome proliferator-activated receptor alpha by AMP-activated protein kinase. Biochem. J. 2004, 384, 295-305. [CrossRef]

280. Manickam, R.; Duszka, K.; Wahli, W. PPARs and Microbiota in Skeletal Muscle Health and Wasting. Int. J. Mol. Sci. 2020, 21, 8056. [CrossRef]

281. Chanda, D.; Lee, C.H.; Kim, Y.H.; Noh, J.R.; Kim, D.K.; Park, J.H.; Hwang, J.H.; Lee, M.R.; Jeong, K.H.; Lee, I.K.; et al. Fenofibrate differentially regulates plasminogen activator inhibitor-1 gene expression via adenosine monophosphate-activated protein kinase-dependent induction of orphan nuclear receptor small heterodimer partner. Hepatology 2009, 50, 880-892. [CrossRef] [PubMed]

282. Liangpunsakul, S.; Wou, S.E.; Wineinger, K.D.; Zeng, Y.; Cyganek, I.; Jayaram, H.N.; Crabb, D.W. Effects of WY-14,643 on the phosphorylation and activation of AMP-dependent protein kinase. Arch. Biochem. Biophys. 2009, 485, 10-15. [CrossRef] [PubMed]

283. Ren, G.; Rimando, A.M.; Mathews, S.T. AMPK activation by pterostilbene contributes to suppression of hepatic gluconeogenic gene expression and glucose production in H4IIE cells. Biochem. Biophys. Res. Commun. 2018, 498, 640-645. [CrossRef] [PubMed]

284. Purushotham, A.; Schug, T.T.; Xu, Q.; Surapureddi, S.; Guo, X.; Li, X. Hepatocyte-specific deletion of SIRT1 alters fatty acid metabolism and results in hepatic steatosis and inflammation. Cell Metab. 2009, 9, 327-338. [CrossRef] [PubMed]

285. Oka, S.; Alcendor, R.; Zhai, P.; Park, J.Y.; Shao, D.; Cho, J.; Yamamoto, T.; Tian, B.; Sadoshima, J. PPARalpha-Sirt1 complex mediates cardiac hypertrophy and failure through suppression of the ERR transcriptional pathway. Cell Metab. 2011, 14, 598-611. [CrossRef]

286. Oka, S.; Zhai, P.; Alcendor, R.; Park, J.Y.; Tian, B.; Sadoshima, J. Suppression of ERR targets by a PPARalpha/Sirt1 complex in the failing heart. Cell Cycle 2012, 11, 856-864. [CrossRef] 
287. Planavila, A.; Iglesias, R.; Giralt, M.; Villarroya, F. Sirt1 acts in association with PPARalpha to protect the heart from hypertrophy, metabolic dysregulation, and inflammation. Cardiovasc. Res. 2011, 90, 276-284. [CrossRef]

288. Yang, X.; Downes, M.; Yu, R.T.; Bookout, A.L.; He, W.; Straume, M.; Mangelsdorf, D.J.; Evans, R.M. Nuclear receptor expression links the circadian clock to metabolism. Cell 2006, 126, 801-810. [CrossRef]

289. Lemberger, T.; Saladin, R.; Vazquez, M.; Assimacopoulos, F.; Staels, B.; Desvergne, B.; Wahli, W.; Auwerx, J. Expression of the peroxisome proliferator-activated receptor alpha gene is stimulated by stress and follows a diurnal rhythm. J. Biol. Chem. 1996, 271, 1764-1769. [CrossRef]

290. Canaple, L.; Rambaud, J.; Dkhissi-Benyahya, O.; Rayet, B.; Tan, N.S.; Michalik, L.; Delaunay, F.; Wahli, W.; Laudet, V. Reciprocal regulation of brain and muscle Arnt-like protein 1 and peroxisome proliferator-activated receptor alpha defines a novel positive feedback loop in the rodent liver circadian clock. Mol. Endocrinol. 2006, 20, 1715-1727. [CrossRef]

291. Oishi, K.; Shirai, H.; Ishida, N. CLOCK is involved in the circadian transactivation of peroxisome-proliferator-activated receptor alpha (PPARalpha) in mice. Biochem. J. 2005, 386, 575-581. [CrossRef] [PubMed]

292. Gervois, P.; Chopin-Delannoy, S.; Fadel, A.; Dubois, G.; Kosykh, V.; Fruchart, J.C.; Najib, J.; Laudet, V.; Staels, B. Fibrates increase human REV-ERBalpha expression in liver via a novel peroxisome proliferator-activated receptor response element. Mol. Endocrinol. 1999, 13, 400-409. [CrossRef] [PubMed]

293. Schmutz, I.; Ripperger, J.A.; Baeriswyl-Aebischer, S.; Albrecht, U. The mammalian clock component PERIOD2 coordinates circadian output by interaction with nuclear receptors. Genes Dev. 2010, 24, 345-357. [CrossRef] [PubMed]

294. Shirai, H.; Oishi, K.; Kudo, T.; Shibata, S.; Ishida, N. PPARalpha is a potential therapeutic target of drugs to treat circadian rhythm sleep disorders. Biochem. Biophys. Res. Commun. 2007, 357, 679-682. [CrossRef] [PubMed]

295. Oishi, K.; Shirai, H.; Ishida, N. PPARalpha is involved in photoentrainment of the circadian clock. Neuroreport 2008, 19, 487-489. [CrossRef]

296. Raspe, E.; Duez, H.; Mansen, A.; Fontaine, C.; Fievet, C.; Fruchart, J.C.; Vennstrom, B.; Staels, B. Identification of Rev-erbalpha as a physiological repressor of apoC-III gene transcription. J. Lipid Res. 2002, 43, 2172-2179. [CrossRef]

297. Turek, F.W.; Joshu, C.; Kohsaka, A.; Lin, E.; Ivanova, G.; McDearmon, E.; Laposky, A.; Losee-Olson, S.; Easton, A.; Jensen, D.R.; et al. Obesity and metabolic syndrome in circadian Clock mutant mice. Science 2005, 308, 1043-1045. [CrossRef]

298. Grimaldi, B.; Bellet, M.M.; Katada, S.; Astarita, G.; Hirayama, J.; Amin, R.H.; Granneman, J.G.; Piomelli, D.; Leff, T.; Sassone-Corsi, P. PER2 controls lipid metabolism by direct regulation of PPARgamma. Cell Metab. 2010, 12, 509-520. [CrossRef]

299. Dallmann, R.; Viola, A.U.; Tarokh, L.; Cajochen, C.; Brown, S.A. The human circadian metabolome. Proc. Natl. Acad. Sci. USA 2012, 109, 2625-2629. [CrossRef]

300. Chua, E.C.; Shui, G.; Lee, I.T.; Lau, P.; Tan, L.C.; Yeo, S.C.; Lam, B.D.; Bulchand, S.; Summers, S.A.; Puvanendran, K.; et al. Extensive diversity in circadian regulation of plasma lipids and evidence for different circadian metabolic phenotypes in humans. Proc. Natl. Acad. Sci. USA 2013, 110, 14468-14473. [CrossRef]

301. Pan, X.; Hussain, M.M. Diurnal regulation of microsomal triglyceride transfer protein and plasma lipid levels. J. Biol. Chem. 2007, 282, 24707-24719. [CrossRef] [PubMed]

302. Adamovich, Y.; Rousso-Noori, L.; Zwighaft, Z.; Neufeld-Cohen, A.; Golik, M.; Kraut-Cohen, J.; Wang, M.; Han, X.; Asher, G. Circadian clocks and feeding time regulate the oscillations and levels of hepatic triglycerides. Cell Metab. 2014, 19, 319-330. [CrossRef] [PubMed]

303. Zvonic, S.; Ptitsyn, A.A.; Conrad, S.A.; Scott, L.K.; Floyd, Z.E.; Kilroy, G.; Wu, X.; Goh, B.C.; Mynatt, R.L.; Gimble, J.M. Characterization of peripheral circadian clocks in adipose tissues. Diabetes 2006, 55, 962-970. [CrossRef] [PubMed]

304. Barger, P.M.; Kelly, D.P. PPAR signaling in the control of cardiac energy metabolism. Trends Cardiovasc. Med. 2000, 10, 238-245. [CrossRef]

305. Wu, X.; Liu, Z.; Shi, G.; Xing, L.; Wang, X.; Gu, X.; Qu, Z.; Dong, Z.; Xiong, J.; Gao, X.; et al. The circadian clock influences heart performance. J. Biol. Rhythms 2011, 26, 402-411. [CrossRef] [PubMed] 
306. Oishi, K.; Uchida, D.; Ishida, N. Circadian expression of FGF21 is induced by PPARalpha activation in the mouse liver. FEBS Lett. 2008, 582, 3639-3642. [CrossRef]

307. Patel, D.D.; Knight, B.L.; Wiggins, D.; Humphreys, S.M.; Gibbons, G.F. Disturbances in the normal regulation of SREBP-sensitive genes in PPAR alpha-deficient mice. J. Lipid Res. 2001, 42, 328-337.

308. Girroir, E.E.; Hollingshead, H.E.; He, P.; Zhu, B.; Perdew, G.H.; Peters, J.M. Quantitative expression patterns of peroxisome proliferator-activated receptor-beta/delta (PPARbeta/delta) protein in mice. Biochem. Biophys. Res. Commun 2008, 371, 456-461. [CrossRef]

309. Braissant, O.; Wahli, W. Differential expression of peroxisome proliferator-activated receptor-alpha, -beta, and -gamma during rat embryonic development. Endocrinology 1998, 139, 2748-2754. [CrossRef]

310. Tan, N.S.; Michalik, L.; Desvergne, B.; Wahli, W. Peroxisome proliferator-activated receptor (PPAR)-beta as a target for wound healing drugs: What is possible? Am. J. Clin. Dermatol. 2003, 4, 523-530. [CrossRef]

311. Di-Poi, N.; Tan, N.S.; Michalik, L.; Wahli, W.; Desvergne, B. Antiapoptotic role of PPARbeta in keratinocytes via transcriptional control of the Akt1 signaling pathway. Mol. Cell 2002, 10, 721-733. [CrossRef]

312. Letavernier, E.; Perez, J.; Joye, E.; Bellocq, A.; Fouqueray, B.; Haymann, J.P.; Heudes, D.; Wahli, W.; Desvergne, B.; Baud, L. Peroxisome proliferator-activated receptor beta/delta exerts a strong protection from ischemic acute renal failure. J. Am. Soc. Nephrol. 2005, 16, 2395-2402. [CrossRef] [PubMed]

313. Michalik, L.; Wahli, W. Involvement of PPAR nuclear receptors in tissue injury and wound repair. J. Clin. Investig. 2006, 116, 598-606. [CrossRef] [PubMed]

314. Wang, Y.X.; Lee, C.H.; Tiep, S.; Yu, R.T.; Ham, J.; Kang, H.; Evans, R.M. Peroxisome-proliferator-activated receptor delta activates fat metabolism to prevent obesity. Cell 2003, 113, 159-170. [CrossRef]

315. Nadra, K.; Anghel, S.I.; Joye, E.; Tan, N.S.; Basu-Modak, S.; Trono, D.; Wahli, W.; Desvergne, B. Differentiation of trophoblast giant cells and their metabolic functions are dependent on peroxisome proliferator-activated receptor beta/delta. Mol. Cell Biol. 2006, 26, 3266-3281. [CrossRef]

316. Varnat, F.; Heggeler, B.B.; Grisel, P.; Boucard, N.; Corthesy-Theulaz, I.; Wahli, W.; Desvergne, B. PPARbeta/delta regulates paneth cell differentiation via controlling the hedgehog signaling pathway. Gastroenterology 2006, 131, 538-553. [CrossRef] [PubMed]

317. Doktorova, M.; Zwarts, I.; Zutphen, T.V.; Dijk, T.H.; Bloks, V.W.; Harkema, L.; Bruin, A.; Downes, M.; Evans, R.M.; Verkade, H.J.; et al. Intestinal PPARdelta protects against diet-induced obesity, insulin resistance and dyslipidemia. Sci. Rep. 2017, 7, 846. [CrossRef] [PubMed]

318. Dreyer, C.; Krey, G.; Keller, H.; Givel, F.; Helftenbein, G.; Wahli, W. Control of the peroxisomal beta-oxidation pathway by a novel family of nuclear hormone receptors. Cell 1992, 68, 879-887. [CrossRef]

319. Daoudi, M.; Hennuyer, N.; Borland, M.G.; Touche, V.; Duhem, C.; Gross, B.; Caiazzo, R.; Kerr-Conte, J.; Pattou, F.; Peters, J.M.; et al. PPARbeta/delta activation induces enteroendocrine L cell GLP-1 production. Gastroenterology 2011, 140, 1564-1574. [CrossRef]

320. Schuler, M.; Ali, F.; Chambon, C.; Duteil, D.; Bornert, J.M.; Tardivel, A.; Desvergne, B.; Wahli, W.; Chambon, P.; Metzger, D. PGC1alpha expression is controlled in skeletal muscles by PPARbeta, whose ablation results in fiber-type switching, obesity, and type 2 diabetes. Cell Metab. 2006, 4, 407-414. [CrossRef]

321. Liu, S.; Brown, J.D.; Stanya, K.J.; Homan, E.; Leidl, M.; Inouye, K.; Bhargava, P.; Gangl, M.R.; Dai, L.; Hatano, B.; et al. A diurnal serum lipid integrates hepatic lipogenesis and peripheral fatty acid use. Nature 2013, 502, 550-554. [CrossRef] [PubMed]

322. Philp, A.; MacKenzie, M.G.; Belew, M.Y.; Towler, M.C.; Corstorphine, A.; Papalamprou, A.; Hardie, D.G.; Baar, K. Glycogen content regulates peroxisome proliferator activated receptor- partial differential (PPARpartial differential) activity in rat skeletal muscle. PLoS ONE 2013, 8, e77200. [CrossRef] [PubMed]

323. Manickam, R.; Wahli, W. Roles of Peroxisome Proliferator-Activated Receptor beta/delta in skeletal muscle physiology. Biochimie 2017, 136, 42-48. [CrossRef] [PubMed]

324. Wang, Y.X.; Zhang, C.L.; Yu, R.T.; Cho, H.K.; Nelson, M.C.; Bayuga-Ocampo, C.R.; Ham, J.; Kang, H.; Evans, R.M. Regulation of muscle fiber type and running endurance by PPAR delta. PLoS Biol. 2004, 2, e294. [CrossRef] [PubMed]

325. Kocalis, H.E.; Turney, M.K.; Printz, R.L.; Laryea, G.N.; Muglia, L.J.; Davies, S.S.; Stanwood, G.D.; McGuinness, O.P.; Niswender, K.D. Neuron-Specific Deletion of Peroxisome Proliferator-Activated Receptor Delta (PPARס) in Mice Leads to Increased Susceptibility to Diet-Induced Obesity. PLoS ONE 2012, 7, e42981. [CrossRef] [PubMed] 
326. Foster, D.A. Phosphatidic acid and lipid-sensing by mTOR. Trends Endocrinol. Metab. 2013, 24, $272-278$. [CrossRef] [PubMed]

327. Sun, X.; Ritzenthaler, J.D.; Zhong, X.; Zheng, Y.; Roman, J.; Han, S. Nicotine stimulates PPARbeta/delta expression in human lung carcinoma cells through activation of PI3K/mTOR and suppression of AP-2 alpha. Cancer Res. 2009, 69, 6445-6453. [CrossRef] [PubMed]

328. Han, S.; Ritzenthaler, J.D.; Zheng, Y.; Roman, J. PPARbeta/delta agonist stimulates human lung carcinoma cell growth through inhibition of PTEN expression: The involvement of PI3K and NF-kappa B signals. Am. J. Physiol. Lung Cell Mol. Physiol. 2008, 294, L1238-L1249. [CrossRef] [PubMed]

329. Oliver, W.R., Jr.; Shenk, J.L.; Snaith, M.R.; Russell, C.S.; Plunket, K.D.; Bodkin, N.L.; Lewis, M.C.; Winegar, D.A.; Sznaidman, M.L.; Lambert, M.H.; et al. A selective peroxisome proliferator-activated receptor delta agonist promotes reverse cholesterol transport. Proc. Natl. Acad. Sci. USA 2001, 98, 5306-5311. [CrossRef]

330. Tanaka, T.; Yamamoto, J.; Iwasaki, S.; Asaba, H.; Hamura, H.; Ikeda, Y.; Watanabe, M.; Magoori, K.; Ioka, R.X.; Tachibana, K.; et al. Activation of peroxisome proliferator-activated receptor delta induces fatty acid beta-oxidation in skeletal muscle and attenuates metabolic syndrome. Proc. Natl. Acad. Sci. USA 2003, 100, 15924-15929. [CrossRef]

331. Riserus, U.; Sprecher, D.; Johnson, T.; Olson, E.; Hirschberg, S.; Liu, A.; Fang, Z.; Hegde, P.; Richards, D.; Sarov-Blat, L.; et al. Activation of peroxisome proliferator-activated receptor (PPAR)delta promotes reversal of multiple metabolic abnormalities, reduces oxidative stress, and increases fatty acid oxidation in moderately obese men. Diabetes 2008, 57, 332-339. [CrossRef] [PubMed]

332. Cohen, G.; Riahi, Y.; Shamni, O.; Guichardant, M.; Chatgilialoglu, C.; Ferreri, C.; Kaiser, N.; Sasson, S. Role of lipid peroxidation and PPAR-delta in amplifying glucose-stimulated insulin secretion. Diabetes 2011, 60, 2830-2842. [CrossRef] [PubMed]

333. Iglesias, J.; Barg, S.; Vallois, D.; Lahiri, S.; Roger, C.; Yessoufou, A.; Pradevand, S.; McDonald, A.; Bonal, C.; Reimann, F.; et al. PPARbeta/delta affects pancreatic beta cell mass and insulin secretion in mice. J. Clin. Investig. 2012, 122, 4105-4117. [CrossRef] [PubMed]

334. Serrano-Marco, L.; Rodriguez-Calvo, R.; El Kochairi, I.; Palomer, X.; Michalik, L.; Wahli, W.; Vazquez-Carrera, M. Activation of peroxisome proliferator-activated receptor-beta/-delta (PPAR-beta/-delta) ameliorates insulin signaling and reduces SOCS3 levels by inhibiting STAT3 in interleukin-6-stimulated adipocytes. Diabetes 2011, 60, 1990-1999. [CrossRef] [PubMed]

335. Serrano-Marco, L.; Barroso, E.; El Kochairi, I.; Palomer, X.; Michalik, L.; Wahli, W.; Vazquez-Carrera, M. The peroxisome proliferator-activated receptor (PPAR) beta/delta agonist GW501516 inhibits IL-6-induced signal transducer and activator of transcription 3 (STAT3) activation and insulin resistance in human liver cells. Diabetologia 2012, 55, 743-751. [CrossRef]

336. Salvado, L.; Barroso, E.; Gomez-Foix, A.M.; Palomer, X.; Michalik, L.; Wahli, W.; Vazquez-Carrera, M. PPARbeta/delta prevents endoplasmic reticulum stress-associated inflammation and insulin resistance in skeletal muscle cells through an AMPK-dependent mechanism. Diabetologia 2014, 57, 2126-2135. [CrossRef]

337. Lee, C.H.; Olson, P.; Hevener, A.; Mehl, I.; Chong, L.W.; Olefsky, J.M.; Gonzalez, F.J.; Ham, J.; Kang, H.; Peters, J.M.; et al. PPARdelta regulates glucose metabolism and insulin sensitivity. Proc. Natl. Acad. Sci. USA 2006, 103, 3444-3449. [CrossRef]

338. Gan, Z.; Burkart-Hartman, E.M.; Han, D.H.; Finck, B.; Leone, T.C.; Smith, E.Y.; Ayala, J.E.; Holloszy, J.; Kelly, D.P. The nuclear receptor PPARbeta/delta programs muscle glucose metabolism in cooperation with AMPK and MEF2. Genes Dev. 2011, 25, 2619-2630. [CrossRef] [PubMed]

339. Manio, M.C.; Inoue, K.; Fujitani, M.; Matsumura, S.; Fushiki, T. Combined pharmacological activation of AMPK and PPARdelta potentiates the effects of exercise in trained mice. Physiol Rep. 2016, 4. [CrossRef]

340. Narkar, V.A.; Downes, M.; Yu, R.T.; Embler, E.; Wang, Y.X.; Banayo, E.; Mihaylova, M.M.; Nelson, M.C.; Zou, Y.; Juguilon, H.; et al. AMPK and PPARdelta agonists are exercise mimetics. Cell 2008, 134, 405-415. [CrossRef]

341. Okazaki, M.; Iwasaki, Y.; Nishiyama, M.; Taguchi, T.; Tsugita, M.; Nakayama, S.; Kambayashi, M.; Hashimoto, K.; Terada, Y. PPARbeta/delta regulates the human SIRT1 gene transcription via Sp1. Endocr. J. 2010, 57, 403-413. [CrossRef] [PubMed] 
342. Barroso, E.; Eyre, E.; Palomer, X.; Vazquez-Carrera, M. The peroxisome proliferator-activated receptor beta/delta (PPARbeta/delta) agonist GW501516 prevents TNF-alpha-induced NF-kappaB activation in human HaCaT cells by reducing p65 acetylation through AMPK and SIRT1. Biochem. Pharmacol. 2011, 81, 534-543. [CrossRef] [PubMed]

343. Kim, M.Y.; Kang, E.S.; Ham, S.A.; Hwang, J.S.; Yoo, T.S.; Lee, H.; Paek, K.S.; Park, C.; Lee, H.T.; Kim, J.H.; et al. The PPARdelta-mediated inhibition of angiotensin II-induced premature senescence in human endothelial cells is SIRT1-dependent. Biochem. Pharmacol. 2012, 84, 1627-1634. [CrossRef] [PubMed]

344. Gong, K.; Qu, B.; Wang, C.; Zhou, J.; Liao, D.; Zheng, W.; Pan, X. Peroxisome proliferator-activated receptor alpha facilitates osteogenic differentiation in MC3T3-E1 cells via the sirtuin 1-dependent signaling pathway. Mol. Cells 2017, 40, 393-400. [CrossRef] [PubMed]

345. Gong, K.; Qu, B.; Liao, D.; Liu, D.; Wang, C.; Zhou, J.; Pan, X. MiR-132 regulates osteogenic differentiation via downregulating Sirtuin1 in a peroxisome proliferator-activated receptor beta/delta-dependent manner. Biochem. Biophys. Res. Commun. 2016, 478, 260-267. [CrossRef] [PubMed]

346. Qu, B.; Ma, Y.; Yan, M.; Gong, K.; Liang, F.; Deng, S.; Jiang, K.; Ma, Z.; Pan, X. Sirtuin1 promotes osteogenic differentiation through downregulation of peroxisome proliferator-activated receptor gamma in MC3T3-E1 cells. Biochem. Biophys. Res. Commun. 2016, 478, 439-445. [CrossRef] [PubMed]

347. Gatfield, D.; Le Martelot, G.; Vejnar, C.E.; Gerlach, D.; Schaad, O.; Fleury-Olela, F.; Ruskeepaa, A.L.; Oresic, M.; Esau, C.C.; Zdobnov, E.M.; et al. Integration of microRNA miR-122 in hepatic circadian gene expression. Genes Dev. 2009, 23, 1313-1326. [CrossRef]

348. Challet, E.; Denis, I.; Rochet, V.; Aioun, J.; Gourmelen, S.; Lacroix, H.; Goustard-Langelier, B.; Papillon, C.; Alessandri, J.M.; Lavialle, M. The role of PPARbeta/delta in the regulation of glutamatergic signaling in the hamster suprachiasmatic nucleus. Cell Mol. Life Sci. 2013, 70, 2003-2014. [CrossRef]

349. Anghel, S.I.; Wahli, W. Fat poetry: A kingdom for PPAR gamma. Cell Res. 2007, 17, 486-511. [CrossRef]

350. Lehmann, J.M.; Moore, L.B.; Smith-Oliver, T.A.; Wilkison, W.O.; Willson, T.M.; Kliewer, S.A. An antidiabetic thiazolidinedione is a high affinity ligand for peroxisome proliferator-activated receptor gamma (PPAR gamma). J. Biol. Chem. 1995, 270, 12953-12956. [CrossRef]

351. Imai, T.; Takakuwa, R.; Marchand, S.; Dentz, E.; Bornert, J.M.; Messaddeq, N.; Wendling, O.; Mark, M.; Desvergne, B.; Wahli, W.; et al. Peroxisome proliferator-activated receptor gamma is required in mature white and brown adipocytes for their survival in the mouse. Proc. Natl. Acad. Sci. USA 2004, 101, 4543-4547. [CrossRef] [PubMed]

352. Cerbone, A.; Toaldo, C.; Laurora, S.; Briatore, F.; Pizzimenti, S.; Dianzani, M.U.; Ferretti, C.; Barrera, G. 4-Hydroxynonenal and PPARgamma ligands affect proliferation, differentiation, and apoptosis in colon cancer cells. Free Radic. Biol. Med. 2007, 42, 1661-1670. [CrossRef] [PubMed]

353. Martinasso, G.; Oraldi, M.; Trombetta, A.; Maggiora, M.; Bertetto, O.; Canuto, R.A.; Muzio, G. Involvement of PPARs in cell proliferation and apoptosis in human colon cancer specimens and in normal and cancer cell lines. PPAR Res. 2007, 2007, 93416. [CrossRef] [PubMed]

354. Theocharis, S.; Margeli, A.; Vielh, P.; Kouraklis, G. Peroxisome proliferator-activated receptor-gamma ligands as cell-cycle modulators. Cancer Treat. Rev. 2004, 30, 545-554. [CrossRef] [PubMed]

355. Xu, W.P.; Zhang, X.; Xie, W.F. Differentiation therapy for solid tumors. J. Dig. Dis. 2014, 15, $159-165$. [CrossRef]

356. Chen, G.G.; Lee, J.F.; Wang, S.H.; Chan, U.P.; Ip, P.C.; Lau, W.Y. Apoptosis induced by activation of peroxisome-proliferator activated receptor-gamma is associated with Bcl-2 and NF-kappaB in human colon cancer. Life Sci. 2002, 70, 2631-2646. [CrossRef]

357. Sharma, C.; Pradeep, A.; Wong, L.; Rana, A.; Rana, B. Peroxisome proliferator-activated receptor gamma activation can regulate beta-catenin levels via a proteasome-mediated and adenomatous polyposis coli-independent pathway. J. Biol. Chem. 2004, 279, 35583-35594. [CrossRef]

358. Leonardini, A.; Laviola, L.; Perrini, S.; Natalicchio, A.; Giorgino, F. Cross-Talk between PPARgamma and Insulin Signaling and Modulation of Insulin Sensitivity. PPAR Res. 2009, 2009, 818945. [CrossRef]

359. Tontonoz, P.; Spiegelman, B.M. Fat and beyond: The diverse biology of PPARgamma. Annu. Rev. Biochem. 2008, 77, 289-312. [CrossRef]

360. Duszka, K.; Oresic, M.; Le May, C.; Konig, J.; Wahli, W. PPAR gamma modulates long chain fatty acid processing in the intestinal epithelium. Int. J. Mol. Sci. 2017, 18, 2559. [CrossRef] 
361. Duszka, K.; Picard, A.; Ellero-Simatos, S.; Chen, J.; Defernez, M.; Paramalingam, E.; Pigram, A.; Vanoaica, L.; Canlet, C.; Parini, P.; et al. Intestinal PPARgamma signalling is required for sympathetic nervous system activation in response to caloric restriction. Sci. Rep. 2016, 6, 36937. [CrossRef] [PubMed]

362. Soccio, R.E.; Chen, E.R.; Lazar, M.A. Thiazolidinediones and the promise of insulin sensitization in type 2 diabetes. Cell Metab. 2014, 20, 573-591. [CrossRef] [PubMed]

363. Henke, B.R. Peroxisome proliferator-activated receptor alpha/gamma dual agonists for the treatment of type 2 diabetes. J. Med. Chem. 2004, 47, 4118-4127. [CrossRef] [PubMed]

364. Kim, S.H.; Hong, S.H.; Park, Y.J.; Sung, J.H.; Suh, W.; Lee, K.W.; Jung, K.; Lim, C.; Kim, J.H.; Kim, H.; et al. MD001, a novel peroxisome proliferator-activated receptor alpha/gamma agonist, improves glucose and lipid metabolism. Sci. Rep. 2019, 9, 1656. [CrossRef] [PubMed]

365. Jain, M.R.; Giri, S.R.; Bhoi, B.; Trivedi, C.; Rath, A.; Rathod, R.; Ranvir, R.; Kadam, S.; Patel, H.; Swain, P.; et al. Dual PPARalpha/gamma agonist saroglitazar improves liver histopathology and biochemistry in experimental NASH models. Liver Int. 2018, 38, 1084-1094. [CrossRef] [PubMed]

366. Marion-Letellier, R.; Dechelotte, P.; Iacucci, M.; Ghosh, S. Dietary modulation of peroxisome proliferator-activated receptor gamma. Gut 2009, 58, 586-593. [CrossRef] [PubMed]

367. Schwab, M.; Reynders, V.; Loitsch, S.; Steinhilber, D.; Stein, J.; Schroder, O. Involvement of different nuclear hormone receptors in butyrate-mediated inhibition of inducible NF kappa B signalling. Mol. Immunol. 2007, 44, 3625-3632. [CrossRef]

368. Nepelska, M.; de Wouters, T.; Jacouton, E.; Beguet-Crespel, F.; Lapaque, N.; Dore, J.; Arulampalam, V.; Blottiere, H.M. Commensal gut bacteria modulate phosphorylation-dependent PPARgamma transcriptional activity in human intestinal epithelial cells. Sci. Rep. 2017, 7, 43199. [CrossRef]

369. Voltan, S.; Martines, D.; Elli, M.; Brun, P.; Longo, S.; Porzionato, A.; Macchi, V.; D’Inca, R.; Scarpa, M.; Palu, G.; et al. Lactobacillus crispatus M247-derived H2O2 acts as a signal transducing molecule activating peroxisome proliferator activated receptor-gamma in the intestinal mucosa. Gastroenterology 2008, 135, 1216-1227. [CrossRef]

370. Are, A.; Aronsson, L.; Wang, S.; Greicius, G.; Lee, Y.K.; Gustafsson, J.A.; Pettersson, S.; Arulampalam, V. Enterococcus faecalis from newborn babies regulate endogenous PPARgamma activity and IL-10 levels in colonic epithelial cells. Proc. Natl. Acad. Sci. USA 2008, 105, 1943-1948. [CrossRef]

371. Couvigny, B.; de Wouters, T.; Kaci, G.; Jacouton, E.; Delorme, C.; Dore, J.; Renault, P.; Blottiere, H.M.; Guedon, E.; Lapaque, N. Commensal streptococcus salivarius modulates PPAR gamma transcriptional activity in human intestinal epithelial cells. PLoS ONE 2015, 10, e0125371. [CrossRef] [PubMed]

372. Lu, M.; Sarruf, D.A.; Talukdar, S.; Sharma, S.; Li, P.; Bandyopadhyay, G.; Nalbandian, S.; Fan, W.; Gayen, J.R.; Mahata, S.K.; et al. Brain PPAR- $\gamma$ promotes obesity and is required for the insulin-sensitizing effect of thiazolidinediones. Nat. Med. 2011, 17, 618-622. [CrossRef] [PubMed]

373. Ryan, K.K.; Li, B.; Grayson, B.E.; Matter, E.K.; Woods, S.C.; Seeley, R.J. A role for central nervous system PPAR- $\gamma$ in the regulation of energy balance. Nat. Med. 2011, 17, 623-626. [CrossRef] [PubMed]

374. Koleva, D.I.; Orbetzova, M.M.; Atanassova, P.K. Adipose Tissue Hormones and Appetite and Body Weight Regulators an Insulin Resistance/Гормоны Жировой Ткани И РегуляторыАппетита И Массы Тела При Инсулиновой Резистентности. Folia Med. 2013, 55, 25-32. [CrossRef] [PubMed]

375. Adamo, K.B.; Dent, R.; Langefeld, C.D.; Cox, M.; Williams, K.; Carrick, K.M.; Stuart, J.S.; Sundseth, S.S.; Harper, M.E.; McPherson, R.; et al. Peroxisome proliferator-activated receptor gamma 2 and acyl-CoA synthetase 5 polymorphisms influence diet response. Obesity 2007, 15, 1068-1075. [CrossRef] [PubMed]

376. Matsuo, T.; Nakata, Y.; Katayama, Y.; Iemitsu, M.; Maeda, S.; Okura, T.; Kim, M.K.; Ohkubo, H.; Hotta, K.; Tanaka, K. PPARG genotype accounts for part of individual variation in body weight reduction in response to calorie restriction. Obesity 2009, 17, 1924-1931. [CrossRef]

377. Deeb, S.S.; Fajas, L.; Nemoto, M.; Pihlajamaki, J.; Mykkanen, L.; Kuusisto, J.; Laakso, M.; Fujimoto, W.; Auwerx, J. A Pro12Ala substitution in PPARgamma2 associated with decreased receptor activity, lower body mass index and improved insulin sensitivity. Nat. Genet. 1998, 20, 284-287. [CrossRef]

378. Masugi, J.; Tamori, Y.; Mori, H.; Koike, T.; Kasuga, M. Inhibitory effect of a proline-to-alanine substitution at codon 12 of peroxisome proliferator-activated receptor-gamma 2 on thiazolidinedione-induced adipogenesis. Biochem. Biophys. Res. Commun. 2000, 268, 178-182. [CrossRef] 
379. Nicklas, B.J.; van Rossum, E.F.; Berman, D.M.; Ryan, A.S.; Dennis, K.E.; Shuldiner, A.R. Genetic variation in the peroxisome proliferator-activated receptor-gamma2 gene (Pro12Ala) affects metabolic responses to weight loss and subsequent weight regain. Diabetes 2001, 50, 2172-2176. [CrossRef]

380. Memisoglu, A.; Hu, F.B.; Hankinson, S.E.; Manson, J.E.; De Vivo, I.; Willett, W.C.; Hunter, D.J. Interaction between a peroxisome proliferator-activated receptor gamma gene polymorphism and dietary fat intake in relation to body mass. Hum. Mol. Genet. 2003, 12, 2923-2929. [CrossRef]

381. Robitaille, J.; Despres, J.P.; Perusse, L.; Vohl, M.C. The PPAR-gamma P12A polymorphism modulates the relationship between dietary fat intake and components of the metabolic syndrome: Results from the Quebec Family Study. Clin. Genet. 2003, 63, 109-116. [CrossRef] [PubMed]

382. Luan, J.; Browne, P.O.; Harding, A.H.; Halsall, D.J.; O’Rahilly, S.; Chatterjee, V.K.; Wareham, N.J. Evidence for gene-nutrient interaction at the PPARgamma locus. Diabetes 2001, 50, 686-689. [CrossRef] [PubMed]

383. Lindi, V.; Schwab, U.; Louheranta, A.; Laakso, M.; Vessby, B.; Hermansen, K.; Storlien, L.; Riccardi, G.; Rivellese, A.A.; Matti, I.J. Impact of the Pro12Ala polymorphism of the PPAR-gamma2 gene on serum triacylglycerol response to n-3 fatty acid supplementation. Mol. Genet. Metab. 2003, 79, 52-60. [CrossRef]

384. Nolan, J.J.; Ludvik, B.; Beerdsen, P.; Joyce, M.; Olefsky, J. Improvement in glucose tolerance and insulin resistance in obese subjects treated with troglitazone. N. Engl. J. Med. 1994, 331, 1188-1193. [CrossRef] [PubMed]

385. Buchanan, T.A.; Xiang, A.H.; Peters, R.K.; Kjos, S.L.; Marroquin, A.; Goico, J.; Ochoa, C.; Tan, S.; Berkowitz, K.; Hodis, H.N.; et al. Preservation of pancreatic beta-cell function and prevention of type 2 diabetes by pharmacological treatment of insulin resistance in high-risk hispanic women. Diabetes 2002, 51, 2796-2803. [CrossRef] [PubMed]

386. Knowler, W.C.; Hamman, R.F.; Edelstein, S.L.; Barrett-Connor, E.; Ehrmann, D.A.; Walker, E.A.; Fowler, S.E.; Nathan, D.M.; Kahn, S.E.; Diabetes Prevention Program Research. Prevention of type 2 diabetes with troglitazone in the Diabetes Prevention Program. Diabetes 2005, 54, 1150-1156. [CrossRef]

387. Rocchi, S.; Picard, F.; Vamecq, J.; Gelman, L.; Potier, N.; Zeyer, D.; Dubuquoy, L.; Bac, P.; Champy, M.F.; Plunket, K.D.; et al. A unique PPAR gamma ligand with potent insulin-sensitizing yet weak adipogenic activity. Mol. Cell 2001, 8, 737-747. [CrossRef]

388. Dunn, F.L.; Higgins, L.S.; Fredrickson, J.; DePaoli, A.M.; INT131-004 Study Group. Selective modulation of PPARgamma activity can lower plasma glucose without typical thiazolidinedione side-effects in patients with Type 2 diabetes. J. Diabetes Complicat. 2011, 25, 151-158. [CrossRef]

389. Beekmann, K.; Rubio, L.; de Haan, L.H.; Actis-Goretta, L.; van der Burg, B.; van Bladeren, P.J.; Rietjens, I.M. The effect of quercetin and kaempferol aglycones and glucuronides on peroxisome proliferator-activated receptor-gamma (PPAR-gamma). Food Funct. 2015, 6, 1098-1107. [CrossRef]

390. Fang, X.K.; Gao, J.; Zhu, D.N. Kaempferol and quercetin isolated from Euonymus alatus improve glucose uptake of 3T3-L1 cells without adipogenesis activity. Life Sci. 2008, 82, 615-622. [CrossRef]

391. Moitra, J.; Mason, M.M.; Olive, M.; Krylov, D.; Gavrilova, O.; Marcus-Samuels, B.; Feigenbaum, L.; Lee, E.; Aoyama, T.; Eckhaus, M.; et al. Life without white fat: A transgenic mouse. Genes Dev. 1998, 12, 3168-3181. [CrossRef] [PubMed]

392. Reitman, M.L.; Arioglu, E.; Gavrilova, O.; Taylor, S.I. Lipoatrophy revisited. Trends Endocrinol. Metab. 2000, 11, 410-416. [CrossRef]

393. Larsen, T.M.; Toubro, S.; Astrup, A. PPARgamma agonists in the treatment of type II diabetes: Is increased fatness commensurate with long-term efficacy? Int. J. Obes. Relat. Metab. Disord. 2003, 27, 147-161. [CrossRef] [PubMed]

394. Ye, J.M.; Doyle, P.J.; Iglesias, M.A.; Watson, D.G.; Cooney, G.J.; Kraegen, E.W. Peroxisome proliferator-activated receptor (PPAR)-alpha activation lowers muscle lipids and improves insulin sensitivity in high fat-fed rats: Comparison with PPAR-gamma activation. Diabetes 2001, 50, 411-417. [CrossRef] [PubMed]

395. Agarwal, A.K.; Garg, A. A novel heterozygous mutation in peroxisome proliferator-activated receptor-gamma gene in a patient with familial partial lipodystrophy. J. Clin. Endocrinol. Metab. 2002, 87, 408-411. [CrossRef] [PubMed]

396. Hegele, R.A.; Cao, H.; Frankowski, C.; Mathews, S.T.; Leff, T. PPARG F388L, a transactivation-deficient mutant, in familial partial lipodystrophy. Diabetes 2002, 51, 3586-3590. [CrossRef] [PubMed] 
397. Demir, T.; Onay, H.; Savage, D.B.; Temeloglu, E.; Uzum, A.K.; Kadioglu, P.; Altay, C.; Ozen, S.; Demir, L.; Cavdar, U.; et al. Familial partial lipodystrophy linked to a novel peroxisome proliferator activator receptor -gamma (PPARG) mutation, H449L: A comparison of people with this mutation and those with classic codon 482 Lamin A/C (LMNA) mutations. Diabet Med. 2016, 33, 1445-1450. [CrossRef]

398. Ludtke, A.; Buettner, J.; Schmidt, H.H.; Worman, H.J. New PPARG mutation leads to lipodystrophy and loss of protein function that is partially restored by a synthetic ligand. J. Med. Genet. 2007, 44, e88. [CrossRef]

399. Ludtke, A.; Buettner, J.; Wu, W.; Muchir, A.; Schroeter, A.; Zinn-Justin, S.; Spuler, S.; Schmidt, H.H.; Worman, H.J. Peroxisome proliferator-activated receptor-gamma C190S mutation causes partial lipodystrophy. J. Clin. Endocrinol. Metab. 2007, 92, 2248-2255. [CrossRef]

400. Barroso, I.; Gurnell, M.; Crowley, V.E.; Agostini, M.; Schwabe, J.W.; Soos, M.A.; Maslen, G.L.; Williams, T.D.; Lewis, H.; Schafer, A.J.; et al. Dominant negative mutations in human PPARgamma associated with severe insulin resistance, diabetes mellitus and hypertension. Nature 1999, 402, 880-883. [CrossRef]

401. Savage, D.B.; Tan, G.D.; Acerini, C.L.; Jebb, S.A.; Agostini, M.; Gurnell, M.; Williams, R.L.; Umpleby, A.M.; Thomas, E.L.; Bell, J.D.; et al. Human metabolic syndrome resulting from dominant-negative mutations in the nuclear receptor peroxisome proliferator-activated receptor-gamma. Diabetes 2003, 52, 910-917. [CrossRef] [PubMed]

402. Collino, M.; Aragno, M.; Castiglia, S.; Miglio, G.; Tomasinelli, C.; Boccuzzi, G.; Thiemermann, C.; Fantozzi, R. Pioglitazone improves lipid and insulin levels in overweight rats on a high cholesterol and fructose diet by decreasing hepatic inflammation. Br. J. Pharmacol. 2010, 160, 1892-1902. [CrossRef] [PubMed]

403. Iwata, M.; Haruta, T.; Usui, I.; Takata, Y.; Takano, A.; Uno, T.; Kawahara, J.; Ueno, E.; Sasaoka, T.; Ishibashi, O.; et al. Pioglitazone ameliorates tumor necrosis factor-alpha-induced insulin resistance by a mechanism independent of adipogenic activity of peroxisome proliferator-activated receptor-gamma. Diabetes 2001, 50, 1083-1092. [CrossRef] [PubMed]

404. Smith, U.; Gogg, S.; Johansson, A.; Olausson, T.; Rotter, V.; Svalstedt, B. Thiazolidinediones (PPARgamma agonists) but not PPARalpha agonists increase IRS-2 gene expression in 3T3-L1 and human adipocytes. FASEB J. 2001, 15, 215-220. [CrossRef] [PubMed]

405. Rieusset, J.; Auwerx, J.; Vidal, H. Regulation of gene expression by activation of the peroxisome proliferator-activated receptor gamma with rosiglitazone (BRL 49653) in human adipocytes. Biochem. Biophys. Res. Commun. 1999, 265, 265-271. [CrossRef] [PubMed]

406. Baumann, C.A.; Chokshi, N.; Saltiel, A.R.; Ribon, V. Cloning and characterization of a functional peroxisome proliferator activator receptor-gamma-responsive element in the promoter of the CAP gene. J. Biol. Chem. 2000, 275, 9131-9135. [CrossRef]

407. Ribon, V.; Johnson, J.H.; Camp, H.S.; Saltiel, A.R. Thiazolidinediones and insulin resistance: Peroxisome proliferatoractivated receptor gamma activation stimulates expression of the CAP gene. Proc. Natl. Acad. Sci. USA 1998, 95, 14751-14756. [CrossRef]

408. Kramer, D.; Shapiro, R.; Adler, A.; Bush, E.; Rondinone, C.M. Insulin-sensitizing effect of rosiglitazone (BRL-49653) by regulation of glucose transporters in muscle and fat of Zucker rats. Metabolism 2001, 50, 1294-1300. [CrossRef]

409. Standaert, M.L.; Kanoh, Y.; Sajan, M.P.; Bandyopadhyay, G.; Farese, R.V. Cbl, IRS-1, and IRS-2 mediate effects of rosiglitazone on PI3K, PKC-lambda, and glucose transport in 3T3/L1 adipocytes. Endocrinology 2002, 143, 1705-1716. [CrossRef]

410. Kim, H.I.; Kim, J.W.; Kim, S.H.; Cha, J.Y.; Kim, K.S.; Ahn, Y.H. Identification and functional characterization of the peroxisomal proliferator response element in rat GLUT2 promoter. Diabetes 2000, 49, 1517-1524. [CrossRef]

411. Samaha, F.F.; Szapary, P.O.; Iqbal, N.; Williams, M.M.; Bloedon, L.T.; Kochar, A.; Wolfe, M.L.; Rader, D.J. Effects of rosiglitazone on lipids, adipokines, and inflammatory markers in nondiabetic patients with low high-density lipoprotein cholesterol and metabolic syndrome. Arterioscler. Thromb. Vasc. Biol. 2006, 26, 624-630. [CrossRef] [PubMed]

412. Szalkowski, D.; White-Carrington, S.; Berger, J.; Zhang, B. Antidiabetic thiazolidinediones block the inhibitory effect of tumor necrosis factor-alpha on differentiation, insulin-stimulated glucose uptake, and gene expression in 3T3-L1 cells. Endocrinology 1995, 136, 1474-1481. [CrossRef] [PubMed] 
413. Pajvani, U.B.; Hawkins, M.; Combs, T.P.; Rajala, M.W.; Doebber, T.; Berger, J.P.; Wagner, J.A.; Wu, M.; Knopps, A.; Xiang, A.H.; et al. Complex distribution, not absolute amount of adiponectin, correlates with thiazolidinedione-mediated improvement in insulin sensitivity. J. Biol. Chem. 2004, 279, 12152-12162. [CrossRef] [PubMed]

414. Yamauchi, T.; Kamon, J.; Waki, H.; Terauchi, Y.; Kubota, N.; Hara, K.; Mori, Y.; Ide, T.; Murakami, K.; Tsuboyama-Kasaoka, N.; et al. The fat-derived hormone adiponectin reverses insulin resistance associated with both lipoatrophy and obesity. Nat. Med. 2001, 7, 941-946. [CrossRef] [PubMed]

415. Panasyuk, G.; Espeillac, C.; Chauvin, C.; Pradelli, L.A.; Horie, Y.; Suzuki, A.; Annicotte, J.S.; Fajas, L.; Foretz, M.; Verdeguer, F.; et al. PPARgamma contributes to PKM2 and HK2 expression in fatty liver. Nat. Commun. 2012, 3, 672. [CrossRef]

416. Armoni, M.; Harel, C.; Karni, S.; Chen, H.; Bar-Yoseph, F.; Ver, M.R.; Quon, M.J.; Karnieli, E. FOXO1 represses peroxisome proliferator-activated receptor-gamma1 and -gamma2 gene promoters in primary adipocytes. A novel paradigm to increase insulin sensitivity. J. Biol. Chem. 2006, 281, 19881-19891. [CrossRef]

417. Fan, W.; Imamura, T.; Sonoda, N.; Sears, D.D.; Patsouris, D.; Kim, J.J.; Olefsky, J.M. FOXO1 transrepresses peroxisome proliferator-activated receptor gamma transactivation, coordinating an insulin-induced feed-forward response in adipocytes. J. Biol. Chem. 2009, 284, 12188-12197. [CrossRef]

418. Dowell, P.; Otto, T.C.; Adi, S.; Lane, M.D. Convergence of peroxisome proliferator-activated receptor gamma and Foxo1 signaling pathways. J. Biol. Chem. 2003, 278, 45485-45491. [CrossRef]

419. Zhang, Y.; Gu, M.; Cai, W.; Yu, L.; Feng, L.; Zhang, L.; Zang, Q.; Wang, Y.; Wang, D.; Chen, H.; et al. Dietary component isorhamnetin is a PPARgamma antagonist and ameliorates metabolic disorders induced by diet or leptin deficiency. Sci. Rep. 2016, 6, 19288. [CrossRef]

420. Yamauchi, T.; Waki, H.; Kamon, J.; Murakami, K.; Motojima, K.; Komeda, K.; Miki, H.; Kubota, N.; Terauchi, Y.; Tsuchida, A.; et al. Inhibition of RXR and PPARgamma ameliorates diet-induced obesity and type 2 diabetes. J. Clin. Investig. 2001, 108, 1001-1013. [CrossRef]

421. Kubota, N.; Terauchi, Y.; Miki, H.; Tamemoto, H.; Yamauchi, T.; Komeda, K.; Satoh, S.; Nakano, R.; Ishii, C.; Sugiyama, T.; et al. PPAR gamma mediates high-fat diet-induced adipocyte hypertrophy and insulin resistance. Mol. Cell 1999, 4, 597-609. [CrossRef]

422. Miles, P.D.; Barak, Y.; He, W.; Evans, R.M.; Olefsky, J.M. Improved insulin-sensitivity in mice heterozygous for PPAR-gamma deficiency. J. Clin. Investig. 2000, 105, 287-292. [CrossRef] [PubMed]

423. Heikkinen, S.; Argmann, C.; Feige, J.N.; Koutnikova, H.; Champy, M.F.; Dali-Youcef, N.; Schadt, E.E.; Laakso, M.; Auwerx, J. The Pro12Ala PPARgamma2 variant determines metabolism at the gene-environment interface. Cell Metab. 2009, 9, 88-98. [CrossRef] [PubMed]

424. Altshuler, D.; Hirschhorn, J.N.; Klannemark, M.; Lindgren, C.M.; Vohl, M.C.; Nemesh, J.; Lane, C.R.; Schaffner, S.F.; Bolk, S.; Brewer, C.; et al. The common PPARgamma Pro12Ala polymorphism is associated with decreased risk of type 2 diabetes. Nat. Genet. 2000, 26, 76-80. [CrossRef] [PubMed]

425. Picard, F.; Auwerx, J. PPAR(gamma) and glucose homeostasis. Annu. Rev. Nutr. 2002, 22, 167-197. [CrossRef] [PubMed]

426. Cho, H.J.; Park, J.; Lee, H.W.; Lee, Y.S.; Kim, J.B. Regulation of adipocyte differentiation and insulin action with rapamycin. Biochem. Biophys. Res. Commun. 2004, 321, 942-948. [CrossRef] [PubMed]

427. Gagnon, A.; Lau, S.; Sorisky, A. Rapamycin-sensitive phase of 3T3-L1 preadipocyte differentiation after clonal expansion. J. Cell Physiol. 2001, 189, 14-22. [CrossRef]

428. Polak, P.; Cybulski, N.; Feige, J.N.; Auwerx, J.; Ruegg, M.A.; Hall, M.N. Adipose-specific knockout of raptor results in lean mice with enhanced mitochondrial respiration. Cell Metab. 2008, 8, 399-410. [CrossRef]

429. Bell, A.; Grunder, L.; Sorisky, A. Rapamycin inhibits human adipocyte differentiation in primary culture. Obes. Res. 2000, 8, 249-254. [CrossRef]

430. Carnevalli, L.S.; Masuda, K.; Frigerio, F.; Le Bacquer, O.; Um, S.H.; Gandin, V.; Topisirovic, I.; Sonenberg, N.; Thomas, G.; Kozma, S.C. S6K1 plays a critical role in early adipocyte differentiation. Dev. Cell 2010, 18, 763-774. [CrossRef]

431. Blanchard, P.G.; Festuccia, W.T.; Houde, V.P.; St-Pierre, P.; Brule, S.; Turcotte, V.; Cote, M.; Bellmann, K.; Marette, A.; Deshaies, Y. Major involvement of mTOR in the PPARgamma-induced stimulation of adipose tissue lipid uptake and fat accretion. J. Lipid Res. 2012, 53, 1117-1125. [CrossRef] [PubMed] 
432. Koh, Y.K.; Lee, M.Y.; Kim, J.W.; Kim, M.; Moon, J.S.; Lee, Y.J.; Ahn, Y.H.; Kim, K.S. Lipin1 is a key factor for the maturation and maintenance of adipocytes in the regulatory network with CCAAT/enhancer-binding protein alpha and peroxisome proliferator-activated receptor gamma 2. J. Biol. Chem. 2008, 283, 34896-34906. [CrossRef] [PubMed]

433. Kim, H.E.; Bae, E.; Jeong, D.Y.; Kim, M.J.; Jin, W.J.; Park, S.W.; Han, G.S.; Carman, G.M.; Koh, E.; Kim, K.S. Lipin1 regulates PPARgamma transcriptional activity. Biochem. J. 2013, 453, 49-60. [CrossRef] [PubMed]

434. Finck, B.N.; Gropler, M.C.; Chen, Z.; Leone, T.C.; Croce, M.A.; Harris, T.E.; Lawrence, J.C., Jr.; Kelly, D.P. Lipin 1 is an inducible amplifier of the hepatic PGC-1alpha/PPARalpha regulatory pathway. Cell Metab. 2006, 4, 199-210. [CrossRef]

435. Kim, J.B.; Wright, H.M.; Wright, M.; Spiegelman, B.M. ADD1/SREBP1 activates PPARgamma through the production of endogenous ligand. Proc. Natl. Acad. Sci. USA 1998, 95, 4333-4337. [CrossRef]

436. Bakan, I.; Laplante, M. Connecting mTORC1 signaling to SREBP-1 activation. Curr. Opin Lipidol. 2012, 23, 226-234. [CrossRef]

437. Purnell, P.T.; Liu, S.C.; Cardiff, R.; Gregg, J. Induction of PPAR gamma signaling and autophagy as a mechanism mediating acquired rapamycin resistance in breast cancer models. Cancer Res. 2008, 68, 3210.

438. Assumpcao, J.A.F.; Magalhaes, K.G.; Correa, J.R. The role of ppargamma and autophagy in ros production, lipid droplets biogenesis and its involvement with colorectal cancer cells modulation. Cancer Cell. Int. 2017, 17, 82. [CrossRef]

439. Kang, J.H.; Chang, Y.C.; Maurizi, M.R. 4-O-carboxymethyl ascochlorin causes ER stress and induced autophagy in human hepatocellular carcinoma cells. J. Biol. Chem. 2012, 287, 15661-15671. [CrossRef]

440. Pellerito, O.; Notaro, A.; Sabella, S.; De Blasio, A.; Vento, R.; Calvaruso, G.; Giuliano, M. WIN induces apoptotic cell death in human colon cancer cells through a block of autophagic flux dependent on PPARgamma down-regulation. Apoptosis 2014, 19, 1029-1042. [CrossRef]

441. Weng, J.R.; Bai, L.Y.; Chiu, C.F.; Hu, J.L.; Chiu, S.J.; Wu, C.Y. Cucurbitane triterpenoid from momordica charantia induces apoptosis and autophagy in breast cancer cells, in part, through peroxisome proliferator-activated receptor gamma activation. Evid. Based Complement. Alternat. Med. 2013, 2013, 935675. [CrossRef] [PubMed]

442. Zhou, J.; Zhang, W.; Liang, B.; Casimiro, M.C.; Whitaker-Menezes, D.; Wang, M.; Lisanti, M.P.; Lanza-Jacoby, S.; Pestell, R.G.; Wang, C. PPARgamma activation induces autophagy in breast cancer cells. Int. J. Biochem. Cell Biol. 2009, 41, 2334-2342. [CrossRef] [PubMed]

443. Yan, S.; Yang, X.; Chen, T.; Xi, Z.; Jiang, X. The PPARgamma agonist Troglitazone induces autophagy, apoptosis and necroptosis in bladder cancer cells. Cancer Gene Ther. 2014, 21, 188-193. [CrossRef] [PubMed]

444. Cerquetti, L.; Sampaoli, C.; Amendola, D.; Bucci, B.; Masuelli, L.; Marchese, R.; Misiti, S.; De Venanzi, A.; Poggi, M.; Toscano, V.; et al. Rosiglitazone induces autophagy in H295R and cell cycle deregulation in SW13 adrenocortical cancer cells. Exp. Cell Res. 2011, 317, 1397-1410. [CrossRef]

445. Xu, F.; Li, J.; Ni, W.; Shen, Y.W.; Zhang, X.P. Peroxisome proliferator-activated receptor-gamma agonist 15d-prostaglandin $\mathrm{J} 2$ mediates neuronal autophagy after cerebral ischemia-reperfusion injury. PLoS ONE 2013, 8, e55080. [CrossRef]

446. Li, H.; Zhang, Q.; Yang, X.; Wang, L. PPAR-gamma agonist rosiglitazone reduces autophagy and promotes functional recovery in experimental traumaticspinal cord injury. Neurosci. Lett. 2017, 650, 89-96. [CrossRef] [PubMed]

447. Mahmood, D.F.; Jguirim-Souissi, I.; Khadija el, H.; Blondeau, N.; Diderot, V.; Amrani, S.; Slimane, M.N.; Syrovets, T.; Simmet, T.; Rouis, M. Peroxisome proliferator-activated receptor gamma induces apoptosis and inhibits autophagy of human monocyte-derived macrophages via induction of cathepsin L: Potential role in atherosclerosis. J. Biol. Chem. 2011, 286, 28858-28866. [CrossRef]

448. Lamontagne, J.; Pepin, E.; Peyot, M.L.; Joly, E.; Ruderman, N.B.; Poitout, V.; Madiraju, S.R.; Nolan, C.J.; Prentki, M. Pioglitazone acutely reduces insulin secretion and causes metabolic deceleration of the pancreatic beta-cell at submaximal glucose concentrations. Endocrinology 2009, 150, 3465-3474. [CrossRef]

449. Boyle, J.G.; Logan, P.J.; Ewart, M.A.; Reihill, J.A.; Ritchie, S.A.; Connell, J.M.; Cleland, S.J.; Salt, I.P. Rosiglitazone stimulates nitric oxide synthesis in human aortic endothelial cells via AMP-activated protein kinase. J. Biol. Chem. 2008, 283, 11210-11217. [CrossRef]

450. Ceolotto, G.; Gallo, A.; Papparella, I.; Franco, L.; Murphy, E.; Iori, E.; Pagnin, E.; Fadini, G.P.; Albiero, M.; Semplicini, A.; et al. Rosiglitazone reduces glucose-induced oxidative stress mediated by NAD(P)H oxidase via AMPK-dependent mechanism. Arterioscler. Thromb. Vasc. Biol. 2007, 27, 2627-2633. [CrossRef] 
451. Wang, L.; Yin, Y.; Hou, G.; Kang, J.; Wang, Q. Peroxisome Proliferator-Activated Receptor (PPAR gamma) Plays a Protective Role in Cigarette Smoking-Induced Inflammation via AMP-Activated Protein Kinase (AMPK) Signaling. Med. Sci. Monit. 2018, 24, 5168-5177. [CrossRef] [PubMed]

452. Sun, H.; Zhu, X.; Lin, W.; Zhou, Y.; Cai, W.; Qiu, L. Interactions of TLR4 and PPAR gamma, dependent on AMPK signalling pathway contribute to anti-inflammatory effects of vaccariae hypaphorine in endothelial cells. Cell Physiol. Biochem. 2017, 42, 1227-1239. [CrossRef] [PubMed]

453. Wang, X.; Zhou, L.; Shao, L.; Qian, L.; Fu, X.; Li, G.; Luo, T.; Gu, Y.; Li, F.; Li, J.; et al. Troglitazone acutely activates AMP-activated protein kinase and inhibits insulin secretion from beta cells. Life Sci. 2007, 81, 160-165. [CrossRef] [PubMed]

454. LeBrasseur, N.K.; Kelly, M.; Tsao, T.S.; Farmer, S.R.; Saha, A.K.; Ruderman, N.B.; Tomas, E. Thiazolidinediones can rapidly activate AMP-activated protein kinase in mammalian tissues. Am. J. Physiol. Endocrinol. Metab. 2006, 291, E175-E181. [CrossRef] [PubMed]

455. Shen, Z.; Liang, X.; Rogers, C.Q.; Rideout, D.; You, M. Involvement of adiponectin-SIRT1-AMPK signaling in the protective action of rosiglitazone against alcoholic fatty liver in mice. Am. J. Physiol. Gastrointest. Liver Physiol. 2010, 298, G364-G374. [CrossRef] [PubMed]

456. Saha, A.K.; Avilucea, P.R.; Ye, J.M.; Assifi, M.M.; Kraegen, E.W.; Ruderman, N.B. Pioglitazone treatment activates AMP-activated protein kinase in rat liver and adipose tissue in vivo. Biochem. Biophys. Res. Commun. 2004, 314, 580-585. [CrossRef] [PubMed]

457. Ye, J.M.; Dzamko, N.; Hoy, A.J.; Iglesias, M.A.; Kemp, B.; Kraegen, E. Rosiglitazone treatment enhances acute AMP-activated protein kinase-mediated muscle and adipose tissue glucose uptake in high-fat-fed rats. Diabetes 2006, 55, 2797-2804. [CrossRef]

458. Coletta, D.K.; Sriwijitkamol, A.; Wajcberg, E.; Tantiwong, P.; Li, M.; Prentki, M.; Madiraju, M.; Jenkinson, C.P.; Cersosimo, E.; Musi, N.; et al. Pioglitazone stimulates AMP-activated protein kinase signalling and increases the expression of genes involved in adiponectin signalling, mitochondrial function and fat oxidation in human skeletal muscle in vivo: A randomised trial. Diabetologia 2009, 52, 723-732. [CrossRef]

459. Xiao, X.; Su, G.; Brown, S.N.; Chen, L.; Ren, J.; Zhao, P. Peroxisome proliferator-activated receptors gamma and alpha agonists stimulate cardiac glucose uptake via activation of AMP-activated protein kinase. J. Nutr. Biochem. 2010, 21, 621-626. [CrossRef]

460. Zhang, F.; Dey, D.; Branstrom, R.; Forsberg, L.; Lu, M.; Zhang, Q.; Sjoholm, A. BLX-1002, a novel thiazolidinedione with no PPAR affinity, stimulates AMP-activated protein kinase activity, raises cytosolic $\mathrm{Ca}^{2+}$, and enhances glucose-stimulated insulin secretion in a PI3K-dependent manner. Am. J. Physiol. Cell Physiol. 2009, 296, C346-C354. [CrossRef]

461. Chang, T.J.; Chen, W.P.; Yang, C.; Lu, P.H.; Liang, Y.C.; Su, M.J.; Lee, S.C.; Chuang, L.M. Serine-385 phosphorylation of inwardly rectifying $\mathrm{K}+$ channel subunit (Kir6.2) by AMP-dependent protein kinase plays a key role in rosiglitazone-induced closure of the K(ATP) channel and insulin secretion in rats. Diabetologia 2009, 52, 1112-1121. [CrossRef] [PubMed]

462. Sozio, M.S.; Lu, C.; Zeng, Y.; Liangpunsakul, S.; Crabb, D.W. Activated AMPK inhibits PPAR-\{alpha\} and PPAR-\{gamma\} transcriptional activity in hepatoma cells. Am. J. Physiol. Gastrointest. Liver Physiol. 2011, 301, G739-G747. [CrossRef] [PubMed]

463. Han, L.; Zhou, R.; Niu, J.; McNutt, M.A.; Wang, P.; Tong, T. SIRT1 is regulated by a PPAR \{gamma\}-SIRT1 negative feedback loop associated with senescence. Nucleic Acids Res. 2010, 38, 7458-7471. [CrossRef] [PubMed]

464. Zhang, J.; Zhang, Y.; Xiao, F.; Liu, Y.; Wang, J.; Gao, H.; Rong, S.; Yao, Y.; Li, J.; Xu, G. The peroxisome proliferator-activated receptor gamma agonist pioglitazone prevents NF-kappaB activation in cisplatin nephrotoxicity through the reduction of p65 acetylation via the AMPK-SIRT1/p300 pathway. Biochem. Pharmacol. 2016, 101, 100-111. [CrossRef] [PubMed]

465. Picard, F.; Kurtev, M.; Chung, N.; Topark-Ngarm, A.; Senawong, T.; Machado De Oliveira, R.; Leid, M.; McBurney, M.W.; Guarente, L. Sirt1 promotes fat mobilization in white adipocytes by repressing PPAR-gamma. Nature 2004, 429, 771-776. [CrossRef] [PubMed]

466. Floyd, Z.E.; Wang, Z.Q.; Kilroy, G.; Cefalu, W.T. Modulation of peroxisome proliferator-activated receptor gamma stability and transcriptional activity in adipocytes by resveratrol. Metabolism 2008, 57, S32-S38. [CrossRef] [PubMed] 
467. Yu, C.; Markan, K.; Temple, K.A.; Deplewski, D.; Brady, M.J.; Cohen, R.N. The nuclear receptor corepressors NCoR and SMRT decrease peroxisome proliferator-activated receptor gamma transcriptional activity and repress 3T3-L1 adipogenesis. J. Biol. Chem. 2005, 280, 13600-13605. [CrossRef]

468. Wang, N.; Yang, G.; Jia, Z.; Zhang, H.; Aoyagi, T.; Soodvilai, S.; Symons, J.D.; Schnermann, J.B.; Gonzalez, F.J.; Litwin, S.E.; et al. Vascular PPARgamma controls circadian variation in blood pressure and heart rate through Bmal1. Cell Metab. 2008, 8, 482-491. [CrossRef]

469. Fontaine, C.; Dubois, G.; Duguay, Y.; Helledie, T.; Vu-Dac, N.; Gervois, P.; Soncin, F.; Mandrup, S.; Fruchart, J.C.; Fruchart-Najib, J.; et al. The orphan nuclear receptor Rev-Erbalpha is a peroxisome proliferator-activated receptor (PPAR) gamma target gene and promotes PPARgamma-induced adipocyte differentiation. J. Biol. Chem. 2003, 278, 37672-37680. [CrossRef]

470. Austin, S.; Medvedev, A.; Yan, Z.H.; Adachi, H.; Hirose, T.; Jetten, A.M. Induction of the nuclear orphan receptor RORgamma during adipocyte differentiation of D1 and 3T3-L1 cells. Cell Growth Differ. 1998, 9, 267-276.

471. Nakahata, Y.; Akashi, M.; Trcka, D.; Yasuda, A.; Takumi, T. The in vitro real-time oscillation monitoring system identifies potential entrainment factors for circadian clocks. BMC Mol. Biol. 2006, 7, 5. [CrossRef] [PubMed]

472. Yang, G.; Jia, Z.; Aoyagi, T.; McClain, D.; Mortensen, R.M.; Yang, T. Systemic PPARgamma deletion impairs circadian rhythms of behavior and metabolism. PLoS ONE 2012, 7, e38117. [CrossRef]

473. Anan, F.; Masaki, T.; Fukunaga, N.; Teshima, Y.; Iwao, T.; Kaneda, K.; Umeno, Y.; Okada, K.; Wakasugi, K.; Yonemochi, H.; et al. Pioglitazone shift circadian rhythm of blood pressure from non-dipper to dipper type in type 2 diabetes mellitus. Eur. J. Clin. Investig. 2007, 37, 709-714. [CrossRef] [PubMed]

474. Kumar Jha, P.; Challet, E.; Kalsbeek, A. Circadian rhythms in glucose and lipid metabolism in nocturnal and diurnal mammals. Mol. Cell Endocrinol 2015, 418, 74-88. [CrossRef]

475. Chawla, A.; Lazar, M.A. Induction of Rev-ErbA alpha, an orphan receptor encoded on the opposite strand of the alpha-thyroid hormone receptor gene, during adipocyte differentiation. J. Biol. Chem. 1993, 268, 16265-16269.

476. Cho, H.; Zhao, X.; Hatori, M.; Yu, R.T.; Barish, G.D.; Lam, M.T.; Chong, L.W.; DiTacchio, L.; Atkins, A.R.; Glass, C.K.; et al. Regulation of circadian behaviour and metabolism by REV-ERB-alpha and REV-ERB-beta. Nature 2012, 485, 123-127. [CrossRef]

477. Shimba, S.; Ishii, N.; Ohta, Y.; Ohno, T.; Watabe, Y.; Hayashi, M.; Wada, T.; Aoyagi, T.; Tezuka, M. Brain and muscle Arnt-like protein-1 (BMAL1), a component of the molecular clock, regulates adipogenesis. Proc. Natl. Acad. Sci. USA 2005, 102, 12071-12076. [CrossRef]

478. Guo, B.; Chatterjee, S.; Li, L.; Kim, J.M.; Lee, J.; Yechoor, V.K.; Minze, L.J.; Hsueh, W.; Ma, K. The clock gene, brain and muscle Arnt-like 1, regulates adipogenesis via Wnt signaling pathway. FASEB J. 2012, 26, 3453-3463. [CrossRef]

479. Douris, N.; Kojima, S.; Pan, X.; Lerch-Gaggl, A.F.; Duong, S.Q.; Hussain, M.M.; Green, C.B. Nocturnin regulates circadian trafficking of dietary lipid in intestinal enterocytes. Curr. Biol. 2011, 21, 1347-1355. [CrossRef]

480. Katewa, S.D.; Akagi, K.; Bose, N.; Rakshit, K.; Camarella, T.; Zheng, X.; Hall, D.; Davis, S.; Nelson, C.S.; Brem, R.B.; et al. Peripheral circadian clocks mediate dietary restriction-dependent changes in lifespan and fat metabolism in drosophila. Cell Metab. 2016, 23, 143-154. [CrossRef]

481. Eckel-Mahan, K.L.; Patel, V.R.; de Mateo, S.; Orozco-Solis, R.; Ceglia, N.J.; Sahar, S.; Dilag-Penilla, S.A.; Dyar, K.A.; Baldi, P.; Sassone-Corsi, P. Reprogramming of the circadian clock by nutritional challenge. Cell 2013, 155, 1464-1478. [CrossRef] [PubMed]

482. Murakami, M.; Tognini, P.; Liu, Y.; Eckel-Mahan, K.L.; Baldi, P.; Sassone-Corsi, P. Gut microbiota directs PPARgamma-driven reprogramming of the liver circadian clock by nutritional challenge. EMBO Rep. 2016, 17, 1292-1303. [CrossRef] [PubMed]

483. Merry, B.J. Molecular mechanisms linking calorie restriction and longevity. Int. J. Biochem. Cell Biol. 2002, 34, 1340-1354. [CrossRef]

484. Sanz, A.; Caro, P.; Ibanez, J.; Gomez, J.; Gredilla, R.; Barja, G. Dietary restriction at old age lowers mitochondrial oxygen radical production and leak at complex I and oxidative DNA damage in rat brain. J. Bioenerg. Biomembr. 2005, 37, 83-90. [CrossRef] [PubMed]

485. Yu, B.P. Aging and oxidative stress: Modulation by dietary restriction. Free Radic. Biol. Med. 1996, 21, 651-668. [CrossRef] 
486. Barja, G. Aging in vertebrates, and the effect of caloric restriction: A mitochondrial free radical production-DNA damage mechanism? Biol. Rev. Camb. Philos. Soc. 2004, 79, 235-251. [CrossRef] [PubMed]

487. Barja, G. Free radicals and aging. Trends Neurosci. 2004, 27, 595-600. [CrossRef]

488. Forster, M.J.; Sohal, B.H.; Sohal, R.S. Reversible effects of long-term caloric restriction on protein oxidative damage. J. Gerontol. A Biol. Sci. Med. Sci. 2000, 55, B522-B529. [CrossRef]

489. Lambert, A.J.; Merry, B.J. Lack of effect of caloric restriction on bioenergetics and reactive oxygen species production in intact rat hepatocytes. J. Gerontol. A Biol. Sci. Med. Sci. 2005, 60, 175-180. [CrossRef]

490. Lambert, A.J.; Portero-Otin, M.; Pamplona, R.; Merry, B.J. Effect of ageing and caloric restriction on specific markers of protein oxidative damage and membrane peroxidizability in rat liver mitochondria. Mech. Ageing Dev. 2004, 125, 529-538. [CrossRef]

491. Patel, S.A.; Velingkaar, N.S.; Kondratov, R.V. Transcriptional control of antioxidant defense by the circadian clock. Antioxid. Redox. Signal. 2014, 20, 2997-3006. [CrossRef] [PubMed]

492. Hardeland, R.; Coto-Montes, A.; Poeggeler, B. Circadian rhythms, oxidative stress, and antioxidative defense mechanisms. Chronobiol. Int. 2003, 20, 921-962. [CrossRef] [PubMed]

493. Tomas-Zapico, C.; Coto-Montes, A.; Martinez-Fraga, J.; Rodriguez-Colunga, M.J.; Tolivia, D. Effects of continuous light exposure on antioxidant enzymes, porphyric enzymes and cellular damage in the Harderian gland of the Syrian hamster. J. Pineal. Res. 2003, 34, 60-68. [CrossRef] [PubMed]

494. Singh, R.; Singh, R.K.; Tripathi, A.K.; Cornelissen, G.; Schwartzkopff, O.; Otsuka, K.; Halberg, F. Chronomics of circulating plasma lipid peroxides and anti-oxidant enzymes and other related molecules in cirrhosis of liver. In the memory of late Shri Chetan Singh. Biomed. Pharmacother. 2005, 59 (Suppl. S1), S229-S235. [CrossRef]

495. Sani, M.; Sebai, H.; Gadacha, W.; Boughattas, N.A.; Reinberg, A.; Mossadok, B.A. Catalase activity and rhythmic patterns in mouse brain, kidney and liver. Comp. Biochem. Physiol. B Biochem. Mol. Biol. 2006, 145, 331-337. [CrossRef] [PubMed]

496. Fanjul-Moles, M.L.; Prieto-Sagredo, J.; Lopez, D.S.; Bartolo-Orozco, R.; Cruz-Rosas, H. Crayfish Procambarus clarkii retina and nervous system exhibit antioxidant circadian rhythms coupled with metabolic and luminous daily cycles. Photochem. Photobiol. 2009, 85, 78-87. [CrossRef] [PubMed]

497. Kanabrocki, E.L.; Murray, D.; Hermida, R.C.; Scott, G.S.; Bremner, W.F.; Ryan, M.D.; Ayala, D.E.; Third, J.L.; Shirazi, P.; Nemchausky, B.A.; et al. Circadian variation in oxidative stress markers in healthy and type II diabetic men. Chronobiol. Int. 2002, 19, 423-439. [CrossRef] [PubMed]

498. Krishnan, N.; Davis, A.J.; Giebultowicz, J.M. Circadian regulation of response to oxidative stress in Drosophila melanogaster. Biochem. Biophys. Res. Commun. 2008, 374, 299-303. [CrossRef] [PubMed]

499. Lapenna, D.; De Gioia, S.; Mezzetti, A.; Porreca, E.; Ciofani, G.; Marzio, L.; Capani, F.; Di Ilio, C.; Cuccurullo, F. Circadian variations in antioxidant defences and lipid peroxidation in the rat heart. Free Radic. Res. Commun. 1992, 17, 187-194. [CrossRef] [PubMed]

500. Diaz-Munoz, M.; Hernandez-Munoz, R.; Suarez, J.; Chagoya de Sanchez, V. Day-night cycle of lipid peroxidation in rat cerebral cortex and their relationship to the glutathione cycle and superoxide dismutase activity. Neuroscience 1985, 16, 859-863. [CrossRef]

501. Martin, V.; Sainz, R.M.; Mayo, J.C.; Antolin, I.; Herrera, F.; Rodriguez, C. Daily rhythm of gene expression in rat superoxide dismutases. Endocr. Res. 2003, 29, 83-95. [CrossRef] [PubMed]

502. Jang, Y.S.; Lee, M.H.; Lee, S.H.; Bae, K. Cu/Zn superoxide dismutase is differentially regulated in period gene-mutant mice. Biochem. Biophys. Res. Commun. 2011, 409, 22-27. [CrossRef] [PubMed]

503. Baydas, G.; Gursu, M.F.; Yilmaz, S.; Canpolat, S.; Yasar, A.; Cikim, G.; Canatan, H. Daily rhythm of glutathione peroxidase activity, lipid peroxidation and glutathione levels in tissues of pinealectomized rats. Neurosci. Lett. 2002, 323, 195-198. [CrossRef]

504. Agapito, M.T.; Redondo, I.; Plaza, R.; Lopez-Burillo, S.; Recio, J.M.; Pablos, M.I. Relationships between melatonin, glutathione peroxidase, glutathione reductase, and catalase. Endogenous rhythms on cerebral cortex in Gallus domesticus. Adv. Exp. Med. Biol. 1999, 460, 377-381. [PubMed]

505. Coto-Montes, A.; Boga, J.A.; Tomas-Zapico, C.; Rodriguez-Colunga, M.J.; Martinez-Fraga, J.; Tolivia-Cadrecha, D.; Menendez, G.; Hardeland, R.; Tolivia, D. Physiological oxidative stress model: Syrian hamster Harderian gland-sex differences in antioxidant enzymes. Free Radic. Biol. Med. 2001, 30, 785-792. [CrossRef] 
506. Davies, M.H.; Bozigian, H.P.; Merrick, B.A.; Birt, D.F.; Schnell, R.C. Circadian variations in glutathione-S-transferase and glutathione peroxidase activities in the mouse. Toxicol. Lett. 1983, 19, 23-27. [CrossRef]

507. Jaeschke, H.; Wendel, A. Diurnal fluctuation and pharmacological alteration of mouse organ glutathione content. Biochem. Pharmacol. 1985, 34, 1029-1033. [CrossRef]

508. Maurice, D.V.; Lightsey, S.F.; Hsu, K.T.; Rhoades, J.F. Comparison of glutathione S-transferase activity in the rat and birds: Tissue distribution and rhythmicity in chicken (Gallus domesticus) liver. Comp. Biochem. Physiol. B 1991, 100, 471-474. [CrossRef]

509. Chakravarty, S.; Rizvi, S.I. Circadian modulation of human erythrocyte plasma membrane redox system by melatonin. Neurosci. Lett. 2012, 518, 32-35. [CrossRef]

510. Jung-Hynes, B.; Schmit, T.L.; Reagan-Shaw, S.R.; Siddiqui, I.A.; Mukhtar, H.; Ahmad, N. Melatonin, a novel Sirt1 inhibitor, imparts antiproliferative effects against prostate cancer in vitro in culture and in vivo in TRAMP model. J. Pineal. Res. 2011, 50, 140-149. [CrossRef]

511. Patterson, A.D.; Shah, Y.M.; Matsubara, T.; Krausz, K.W.; Gonzalez, F.J. Peroxisome proliferator-activated receptor alpha induction of uncoupling protein 2 protects against acetaminophen-induced liver toxicity. Hepatology 2012, 56, 281-290. [CrossRef] [PubMed]

512. Sekulic-Jablanovic, M.; Petkovic, V.; Wright, M.B.; Kucharava, K.; Huerzeler, N.; Levano, S.; Brand, Y.; Leitmeyer, K.; Glutz, A.; Bausch, A.; et al. Effects of peroxisome proliferator activated receptors (PPAR)-gamma and -alpha agonists on cochlear protection from oxidative stress. PLoS ONE 2017, 12, e0188596. [CrossRef] [PubMed]

513. Chung, S.S.; Kim, M.; Youn, B.S.; Lee, N.S.; Park, J.W.; Lee, I.K.; Lee, Y.S.; Kim, J.B.; Cho, Y.M.; Lee, H.K.; et al. Glutathione peroxidase 3 mediates the antioxidant effect of peroxisome proliferator-activated receptor gamma in human skeletal muscle cells. Mol. Cell Biol. 2009, 29, 20-30. [CrossRef] [PubMed]

514. Girnun, G.D.; Domann, F.E.; Moore, S.A.; Robbins, M.E. Identification of a functional peroxisome proliferator-activated receptor response element in the rat catalase promoter. Mol. Endocrinol. 2002, 16, 2793-2801. [CrossRef]

515. Okuno, Y.; Matsuda, M.; Miyata, Y.; Fukuhara, A.; Komuro, R.; Shimabukuro, M.; Shimomura, I. Human catalase gene is regulated by peroxisome proliferator activated receptor-gamma through a response element distinct from that of mouse. Endocr. J. 2010, 57, 303-309. [CrossRef]

516. Ding, G.; Fu, M.; Qin, Q.; Lewis, W.; Kim, H.W.; Fukai, T.; Bacanamwo, M.; Chen, Y.E.; Schneider, M.D.; Mangelsdorf, D.J.; et al. Cardiac peroxisome proliferator-activated receptor gamma is essential in protecting cardiomyocytes from oxidative damage. Cardiovasc. Res. 2007, 76, 269-279. [CrossRef]

517. Zhang, F.; Liu, F.; Yan, M.; Ji, H.; Hu, L.; Li, X.; Qian, J.; He, X.; Zhang, L.; Shen, A.; et al. Peroxisome proliferator-activated receptor-gamma agonists suppress iNOS expression induced by LPS in rat primary Schwann cells. J. Neuroimmunol. 2010, 218, 36-47. [CrossRef]

518. Vandewalle, B.; Moerman, E.; Lefebvre, B.; Defrance, F.; Gmyr, V.; Lukowiak, B.; Kerr Conte, J.; Pattou, F. PPARgamma-dependent and -independent effects of rosiglitazone on lipotoxic human pancreatic islets. Biochem. Biophys. Res. Commun. 2008, 366, 1096-1101. [CrossRef]

519. Kleinhenz, J.M.; Kleinhenz, D.J.; You, S.; Ritzenthaler, J.D.; Hansen, J.M.; Archer, D.R.; Sutliff, R.L.; Hart, C.M. Disruption of endothelial peroxisome proliferator-activated receptor-gamma reduces vascular nitric oxide production. Am. J. Physiol. Heart Circ. Physiol. 2009, 297, H1647-H1654. [CrossRef]

520. Ricote, M.; Li, A.C.; Willson, T.M.; Kelly, C.J.; Glass, C.K. The peroxisome proliferator-activated receptor-gamma is a negative regulator of macrophage activation. Nature 1998, 391, 79-82. [CrossRef]

521. Li, M.; Pascual, G.; Glass, C.K. Peroxisome proliferator-activated receptor gamma-dependent repression of the inducible nitric oxide synthase gene. Mol. Cell Biol. 2000, 20, 4699-4707. [CrossRef] [PubMed]

522. Chan, S.H.; Wu, K.L.; Kung, P.S.; Chan, J.Y. Oral intake of rosiglitazone promotes a central antihypertensive effect via upregulation of peroxisome proliferator-activated receptor-gamma and alleviation of oxidative stress in rostral ventrolateral medulla of spontaneously hypertensive rats. Hypertension 2010, 55, 1444-1453. [CrossRef] [PubMed]

523. Paradis, E.; Clavel, S.; Bouillaud, F.; Ricquier, D.; Richard, D. Uncoupling protein 2: A novel player in neuroprotection. Trends Mol. Med. 2003, 9, 522-525. [CrossRef] [PubMed]

524. Nagy, L.; Tontonoz, P.; Alvarez, J.G.; Chen, H.; Evans, R.M. Oxidized LDL regulates macrophage gene expression through ligand activation of PPAR gamma. Cell 1998, 93, 229-240. [CrossRef] 
525. Ishii, T.; Itoh, K.; Ruiz, E.; Leake, D.S.; Unoki, H.; Yamamoto, M.; Mann, G.E. Role of Nrf2 in the regulation of CD36 and stress protein expression in murine macrophages: Activation by oxidatively modified LDL and 4-hydroxynonenal. Circ. Res. 2004, 94, 609-616. [CrossRef] [PubMed]

526. Febbraio, M.; Hajjar, D.P.; Silverstein, R.L. CD36: A class B scavenger receptor involved in angiogenesis, atherosclerosis, inflammation, and lipid metabolism. J. Clin. Investig. 2001, 108, 785-791. [CrossRef] [PubMed]

527. Fuenzalida, K.; Quintanilla, R.; Ramos, P.; Piderit, D.; Fuentealba, R.A.; Martinez, G.; Inestrosa, N.C.; Bronfman, M. Peroxisome proliferator-activated receptor gamma up-regulates the Bcl-2 anti-apoptotic protein in neurons and induces mitochondrial stabilization and protection against oxidative stress and apoptosis. J. Biol. Chem. 2007, 282, 37006-37015. [CrossRef] [PubMed]

528. Ren, Y.; Sun, C.; Sun, Y.; Tan, H.; Wu, Y.; Cui, B.; Wu, Z. PPAR gamma protects cardiomyocytes against oxidative stress and apoptosis via Bcl-2 upregulation. Vascul. Pharmacol. 2009, 51, 169-174. [CrossRef] [PubMed]

529. Osburn, W.O.; Kensler, T.W. Nrf2 signaling: An adaptive response pathway for protection against environmental toxic insults. Mutat. Res. 2008, 659, 31-39. [CrossRef] [PubMed]

530. Cho, H.Y.; Gladwell, W.; Wang, X.; Chorley, B.; Bell, D.; Reddy, S.P.; Kleeberger, S.R. Nrf2-regulated PPAR \{gamma\} expression is critical to protection against acute lung injury in mice. Am. J. Respir. Crit. Care Med. 2010, 182, 170-182. [CrossRef]

531. Park, E.Y.; Cho, I.J.; Kim, S.G. Transactivation of the PPAR-responsive enhancer module in chemopreventive glutathione S-transferase gene by the peroxisome proliferator-activated receptor-gamma and retinoid $\mathrm{X}$ receptor heterodimer. Cancer Res. 2004, 64, 3701-3713. [CrossRef] [PubMed]

532. Huang, J.; Tabbi-Anneni, I.; Gunda, V.; Wang, L. Transcription factor Nrf2 regulates SHP and lipogenic gene expression in hepatic lipid metabolism. Am. J. Physiol. Gastrointest. Liver Physiol. 2010, 299, G1211-G1221. [CrossRef] [PubMed]

533. Pekovic-Vaughan, V.; Gibbs, J.; Yoshitane, H.; Yang, N.; Pathiranage, D.; Guo, B.; Sagami, A.; Taguchi, K.; Bechtold, D.; Loudon, A.; et al. The circadian clock regulates rhythmic activation of the NRF2/glutathione-mediated antioxidant defense pathway to modulate pulmonary fibrosis. Genes Dev. 2014, 28, 548-560. [CrossRef] [PubMed]

534. Froy, O.; Chapnik, N. Circadian oscillation of innate immunity components in mouse small intestine. Mol. Immunol. 2007, 44, 1954-1960. [CrossRef] [PubMed]

535. Arjona, A.; Sarkar, D.K. Circadian oscillations of clock genes, cytolytic factors, and cytokines in rat NK cells. J. Immunol. 2005, 174, 7618-7624. [CrossRef] [PubMed]

536. Arjona, A.; Sarkar, D.K. Evidence supporting a circadian control of natural killer cell function. Brain Behav. Immun. 2006, 20, 469-476. [CrossRef] [PubMed]

537. Arjona, A.; Boyadjieva, N.; Sarkar, D.K. Circadian rhythms of granzyme B, perforin, IFN-gamma, and NK cell cytolytic activity in the spleen: Effects of chronic ethanol. J. Immunol. 2004, 172, 2811-2817. [CrossRef]

538. Druzd, D.; Matveeva, O.; Ince, L.; Harrison, U.; He, W.; Schmal, C.; Herzel, H.; Tsang, A.H.; Kawakami, N.; Leliavski, A.; et al. Lymphocyte circadian clocks control lymph node trafficking and adaptive immune responses. Immunity 2017, 46, 120-132. [CrossRef]

539. Bellet, M.M.; Deriu, E.; Liu, J.Z.; Grimaldi, B.; Blaschitz, C.; Zeller, M.; Edwards, R.A.; Sahar, S.; Dandekar, S.; Baldi, P.; et al. Circadian clock regulates the host response to Salmonella. Proc. Natl. Acad. Sci. USA 2013, 110, 9897-9902. [CrossRef]

540. Kundu, P.; Ling, T.W.; Korecka, A.; Li, Y.; D’Arienzo, R.; Bunte, R.M.; Berger, T.; Arulampalam, V.; Chambon, P.; Mak, T.W.; et al. Absence of intestinal PPARgamma aggravates acute infectious colitis in mice through a lipocalin-2-dependent pathway. PLoS Pathog. 2014, 10, e1003887. [CrossRef]

541. Silver, A.C.; Arjona, A.; Walker, W.E.; Fikrig, E. The circadian clock controls toll-like receptor 9-mediated innate and adaptive immunity. Immunity 2012, 36, 251-261. [CrossRef] [PubMed]

542. Logan, R.W.; Arjona, A.; Sarkar, D.K. Role of sympathetic nervous system in the entrainment of circadian natural-killer cell function. Brain Behav. Immun. 2011, 25, 101-109. [CrossRef] [PubMed]

543. Nakamura, Y.; Ishimaru, K.; Tahara, Y.; Shibata, S.; Nakao, A. Disruption of the suprachiasmatic nucleus blunts a time of day-dependent variation in systemic anaphylactic reaction in mice. J. Immunol. Res. 2014, 2014, 474217. [CrossRef] [PubMed] 
544. Guerrero-Vargas, N.N.; Salgado-Delgado, R.; Basualdo Mdel, C.; Garcia, J.; Guzman-Ruiz, M.; Carrero, J.C.; Escobar, C.; Buijs, R.M. Reciprocal interaction between the suprachiasmatic nucleus and the immune system tunes down the inflammatory response to lipopolysaccharide. J. Neuroimmunol. 2014, 273, 22-30. [CrossRef] [PubMed]

545. Gibbs, J.; Ince, L.; Matthews, L.; Mei, J.; Bell, T.; Yang, N.; Saer, B.; Begley, N.; Poolman, T.; Pariollaud, M.; et al. An epithelial circadian clock controls pulmonary inflammation and glucocorticoid action. Nat. Med. 2014, 20,919-926. [CrossRef] [PubMed]

546. Adams, K.L.; Castanon-Cervantes, O.; Evans, J.A.; Davidson, A.J. Environmental circadian disruption elevates the IL-6 response to lipopolysaccharide in blood. J. Biol. Rhythms 2013, 28, 272-277. [CrossRef] [PubMed]

547. Guerrero-Vargas, N.N.; Guzman-Ruiz, M.; Fuentes, R.; Garcia, J.; Salgado-Delgado, R.; Basualdo Mdel, C.; Escobar, C.; Markus, R.P.; Buijs, R.M. Shift work in rats results in increased inflammatory response after lipopolysaccharide administration: A role for food consumption. J. Biol. Rhythms 2015, 30, 318-330. [CrossRef]

548. Stapleton, C.M.; Jaradat, M.; Dixon, D.; Kang, H.S.; Kim, S.C.; Liao, G.; Carey, M.A.; Cristiano, J.; Moorman, M.P.; Jetten, A.M. Enhanced susceptibility of staggerer (RORalphasg/sg) mice to lipopolysaccharide-induced lung inflammation. Am. J. Physiol. Lung Cell Mol. Physiol. 2005, 289, L144-L152. [CrossRef]

549. Arjona, A.; Sarkar, D.K. The circadian gene mPer2 regulates the daily rhythm of IFN-gamma. J. Interferon. Cytokine Res. 2006, 26, 645-649. [CrossRef]

550. Liu, J.; Malkani, G.; Shi, X.; Meyer, M.; Cunningham-Runddles, S.; Ma, X.; Sun, Z.S. The circadian clock Period 2 gene regulates gamma interferon production of NK cells in host response to lipopolysaccharide-induced endotoxic shock. Infect. Immun. 2006, 74, 4750-4756. [CrossRef]

551. Gibbs, J.E.; Blaikley, J.; Beesley, S.; Matthews, L.; Simpson, K.D.; Boyce, S.H.; Farrow, S.N.; Else, K.J.; Singh, D.; Ray, D.W.; et al. The nuclear receptor REV-ERBalpha mediates circadian regulation of innate immunity through selective regulation of inflammatory cytokines. Proc. Natl. Acad. Sci. USA 2012, 109, 582-587. [CrossRef] [PubMed]

552. Sato, S.; Sakurai, T.; Ogasawara, J.; Takahashi, M.; Izawa, T.; Imaizumi, K.; Taniguchi, N.; Ohno, H.; Kizaki, T. A circadian clock gene, Rev-erbalpha, modulates the inflammatory function of macrophages through the negative regulation of Ccl2 expression. J. Immunol. 2014, 192, 407-417. [CrossRef] [PubMed]

553. Nguyen, K.D.; Fentress, S.J.; Qiu, Y.; Yun, K.; Cox, J.S.; Chawla, A. Circadian gene Bmal1 regulates diurnal oscillations of Ly6C(hi) inflammatory monocytes. Science 2013, 341, 1483-1488. [CrossRef] [PubMed]

554. Huo, M.; Huang, Y.; Qu, D.; Zhang, H.; Wong, W.T.; Chawla, A.; Huang, Y.; Tian, X.Y. Myeloid Bmal1 deletion increases monocyte recruitment and worsens atherosclerosis. FASEB J. 2017, 31, 1097-1106. [CrossRef] [PubMed]

555. Dzhagalov, I.; Giguere, V.; He, Y.W. Lymphocyte development and function in the absence of retinoic acid-related orphan receptor alpha. J. Immunol. 2004, 173, 2952-2959. [CrossRef]

556. Narasimamurthy, R.; Hatori, M.; Nayak, S.K.; Liu, F.; Panda, S.; Verma, I.M. Circadian clock protein cryptochrome regulates the expression of proinflammatory cytokines. Proc. Natl. Acad. Sci. USA 2012, 109, 12662-12667. [CrossRef] [PubMed]

557. Spengler, M.L.; Kuropatwinski, K.K.; Comas, M.; Gasparian, A.V.; Fedtsova, N.; Gleiberman, A.S.; Gitlin, I.I.; Artemicheva, N.M.; Deluca, K.A.; Gudkov, A.V.; et al. Core circadian protein CLOCK is a positive regulator of NF-kappaB-mediated transcription. Proc. Natl. Acad. Sci. USA 2012, 109, E2457-E2465. [CrossRef]

558. Morgan, M.J.; Liu, Z.G. Crosstalk of reactive oxygen species and NF-kappaB signaling. Cell Res. 2011, 21, 103-115. [CrossRef]

559. Goto, M.; Katayama, K.I.; Shirakawa, F.; Tanaka, I. Involvement of NF-kappaB p50/p65 heterodimer in activation of the human pro-interleukin-1beta gene at two subregions of the upstream enhancer element. Cytokine 1999, 11, 16-28. [CrossRef]

560. Kim, H.J.; Kim, K.W.; Yu, B.P.; Chung, H.Y. The effect of age on cyclooxygenase-2 gene expression: NF-kappaB activation and IkappaBalpha degradation. Free Radic. Biol. Med. 2000, 28, 683-692. [CrossRef]

561. Libermann, T.A.; Baltimore, D. Activation of interleukin-6 gene expression through the NF-kappa B transcription factor. Mol. Cell Biol. 1990, 10, 2327-2334. [CrossRef] [PubMed] 
562. Yao, J.; Mackman, N.; Edgington, T.S.; Fan, S.T. Lipopolysaccharide induction of the tumor necrosis factor-alpha promoter in human monocytic cells. Regulation by Egr-1, c-Jun, and NF-kappaB transcription factors. J. Biol. Chem. 1997, 272, 17795-17801. [CrossRef] [PubMed]

563. Taylor, B.S.; de Vera, M.E.; Ganster, R.W.; Wang, Q.; Shapiro, R.A.; Morris, S.M., Jr.; Billiar, T.R.; Geller, D.A. Multiple NF-kappaB enhancer elements regulate cytokine induction of the human inducible nitric oxide synthase gene. J. Biol. Chem. 1998, 273, 15148-15156. [CrossRef] [PubMed]

564. Ricote, M.; Huang, J.; Fajas, L.; Li, A.; Welch, J.; Najib, J.; Witztum, J.L.; Auwerx, J.; Palinski, W.; Glass, C.K. Expression of the peroxisome proliferator-activated receptor gamma (PPARgamma) in human atherosclerosis and regulation in macrophages by colony stimulating factors and oxidized low density lipoprotein. Proc. Natl. Acad. Sci. USA 1998, 95, 7614-7619. [CrossRef] [PubMed]

565. Jiang, C.; Ting, A.T.; Seed, B. PPAR-gamma agonists inhibit production of monocyte inflammatory cytokines. Nature 1998, 391, 82-86. [CrossRef]

566. Okada, M.; Yan, S.F.; Pinsky, D.J. Peroxisome proliferator-activated receptor-gamma (PPAR-gamma) activation suppresses ischemic induction of Egr-1 and its inflammatory gene targets. FASEB J. 2002, 16, 1861-1868. [CrossRef]

567. Barbier, O.; Torra, I.P.; Duguay, Y.; Blanquart, C.; Fruchart, J.C.; Glineur, C.; Staels, B. Pleiotropic actions of peroxisome proliferator-activated receptors in lipid metabolism and atherosclerosis. Arterioscler. Thromb. Vasc. Biol. 2002, 22, 717-726. [CrossRef]

568. Narala, V.R.; Adapala, R.K.; Suresh, M.V.; Brock, T.G.; Peters-Golden, M.; Reddy, R.C. Leukotriene B4 is a physiologically relevant endogenous peroxisome proliferator-activated receptor-alpha agonist. J. Biol. Chem. 2010, 285, 22067-22074. [CrossRef]

569. Wahli, W.; Michalik, L. PPARs at the crossroads of lipid signaling and inflammation. Trends Endocrinol. Metab. 2012, 23, 351-363. [CrossRef]

570. Delerive, P.; De Bosscher, K.; Besnard, S.; Vanden Berghe, W.; Peters, J.M.; Gonzalez, F.J.; Fruchart, J.C.; Tedgui, A.; Haegeman, G.; Staels, B. Peroxisome proliferator-activated receptor alpha negatively regulates the vascular inflammatory gene response by negative cross-talk with transcription factors NF-kappa B and AP-1. J. Biol. Chem. 1999, 274, 32048-32054. [CrossRef]

571. Crisafulli, C.; Cuzzocrea, S. The role of endogenous and exogenous ligands for the peroxisome proliferator-activated receptor alpha (PPAR-alpha) in the regulation of inflammation in macrophages. Shock 2009, 32, 62-73. [CrossRef] [PubMed]

572. Benetti, E.; Mastrocola, R.; Rogazzo, M.; Chiazza, F.; Aragno, M.; Fantozzi, R.; Collino, M.; Minetto, M.A. High sugar intake and development of skeletal muscle insulin resistance and inflammation in mice: A protective role for PPAR- delta agonism. Mediat. Inflamm. 2013, 2013, 509502. [CrossRef] [PubMed]

573. Ding, G.; Cheng, L.; Qin, Q.; Frontin, S.; Yang, Q. PPARdelta modulates lipopolysaccharide-induced TNFalpha inflammation signaling in cultured cardiomyocytes. J. Mol. Cell Cardiol. 2006, 40, 821-828. [CrossRef] [PubMed]

574. Peters, J.M.; Hollingshead, H.E.; Gonzalez, F.J. Role of peroxisome-proliferator-activated receptor beta/delta (PPARbeta/delta) in gastrointestinal tract function and disease. Clin. Sci. 2008, 115, 107-127. [CrossRef] [PubMed]

575. Lewis, J.D.; Lichtenstein, G.R.; Deren, J.J.; Sands, B.E.; Hanauer, S.B.; Katz, J.A.; Lashner, B.; Present, D.H.; Chuai, S.; Ellenberg, J.H.; et al. Rosiglitazone for active ulcerative colitis: A randomized placebo-controlled trial. Gastroenterology 2008, 134, 688-695. [CrossRef] [PubMed]

576. Bassaganya-Riera, J.; Hontecillas, R. CLA and n-3 PUFA differentially modulate clinical activity and colonic PPAR-responsive gene expression in a pig model of experimental IBD. Clin. Nutr. 2006, 25, 454-465. [CrossRef]

577. Sanchez-Hidalgo, M.; Martin, A.R.; Villegas, I.; de la Lastra, C.A. Rosiglitazone, a PPARgamma ligand, modulates signal transduction pathways during the development of acute TNBS-induced colitis in rats. Eur. J. Pharm. 2007, 562, 247-258. [CrossRef]

578. Su, C.G.; Wen, X.; Bailey, S.T.; Jiang, W.; Rangwala, S.M.; Keilbaugh, S.A.; Flanigan, A.; Murthy, S.; Lazar, M.A.; $\mathrm{Wu}, \mathrm{G} . \mathrm{D}$. A novel therapy for colitis utilizing PPAR-gamma ligands to inhibit the epithelial inflammatory response. J. Clin. Investig. 1999, 104, 383-389. [CrossRef]

579. Michalik, L.; Wahli, W. PPARs mediate lipid signaling in inflammation and cancer. PPAR Res. 2008, 2008, 134059. [CrossRef] 
580. Wada, K.; Nakajima, A.; Blumberg, R.S. PPARgamma and inflammatory bowel disease: A new therapeutic target for ulcerative colitis and Crohn's disease. Trends Mol. Med. 2001, 7, 329-331. [CrossRef]

581. Chawla, A.; Barak, Y.; Nagy, L.; Liao, D.; Tontonoz, P.; Evans, R.M. PPAR-gamma dependent and independent effects on macrophage-gene expression in lipid metabolism and inflammation. Nat. Med. 2001, 7, 48-52. [CrossRef] [PubMed]

582. Odegaard, J.I.; Ricardo-Gonzalez, R.R.; Goforth, M.H.; Morel, C.R.; Subramanian, V.; Mukundan, L.; Red Eagle, A.; Vats, D.; Brombacher, F.; Ferrante, A.W.; et al. Macrophage-specific PPARgamma controls alternative activation and improves insulin resistance. Nature 2007, 447, 1116-1120. [CrossRef] [PubMed]

583. Bassaganya-Riera, J.; Reynolds, K.; Martino-Catt, S.; Cui, Y.; Hennighausen, L.; Gonzalez, F.; Rohrer, J.; Benninghoff, A.U.; Hontecillas, R. Activation of PPAR gamma and delta by conjugated linoleic acid mediates protection from experimental inflammatory bowel disease. Gastroenterology 2004, 127, 777-791. [CrossRef] [PubMed]

584. Klotz, L.; Schmidt, S.; Heun, R.; Klockgether, T.; Kolsch, H. Association of the PPARgamma gene polymorphism Pro12Ala with delayed onset of multiple sclerosis. Neurosci. Lett. 2009, 449, 81-83. [CrossRef] [PubMed]

585. Regieli, J.J.; Jukema, J.W.; Doevendans, P.A.; Zwinderman, A.H.; van der Graaf, Y.; Kastelein, J.J.; Grobbee, D.E. PPAR gamma variant influences angiographic outcome and 10-year cardiovascular risk in male symptomatic coronary artery disease patients. Diabetes Care 2009, 32, 839-844. [CrossRef] [PubMed]

586. Jiang, J.; Xie, Z.; Guo, J.; Wang, Y.; Liu, C.; Zhang, S.; Tang, W.; Chen, Y. Association of PPARG rs 1801282 C >G polymorphism with risk of colorectal cancer: From a case-control study to a meta-analysis. Oncotarget 2017, 8, 100558-100569. [CrossRef] [PubMed]

587. Lin, J.; Chen, Y.; Tang, W.F.; Liu, C.; Zhang, S.; Guo, Z.Q.; Chen, G.; Zheng, X.W. PPARG rs3856806 C>T Polymorphism Increased the Risk of Colorectal Cancer: A Case-Control Study in Eastern Chinese Han Population. Front. Oncol. 2019, 9, 63. [CrossRef]

588. Yasui, Y.; Hosokawa, M.; Sahara, T.; Suzuki, R.; Ohgiya, S.; Kohno, H.; Tanaka, T.; Miyashita, K. Bitter gourd seed fatty acid rich in 9c,11t,13t-conjugated linolenic acid induces apoptosis and up-regulates the GADD45, p53 and PPAR gamma in human colon cancer Caco-2 cells. Prostaglandins Leukot. Essent. Fatty Acids 2005, 73, 113-119. [CrossRef]

589. Akinyeke, T.O.; Stewart, L.V. Troglitazone suppresses c-Myc levels in human prostate cancer cells via a PPARgamma-independent mechanism. Cancer Biol. Ther. 2011, 11, 1046-1058. [CrossRef]

590. Subbaramaiah, K.; Lin, D.T.; Hart, J.C.; Dannenberg, A.J. Peroxisome proliferator-activated receptor gamma ligands suppress the transcriptional activation of cyclooxygenase-2. Evidence for involvement of activator protein-1 and CREB-binding protein/p300. J. Biol. Chem. 2001, 276, 12440-12448. [CrossRef]

591. Vandoros, G.P.; Konstantinopoulos, P.A.; Sotiropoulou-Bonikou, G.; Kominea, A.; Papachristou, G.I.; Karamouzis, M.V.; Gkermpesi, M.; Varakis, I.; Papavassiliou, A.G. PPAR-gamma is expressed and NF-kB pathway is activated and correlates positively with COX-2 expression in stromal myofibroblasts surrounding colon adenocarcinomas. J. Cancer Res. Clin. Oncol. 2006, 132, 76-84. [CrossRef] [PubMed]

592. Heneka, M.T.; Klockgether, T.; Feinstein, D.L. Peroxisome proliferator-activated receptor-gamma ligands reduce neuronal inducible nitric oxide synthase expression and cell death in vivo. J. Neurosci. 2000, 20, 6862-6867. [CrossRef] [PubMed]

593. Girnun, G.D.; Smith, W.M.; Drori, S.; Sarraf, P.; Mueller, E.; Eng, C.; Nambiar, P.; Rosenberg, D.W.; Bronson, R.T.; Edelmann, W.; et al. APC-dependent suppression of colon carcinogenesis by PPAR gamma. Proc. Natl. Acad. Sci. USA 2002, 99, 13771-13776. [CrossRef] [PubMed]

594. Fujisawa, T.; Nakajima, A.; Fujisawa, N.; Takahashi, H.; Ikeda, I.; Tomimoto, A.; Yonemitsu, K.; Nakajima, N.; Kudo, C.; Wada, K.; et al. Peroxisome proliferator-activated receptor gamma (PPAR gamma) suppresses colonic epithelial cell turnover and colon carcinogenesis through inhibition of the beta-catenin/T cell factor (TCF) pathway. J. Pharmacol. Sci. 2008, 106, 627-638. [CrossRef] [PubMed]

595. Ye, J. Regulation of PPARgamma function by TNF-alpha. Biochem. Biophys. Res. Commun. 2008, 374, 405-408. [CrossRef] [PubMed]

596. Napolitano, M.; Costa, L.; Palermo, R.; Giovenco, A.; Vacca, A.; Gulino, A. Protective effect of pioglitazone, a PPARgamma ligand, in a 3 nitropropionic acid model of Huntington's disease. Brain Res. Bull. 2011, 85, 231-237. [CrossRef] [PubMed] 
597. Levi, F.; Focan, C.; Karaboue, A.; de la Valette, V.; Focan-Henrard, D.; Baron, B.; Kreutz, F.; Giacchetti, S. Implications of circadian clocks for the rhythmic delivery of cancer therapeutics. Adv. Drug Deliv. Rev. 2007, 59, 1015-1035. [CrossRef]

598. Yamazaki, S.; Straume, M.; Tei, H.; Sakaki, Y.; Menaker, M.; Block, G.D. Effects of aging on central and peripheral mammalian clocks. Proc. Natl. Acad. Sci. USA 2002, 99, 10801-10806. [CrossRef]

599. Scarbrough, K.; Losee-Olson, S.; Wallen, E.P.; Turek, F.W. Aging and photoperiod affect entrainment and quantitative aspects of locomotor behavior in Syrian hamsters. Am. J. Physiol. 1997, 272, R1219-R1225. [CrossRef]

600. Gibson, E.M.; Williams, W.P., 3rd; Kriegsfeld, L.J. Aging in the circadian system: Considerations for health, disease prevention and longevity. Exp. Gerontol. 2009, 44, 51-56. [CrossRef]

601. Hofman, M.A.; Swaab, D.F. Living by the clock: The circadian pacemaker in older people. Ageing Res. Rev. 2006, 5, 33-51. [CrossRef] [PubMed]

602. Chang, H.C.; Guarente, L. SIRT1 mediates central circadian control in the SCN by a mechanism that decays with aging. Cell 2013, 153, 1448-1460. [CrossRef] [PubMed]

603. Sellix, M.T.; Evans, J.A.; Leise, T.L.; Castanon-Cervantes, O.; Hill, D.D.; DeLisser, P.; Block, G.D.; Menaker, M.; Davidson, A.J. Aging differentially affects the re-entrainment response of central and peripheral circadian oscillators. J. Neurosci. 2012, 32, 16193-16202. [CrossRef] [PubMed]

604. Zhang, Y.; Brainard, G.C.; Zee, P.C.; Pinto, L.H.; Takahashi, J.S.; Turek, F.W. Effects of aging on lens transmittance and retinal input to the suprachiasmatic nucleus in golden hamsters. Neurosci. Lett. 1998, 258, 167-170. [CrossRef]

605. Weinert, D. Age-dependent changes of the circadian system. Chronobiol. Int. 2000, 17, 261-283. [CrossRef] [PubMed]

606. Witting, W.; Mirmiran, M.; Bos, N.P.; Swaab, D.F. The effect of old age on the free-running period of circadian rhythms in rat. Chronobiol. Int. 1994, 11, 103-112. [CrossRef] [PubMed]

607. Duffy, J.F.; Zeitzer, J.M.; Rimmer, D.W.; Klerman, E.B.; Dijk, D.J.; Czeisler, C.A. Peak of circadian melatonin rhythm occurs later within the sleep of older subjects. Am. J. Physiol. Endocrinol. Metab. 2002, 282, E297-E303. [CrossRef] [PubMed]

608. Yoon, I.Y.; Kripke, D.F.; Elliott, J.A.; Youngstedt, S.D.; Rex, K.M.; Hauger, R.L. Age-related changes of circadian rhythms and sleep-wake cycles. J. Am. Geriatr. Soc. 2003, 51, 1085-1091. [CrossRef] [PubMed]

609. Kolker, D.E.; Fukuyama, H.; Huang, D.S.; Takahashi, J.S.; Horton, T.H.; Turek, F.W. Aging alters circadian and light-induced expression of clock genes in golden hamsters. J. Biol. Rhythms 2003, 18, 159-169. [CrossRef] [PubMed]

610. Lee, C.C. The circadian clock and tumor suppression by mammalian period genes. Methods Enzymol. 2005, 393, 852-861. [CrossRef] [PubMed]

611. Swindell, W.R. Gene expression profiling of long-lived dwarf mice: Longevity-associated genes and relationships with diet, gender and aging. BMC Genom. 2007, 8, 353. [CrossRef] [PubMed]

612. Hurd, M.W.; Ralph, M.R. The significance of circadian organization for longevity in the golden hamster. J. Biol. Rhythms 1998, 13, 430-436. [CrossRef] [PubMed]

613. Hurd, M.W.; Zimmer, K.A.; Lehman, M.N.; Ralph, M.R. Circadian locomotor rhythms in aged hamsters following suprachiasmatic transplant. Am. J. Physiol. 1995, 269, R958-R968. [CrossRef] [PubMed]

614. Li, H.; Satinoff, E. Fetal tissue containing the suprachiasmatic nucleus restores multiple circadian rhythms in old rats. Am. J. Physiol. 1998, 275, R1735-R1744. [CrossRef] [PubMed]

615. Penev, P.D.; Kolker, D.E.; Zee, P.C.; Turek, F.W. Chronic circadian desynchronization decreases the survival of animals with cardiomyopathic heart disease. Am. J. Physiol. 1998, 275, H2334-H2337. [CrossRef]

616. Viswanathan, N.; Davis, F.C. Suprachiasmatic nucleus grafts restore circadian function in aged hamsters. Brain Res. 1995, 686, 10-16. [CrossRef]

617. Van Reeth, O.; Zhang, Y.; Zee, P.C.; Turek, F.W. Grafting fetal suprachiasmatic nuclei in the hypothalamus of old hamsters restores responsiveness of the circadian clock to a phase shifting stimulus. Brain Res. 1994, 643, 338-342. [CrossRef]

618. Khan, S.; Duan, P.; Yao, L.; Hou, H. Shiftwork-mediated disruptions of circadian rhythms and sleep homeostasis cause serious health problems. Int. J. Genom. 2018, 2018, 8576890. [CrossRef] 
619. Solanas, G.; Peixoto, F.O.; Perdiguero, E.; Jardi, M.; Ruiz-Bonilla, V.; Datta, D.; Symeonidi, A.; Castellanos, A.; Welz, P.S.; Caballero, J.M.; et al. Aged stem cells reprogram their daily rhythmic functions to adapt to stress. Cell 2017, 170, 678-692.e620. [CrossRef]

620. Knight, J.A. The biochemistry of aging. Adv. Clin. Chem. 2000, 35, 1-62.

621. Park, S.Y.; Kim, Y.W.; Kim, J.E.; Kim, J.Y. Age-associated changes in fat metabolism in the rat and its relation to sympathetic activity. Life Sci. 2006, 79, 2228-2233. [CrossRef] [PubMed]

622. Petersen, K.F.; Befroy, D.; Dufour, S.; Dziura, J.; Ariyan, C.; Rothman, D.L.; DiPietro, L.; Cline, G.W.; Shulman, G.I. Mitochondrial dysfunction in the elderly: Possible role in insulin resistance. Science 2003, 300, 1140-1142. [CrossRef] [PubMed]

623. Kenyon, C. The plasticity of aging: Insights from long-lived mutants. Cell 2005, 120, 449-460. [CrossRef] [PubMed]

624. Siersbaek, R.; Nielsen, R.; Mandrup, S. PPARgamma in adipocyte differentiation and metabolism-novel insights from genome-wide studies. FEBS Lett. 2010, 584, 3242-3249. [CrossRef] [PubMed]

625. Chawla, A.; Schwarz, E.J.; Dimaculangan, D.D.; Lazar, M.A. Peroxisome proliferator-activated receptor (PPAR) gamma: Adipose-predominant expression and induction early in adipocyte differentiation. Endocrinology 1994, 135, 798-800. [CrossRef] [PubMed]

626. Tontonoz, P.; Hu, E.; Spiegelman, B.M. Stimulation of adipogenesis in fibroblasts by PPAR gamma 2, a lipid-activated transcription factor. Cell 1994, 79, 1147-1156. [CrossRef]

627. Argmann, C.; Dobrin, R.; Heikkinen, S.; Auburtin, A.; Pouilly, L.; Cock, T.A.; Koutnikova, H.; Zhu, J.; Schadt, E.E.; Auwerx, J. Ppargamma2 is a key driver of longevity in the mouse. PLoS Genet. 2009, 5, e1000752. [CrossRef]

628. Lee, C.K.; Allison, D.B.; Brand, J.; Weindruch, R.; Prolla, T.A. Transcriptional profiles associated with aging and middle age-onset caloric restriction in mouse hearts. Proc. Natl. Acad. Sci. USA 2002, 99, 14988-14993. [CrossRef]

629. Iemitsu, M.; Miyauchi, T.; Maeda, S.; Tanabe, T.; Takanashi, M.; Irukayama-Tomobe, Y.; Sakai, S.; Ohmori, H.; Matsuda, M.; Yamaguchi, I. Aging-induced decrease in the PPAR-alpha level in hearts is improved by exercise training. Am. J. Physiol. Heart Circ. Physiol. 2002, 283, H1750-H1760. [CrossRef]

630. Corton, J.C.; Brown-Borg, H.M. Peroxisome proliferator-activated receptor gamma coactivator 1 in caloric restriction and other models of longevity. J. Gerontol. A Biol. Sci. Med. Sci. 2005, 60, 1494-1509. [CrossRef]

631. Stauber, A.J.; Brown-Borg, H.; Liu, J.; Waalkes, M.P.; Laughter, A.; Staben, R.A.; Coley, J.C.; Swanson, C.; Voss, K.A.; Kopchick, J.J.; et al. Constitutive expression of peroxisome proliferator-activated receptor alpha-regulated genes in dwarf mice. Mol. Pharmacol. 2005, 67, 681-694. [CrossRef] [PubMed]

632. Olsson, B.; Bohlooly, Y.M.; Brusehed, O.; Isaksson, O.G.; Ahren, B.; Olofsson, S.O.; Oscarsson, J.; Tornell, J. Bovine growth hormone-transgenic mice have major alterations in hepatic expression of metabolic genes. Am. J. Physiol. Endocrinol. Metab. 2003, 285, E504-E511. [CrossRef] [PubMed]

633. Zhang, Y.; Xie, Y.; Berglund, E.D.; Coate, K.C.; He, T.T.; Katafuchi, T.; Xiao, G.; Potthoff, M.J.; Wei, W.; Wan, Y.; et al. The starvation hormone, fibroblast growth factor-21, extends lifespan in mice. Elife 2012, 1, e00065. [CrossRef] [PubMed]

634. Hirao, A.; Tahara, Y.; Kimura, I.; Shibata, S. A balanced diet is necessary for proper entrainment signals of the mouse liver clock. PLoS ONE 2009, 4, e6909. [CrossRef] [PubMed]

Publisher's Note: MDPI stays neutral with regard to jurisdictional claims in published maps and institutional affiliations.

(C) 2020 by the authors. Licensee MDPI, Basel, Switzerland. This article is an open access article distributed under the terms and conditions of the Creative Commons Attribution (CC BY) license (http://creativecommons.org/licenses/by/4.0/). 